Historic, archived document

Do not assume content reflects current scientific knowledge, policies, or practices. 



\section{NEW ANd RARE PLANTS AND BULBS}
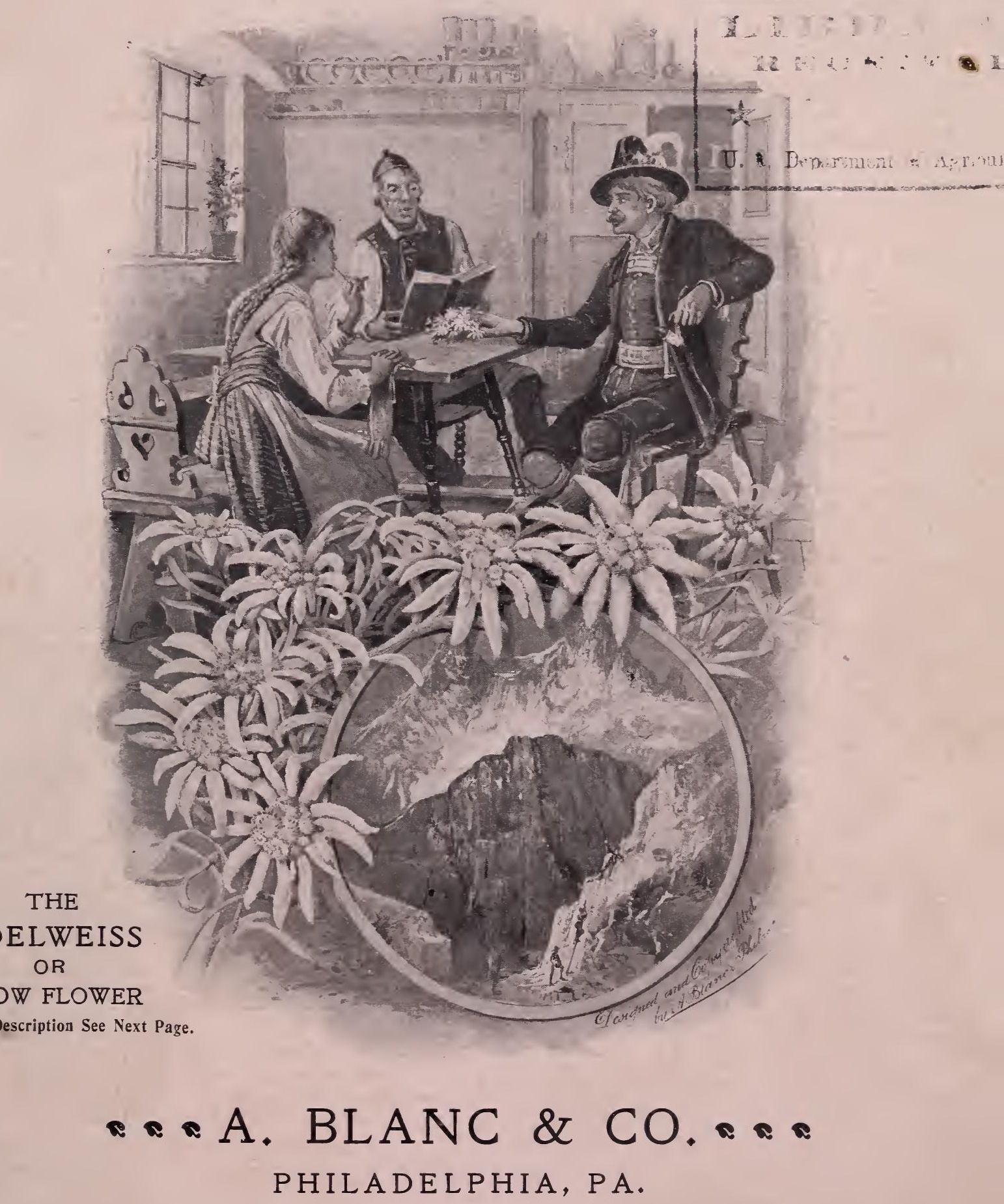


\section{A. BLANC \& CO., Philadelphia, catalogue of New and Rare Plants,}

This little catalogue is very unpretentious, but upon perusal our customers will notice that it contains more novelties of merit than can be found in many of the most expensive ones. We have merely to mention a few of them - such as Apera Arundinacea, Eurycles, Buddlia Variabilis, Campanula Mirabilis. Ceropegia Sandersoni, New Deutzias, Edelweiss. Two Incarvillias, New Hibiscus. 3 Kalanchoes, R. ew Hoya, Mitraria, Sidalcea, New Lupinus, Myosotis, Patchouli, New Amaryllis, New Cannas, and dozens of others. Of the norelties offered by the trade within the last few years, we claim to have introduced or popularized more than any other firm. Among these we may claim: Asparagus Sprengeri, Bougainvillea. Abutilon Savitzi. Astelbe Chinese, several new Clematises, Blue Spiraea, Crimson Spiraea, Crimson and White Ramblers, the new Sweet Briers, the Grand Italian Cannas, etc. WE GUARANTEE every article offered by us to arrive in good condition. We send everything by mail, postpaid, unless otherwise mentioned in catalogue, but we advise liberal orders to be sent by express, as we alwars add some new and valuable plants to more than compensate for the cost. Money may be sent in any way they please. whether by check, money older, stamps or bank notes. It is best to always register all letters containing currency or notes.

\section{THE FOLLOWING PUBLICATIONS MAY BE HAD OF US :}

CATALOGUE OF CACTI, beautifully illustrated, free. Of these we have the largest collection in the country.

HINTS ON CACTI, by A. Blanc. Acknowledged to be the best book on Cacti written in the English language; 100 pages, 100 cuts and a large colored plate. Price. $10 \mathrm{c}$.

LIST OF JAPANESE FLOWER POTS, Jardinieres,

Bowls, Vases, etc., made especially for us and imported direct from Japan. Offered at remarkably low prices.

A COLOR CHART.-A standard color chart. The most complete and the most accurate published ; 110 colors are represented and named. Substantially bound in board ALSO A MONTHLY BARGAIN LIST OF PLANTS, BULBS, ROOTS, ETC., AND SPECIAL LIST OF NOVELTIES.

EXTRA PREMIUMS.-Premium No. 1. - With an order to the amount of \$2 select extra plants or bulbs to the ralue of $\mathbf{2 5}$ cents; on a $\$ \mathbf{3}$ order $\mathbf{5 0}$ cents; on a $\mathbf{\$ 4}$ order $\mathbf{7 5}$ cents; on a $\mathbf{\$ 5}$ order $\mathbf{\$ 1}$, and so on, selecting 25 cents wortn of additional plants for every additional one dollar. Premium No. 2. - With an order amounting to $\mathbf{5 0}$ cents or over we send you free absolutely, five or more packets of some new and rare seeds. Premium No. 3. - Tie send you Due Bills for Plants with every order sent to us. Premium No. 4. $\$ 50$ for a new colored Zinnia. See $3 d$ page of corer.

\section{THF GENUINE IRISH SHAMROCK (Trifolium Minus)}

We were the first to introduce the seed of the GENUINE IRISH SHAMROCK in this country and have made it exceedingly popular. Thousands of plants are now handled by the florists, and it is becoming more popular erery year. Plants, 15c.; seed, 10c. pkt.

There's a dear little plant that grows on our isle,

'Twas St. Patrick himself sure that set it;

And the sun on his labor with pleasure did smile,

And the dew from his eyes oft did wet it.

\section{"THE EDELWEISS" \\ As White as Snow,}

No other flower in the whole unirerse, not eren the rarest Orchid, has cost so many lives as this chaste little Alpine Beauty. A recent publication states that "scores of lives" are lost annually by renturesome tourists in their efforts to obtain it. It is well-known that travelers circling the globe, will stop at the mountains of Switzerland and climb to almost inaccessible heights to be the proud possessors of the precious little treasure. It requiles patience, colirage,
strength, endurance, and a strength, endurance, and a therefore, that it is prized so highly ; that the ladies ornate their hats with it as trophies. No wonder that gathering the plants in their native home by crafty guides, who know their value, is now prohibited for fear of their extermination. Like the wonderful Rose of Jericho from Syria, and the Resurrer'ion Plant from Mexico, the JELWEISS, is a natural cr osity, for one may say, the "flower never dies."

It remains as white as the snow from which it sprung, and soft and velvety, even longer than Human Life.

There is some romance connected with it, also; it being an ancient local custom for the Tyrolian lover to present his affianced, as an engagement flower, one that he has gathered himself from amongst the snow-clad ocks, the higher the altitude, the more it is cherished.

It thrives through the bog, through the brake, through the mireland,

And he called it the dear little Shamrock of Ireiand : The sweet little shamrock, the dear little shamrock, The sweet little, dear little shamrock of Ireland.

\section{or Alpine Snowflower}

\section{but Lasts Forever.}

The flowers are certainly rare and beautiful, as white as snow and as soft as velvet, growing sometimes 30 on one plant, with grayish white foliage in spreading rosette. Naturally as hardy as a rock, they grow in any way, on sandy moist soil, gritty and well drained, or on raised rockwork, and even as a border plant, in chalky open soil. Lasting for years in beauty. it will certainly

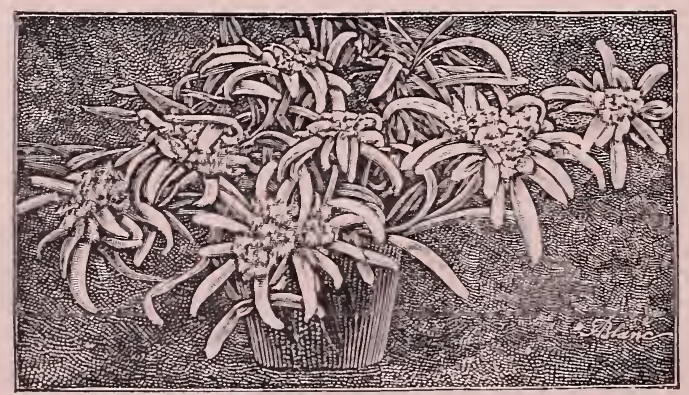
prove a wonderful attraction, aside from its intrinsic value, and the many ways which they can be used.

Glad are we, therefore, to be, we beliere, the first to offer in the United States thrifty live plants and flowers. It is well-known that oring to the scarcity of EDELWEISs flowers and the great demand for them, imitations made of white cloth, etc., are palmed off on credulous and uns s, phisticated travelers (German Exchange). Ours are genuine.

N. B.-A great department sture has just ordered 10,000 flowers of us-to trim "Alpine Hats."

Price of plants soon to bloom, 20c.; 3 for 50c.; seed, 10c. The Genuine Flowers last a lifetime; large specimens, 3 for 10 c.; 10 for 25 c.; 50 for $\$ 1$.

See illustration on cover page. 


\section{A 10,000 DOLLAR NOVELTY}

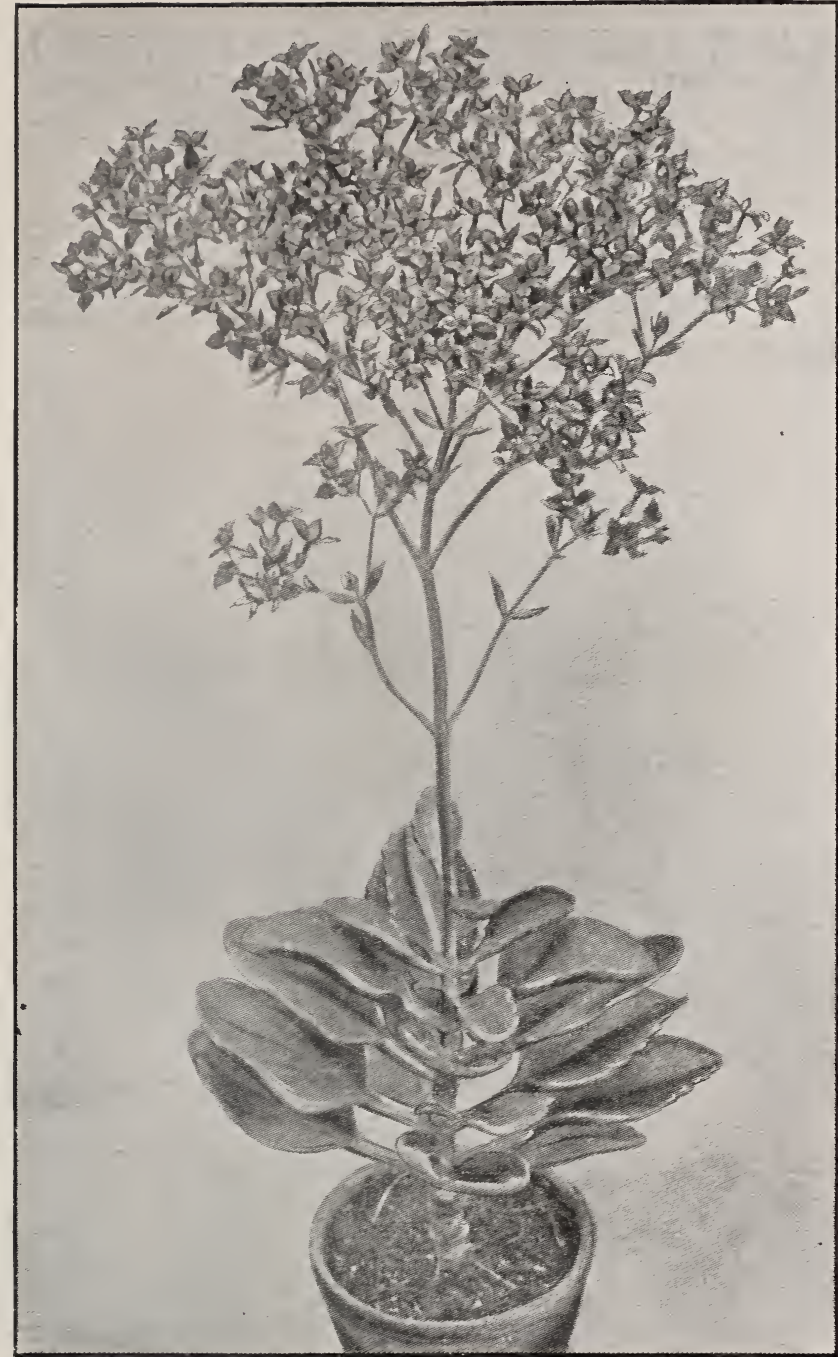

\section{NEW “KALANCHOE FLAMMEA." ‘ (TORCH LIGHT.)}

This grand new plant, introduced from Somaliland, in East Africa, by the Royal Gardens, Kew, where it flowered for the first time in 1897 , recently passed into the hands of a celebrated English firm, and we are the first to offer it in this country. The journals speak of it as a $\$ 10$,000 novelty, and, judging by the price asked for the seed $\left(62 \frac{1}{2} \mathrm{c}\right.$. per pkt.-more than 10 times its weight in diamonds) we should think so. It was awarded a first-class certificate by the Royal Horticultural Society, and a medal at Chiswick, and is spoken of by foreign journals as, "The best plant of all," "A most remarkable plant," "The best plant introduced for years," etc., etc. It bears fleshy pale green leaves. The flowers are carried on erect stems often $18 \mathrm{in}$. across. They are waxy and of a dazzling orange-scarlet, lasting at least a fortnight after cutting. One of the easiest plants to grow and bloom. Orders booked for plants as soon as ready at 50c. each. Seed 25c. per small pkt.

KALANCHOE CARNEA.

It is quite similar to the above valuable new plant. Its flowers, however, are a vivid golden yellow. In bloom the whole year and extremely handsome, leaves metallic purple. Fine plants ready now, 30c., cuttings $15 \mathrm{c}$. seed $10 \mathrm{c}$. per pkt.

New Kalanchoe Flammea.

\section{$\star$ KALANCHOE MARMORATA.} (QUEEN OF ABYSSINIA.)

TTe are pleased to be the first to offer this noble new plant in this country. All that can possibly be said of Kalanchoe Flammea applies to this, and no doubt it will be preferred by many. The leaves are silvery gray, 8 inches long, blotched especially underneath with bright purple. A single plant produces many flower spikes, measuring a foot to 18 inches across. Each flower is nearly four inches long and of the purest white. They last for a very long time and as soon as removed more flower spikes appear. One of the grandest shows ever seen. It was discovered in Abyssinia. Colorplated in the Botanical Magazine. No plant is easier to bloom or take care of. Fine plants $30 \mathrm{c}$. each, or with K. Carnea $50 \mathrm{c}$, , cuttings root casity $\frac{1}{2}$ price.

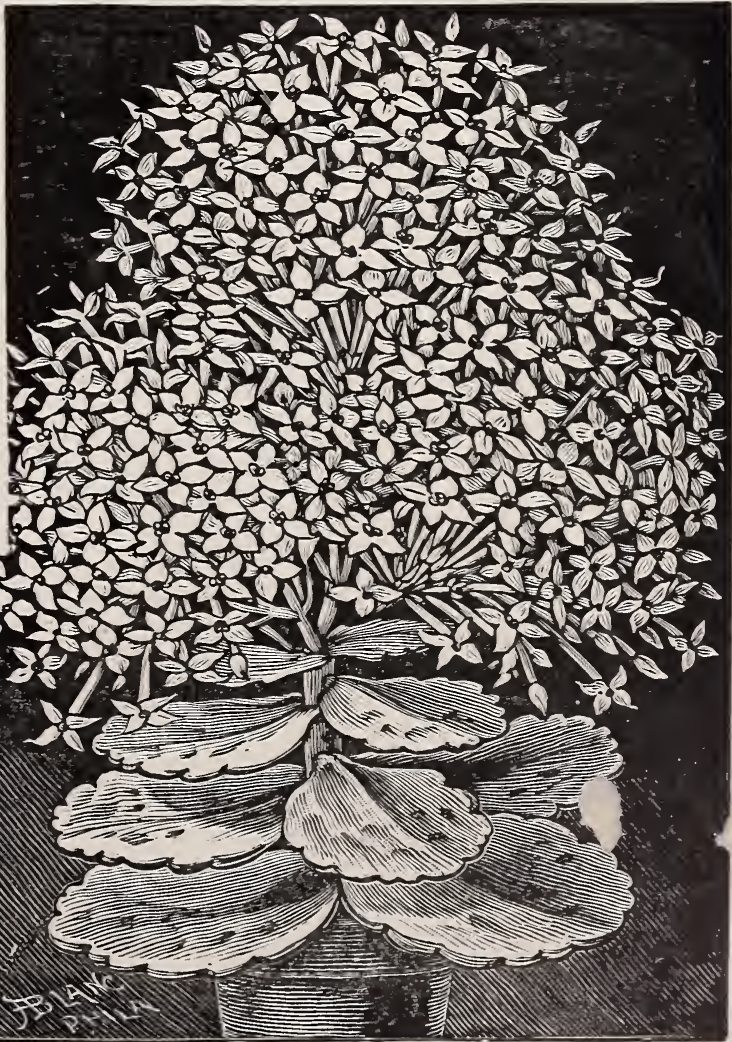

New Kalanchoe Marmorata. 


\section{$\star$ NEW WHITE CARYOPTERIS.}

"The Blue Caryopteris" or " Blue Spiræa," introduced by us some years ago, is now a permanent fixture in every garden. This new white flowering variety, which comes direct from China, should, by all means, be grown as a contrast. It forms grand beds in the garden and fine pot plants as well. Bees are very fond of them, and hundreds of them are often found frozen on the flower spikes late in the year; for let it be said that they are frequently blooming in December. They are both fine for cutting, and bloom well in the louse summer or winter. The foliage has a peculiar fragrance, agreeable to many persons. Both are excellent plants. Price, New White, 20 cts. Blue, 15 cts. Both for 30 cts. Seed, 10 cts.

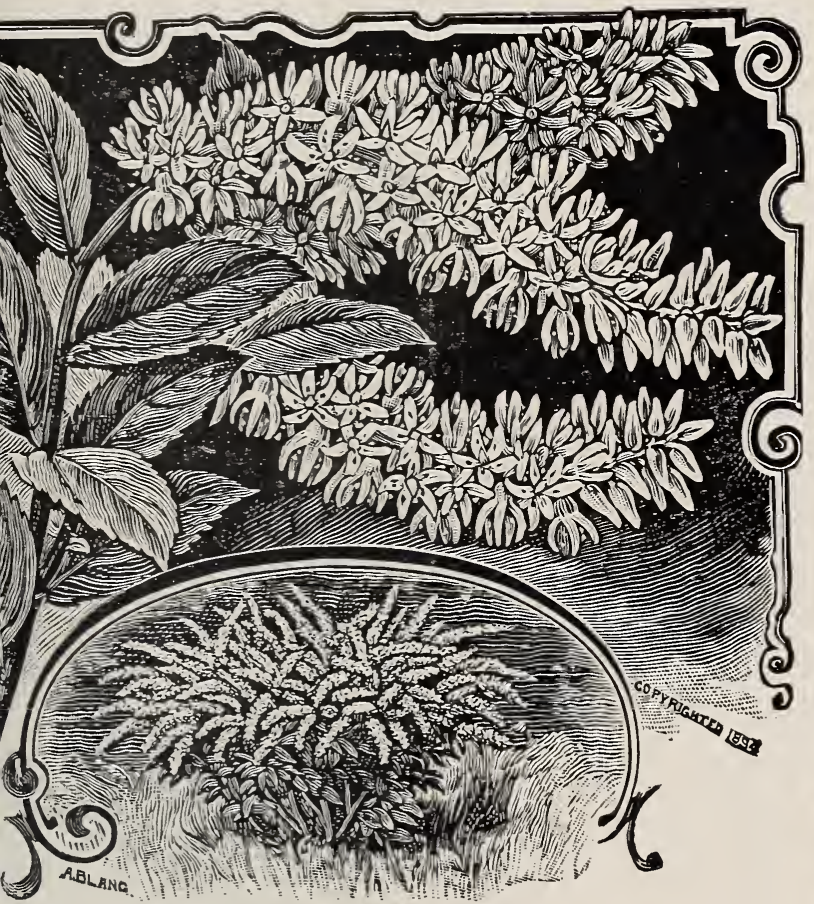

Buddleia Variabilis. Pride of China.

\section{$\star$ NEW BUDDLEIA VARIABILIS.}

(Pride of China).

A grand new shrub sent to Paris from China by the Abbe Soulie and exhibited at the National Horticultural Society, where it was greatly admired. It has been colored plated in all the prominent Horticultural journals, and spoken of as a valuable acquisition. It is a hardy shrub, growing 4 to 5 feet high, its gracefully arching branches covered with a woolly bloom. Leaves bright green above, velvety white below, producing a highly contrasting effect. The very numerous branches are terminated by long racemes of rosy lilac flowers, with an orange spot in the centre. Exquisite rose or violet shades have been produced on seedlings. Perfectly hardy, and first offered by us. Price, pot plants, 25 cts.; field clumps, 50 cts.; seed, 10 cts.

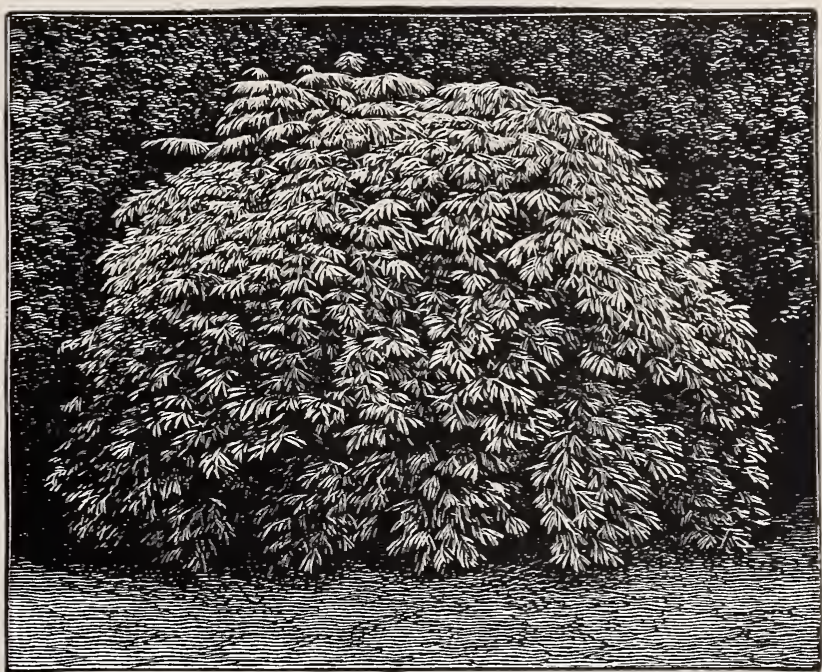

\section{NEW FEATHERED=LEAVED GOLDEN ELDER.}

(Sambucus racemosa plumosa foliis aureis), $九$.

An entirely distinct and new variety raised from the well-known golden Elder. The leaves of this free-growing sort are much more deeply cut, laciniated and fringed. The bright yellow color is perfectly constant, stands the full sun with impunity, and the leaves remain on the plant until late autumn. This, and the fact of its extreme hardiness, prove it a plant of the very greatest merit. The horticultural press has spoken of it as "one of the finest novelties offered for years."

Awarded Silver Medal, Ghent. Award of Merit, Royal Horticultural Society, London. First-class Certiflcate, P. S. Boskoop. First-class Certificate, Amsterdam. Its close, compact, symmetrical growth would makeit very available as a pot plant, Price, 40 cts.

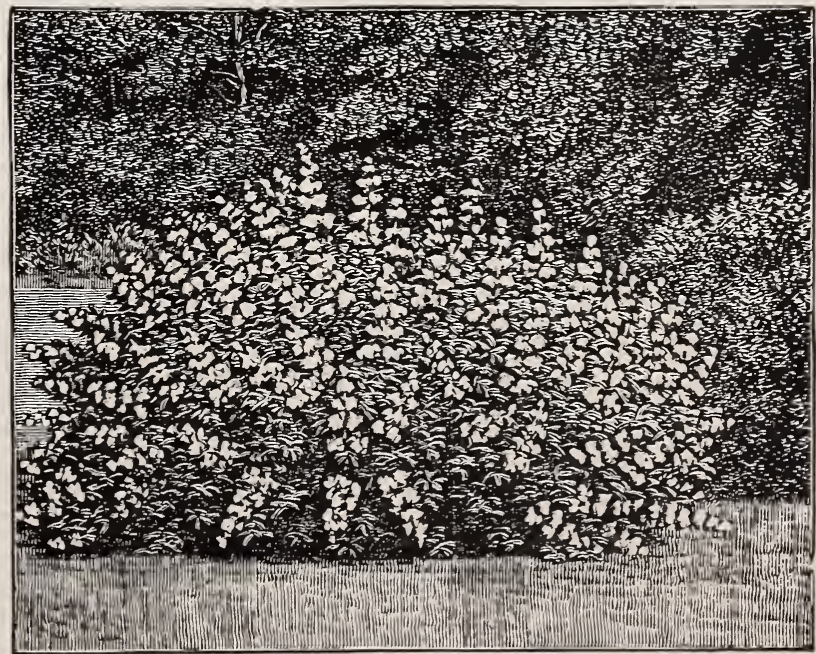

New White Caryopteris. 


\section{Some New Hardy Plants.}

\section{NEW SIDALCEA LISTERI-Pink Beauty.}

One of the finest hardy herbaceous plants introduced to the floral world. Its lovely colored spikes-a delicate satiny pink -borne on long stems, and flowering with continuous profusion from early June till November, make it a most desirable plant for every garden. Invaluable as a cut-flower, keeping fresh in water for days, likewise for border decoration, while for exhibition, hardly a more fetching spray could be shown. Awarded first-class certificates, Edinburgh, Rothesay, Clydebank; special silver medal, Wolverhampton; certificate of merit, R. H. S., London. Plants, 30 cents; seed, Io cents.

\section{NEW ASTILBE CHINENSE-The Pink Spiræa.}

Last year we received on order from a celebrated English

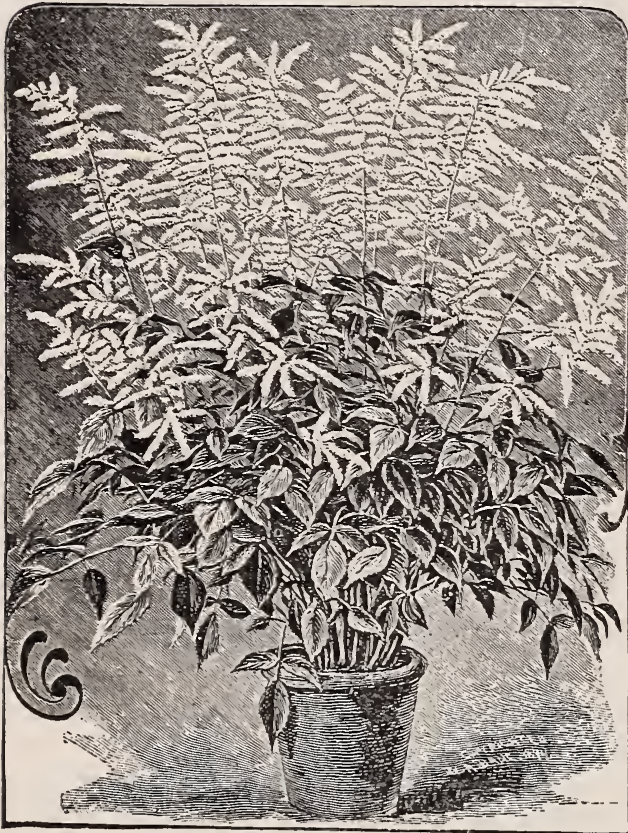

Astilbe Chinense. nursery for one thousand of these plants at any fair price. WVe forwarded 50, all that could be had and all that we would part with, so that we might have some for our customers. Such a large order should prove that it is a valuable novelty indeed, as foreign

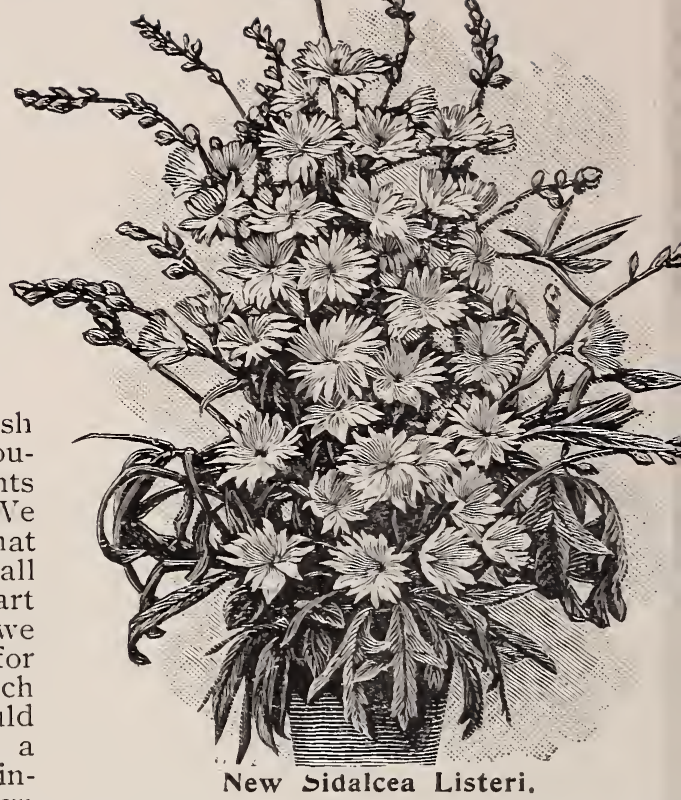
houses seldom order more than a few dozen of any plant. The plant has the same habit as the well-known Spiræa Japonica, with the exception that the flowers are of beautiful delicate rose; this alone makes it extremely valuable. It is one of the hardiest of garden plants, and also a good pot plant. Its extreme floriferousness will be appreciated. 30 cents.

\section{NEW DEUTZIA LEMOINEI.}

One of the most important new hardy plants offered in many years. It has the advantage over other Deutzias of having flowers nearly three times as large, produced in dense bouquets of 20 to 30 flowers each, and of the purest white. While also perfectly hardy, it is sure to be extensively grown by florists as an Easter plant, as it forces very readily. It has created quite a sensation wherever grown, and has been awarded certificates by the National Horticultural Society of France. Price for young plants, 25 cents.

We send these three novelties for 70 cents.

DRACAENA SANDERIANA.

A specimen of this exhibited at the World's Fair after travelling Io,000 miles was considered one of the wonders of the century. One thousand dollars would not have bought it. Large specimens make hundreds of stems closely set with leaves, which are almost white, faintly marked with light, silvery green. Young plants, 5o cents.

HOFFMANNIA REFULGENS.

Fine room plant, with very thick, velvety leaves of a rich brown, while underneath they are wine-colored; most grand and beautiful. Strong grower. 25 cents.

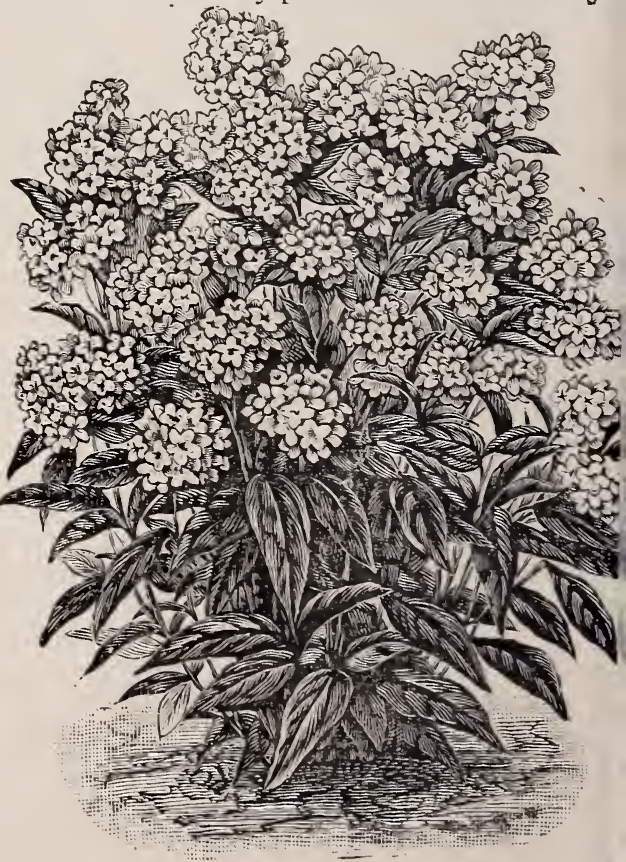

New Deutzia Lemoinei. 


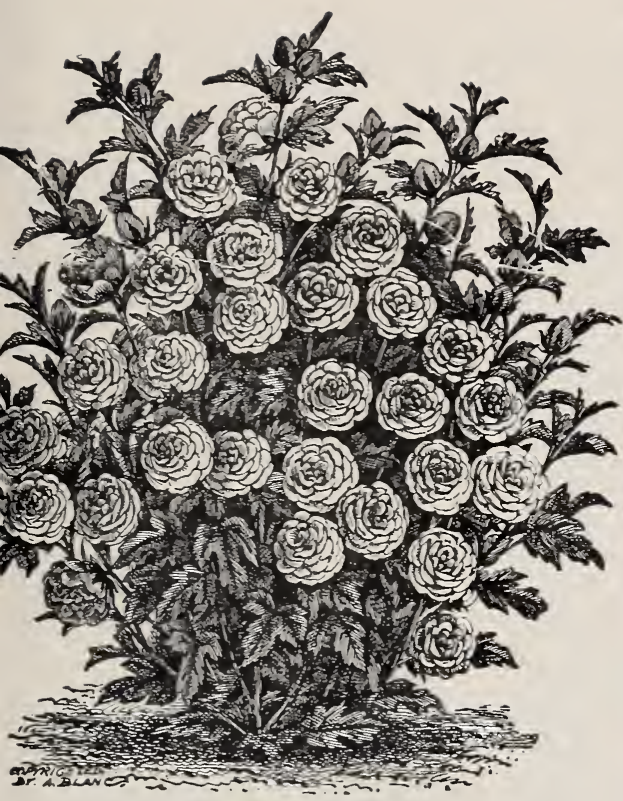

New Hibiscus "Joan of Arc."

Seldom, indeed, have new plants given us such delightful satisfaction as this new "Double Pure White Hardy Hibiscus.' Small plants in $2 \frac{1}{2}$-inch pots frequently carry 6 to 8 flowers open and many buds. These chaste flowers are borne during the entire season and even during winter in the house. Price 25 cts.

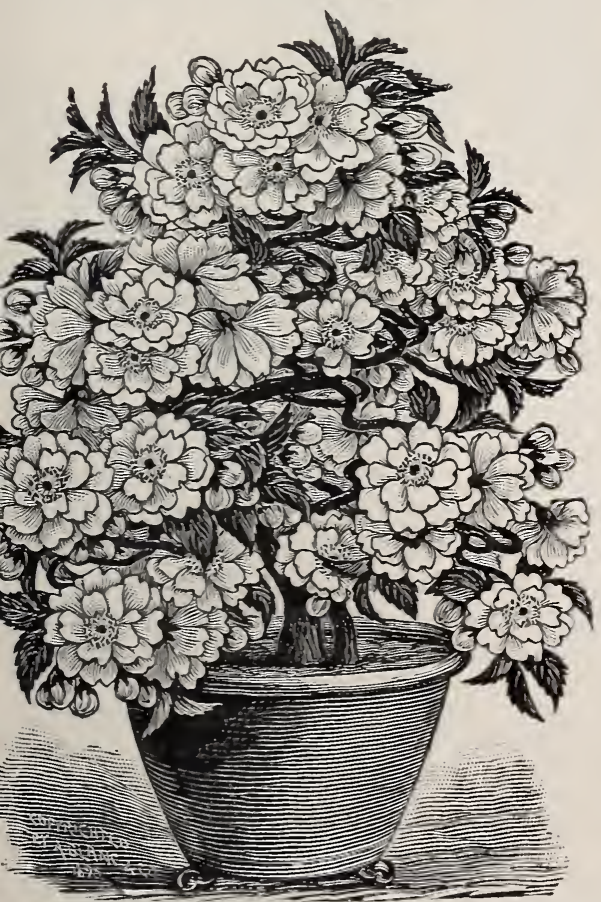

Japanese Dwarf Flowering Cherry. $\star$ NEW DEUTZIA CORYMBIFLORA (Snow in Summer)

\section{[From thie American Florist].}

This new Chinese Deutzia, introduced by Mr. de Vilmorin. in June it is covered with large white flowers, in clusters of from 30 to 40 , and in such a profusion that the shrub appears to be covered with snow. The appearance is equally as fine at the end of July as at the beginning of the following season. The shrub also flowers again in September, and the autumn, blooming has no bad effect on that of the following year. It has withstood two winters without killing back in the least. It is a novelty of sterling merit, and produces excellent effects either isolated on the lawn or planted in groups in front of larger shrubs in the border. Young plants 40 cts. each.

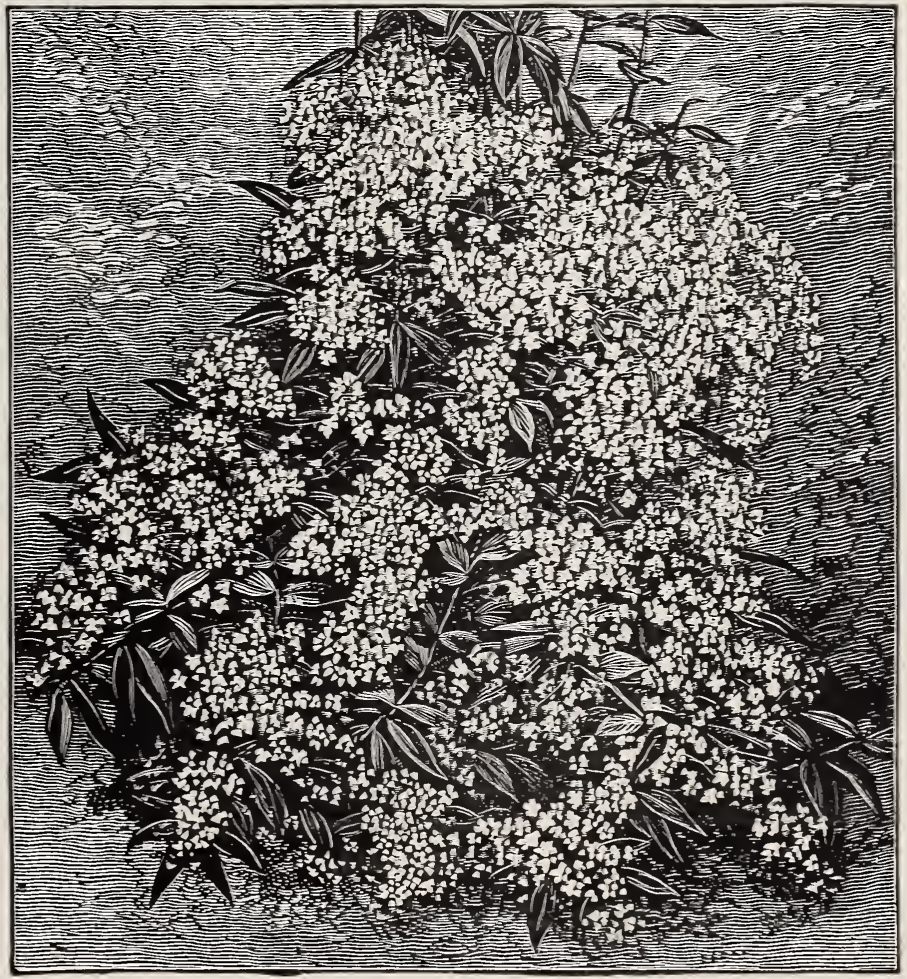

New Deutzia Corymbiflora "Snow in Summer."

\section{JAPANESE DWARF FLOWERING CHERRY.}

Nothing could be more beautiful than one of these little cherry trees in full bloom. They are artifically dwarfed and can be grown to perfection in a 6 -or 8-inch pot. If brought in the house or conservatory in gentle warmth, they will come in flower in two or three weeks. A succession of plants can be had in bloom for months. The flowers last for nearly two weeks after opening and are delightfully fragrant, very double, large, and shaded from white to pink. Eren branches cut off and placed in water will expand their buds. 60 cents each.

\section{t NEW DEUTZIA LEMOINEI COMPACTA}

The great value of "Deutzia Lemoinei" as a hardy garden shrub is now universally admitted. Our new introduction eclipses it in every way. Its dwarfer and more graceful habit -its clusters of larger and white flowers-could not possibly be improved upon, and will, no doubt, make it extremely popular as soon as it becomes disseminated especially as a pot plant. $40 \mathrm{cts}$. 


\section{Large=flowering Hardy Clematises.}

Our Clematises have given so much satisfaction in previous years that we devote more space to them than before. They are grown for us by Mr. Albert Knapper, a Clematis specialist, who grows them on their

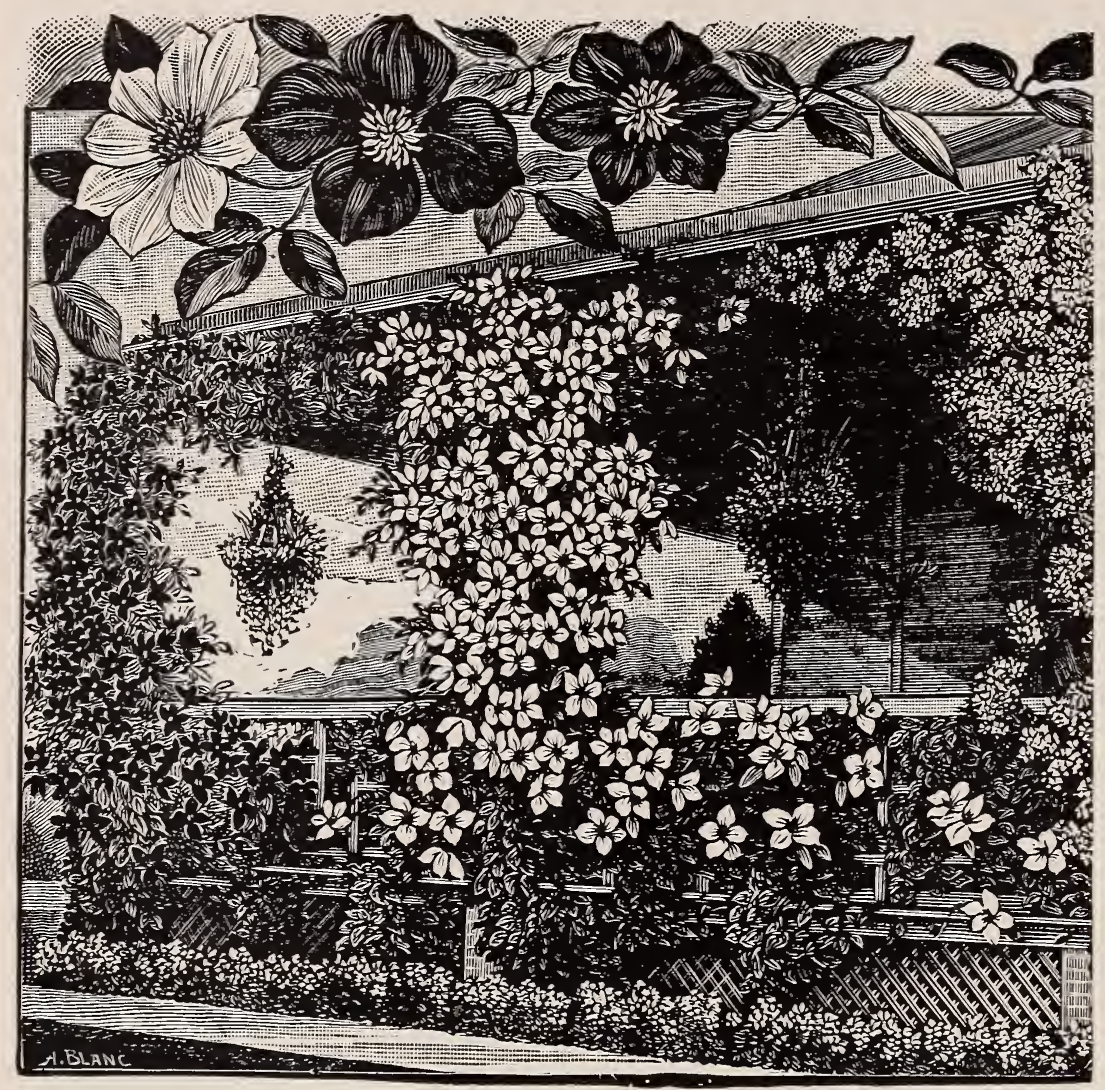

Clematis. own roots, and thus ensures plants that will liz'e. Most Clematises sold are grafted plants, only a small majority of which ever thrive more than one season. They should not be set out before May.

The following are considered by Mr. Knapper as the best and most distinct of some 40 varieties grown by him.

New CRIMSON Clematis, Mme. Edouard André. The only Clematis with large, velvety, deep crimson flowers, so profuse in bloom as to almost hide the foliage. The greatest and latest acquisition among Clematises, and not approached by any other.

New PINK Clematis, Mme. Baron Veillard. - The nearest approach to a pink and also unlike any other. Large, free-blooming, healthy grower, perfectly hardy, anci a most beautiful plant.

ALEXANDRIA.-A fine very large single flower of the deepest purple, and one of the very best.

André Leroy.-Large single flowers of a delicate palc lilac; too pretty and distinct to be omitted from a collection.

Belle of Woking.-Flowers very full and double; a hundred petals; color pure purple; free and constant bloomer; extra fine.

Duchess of Edinburgh. - The best of all the double whites; extremely profuse and fine bloomer; flowers delightfully fragrant.

Jackmanni.-Enormous flowers of rich violet-purple; one of the freest bloomers and best growers; the kind frequently seen on porches and verandas.

Henryi.-Large pure white flowers, with broad sepals and rose filaments. Another very free bloomer needed for contrast with others.

Mme. Granger.-Very distinct flowers of a crimson-violet, with pink stripes.

Sieboldi.-A most magnificent kind, with immense flowers of pure lavender; very broad substantial sepals, overlapping each other. Flowers last for a very long time even when cut. Can be highly recommended. Any of the above Clematises in $I=y$ ear=old plants at 30 cents each, 5 for $\$ 1.20$, or the 10 for $\$ 2.25$.

A YELLOW=FLOWERED CLEMATIS.-Clematis Graveolens is a quite rare Clematis, and certainly a very distinct sort. It is perfectly hardy, a fine climber, and bears dense clusters of pale yellow flowers. Nice young plants, 25 cents ; larger, 50 cents.

CLEMATIS PANICULATA.-One of the grandest climbing plants for all garden purposes; whell two or three years old it will cover a very large space, and will be perfectly zohite with clusters of sweetscented flowers. Specimens in 8 -inch pots readily sold at $\$ 10$ each. Our price, 20 cents, 50 cents and $\$ 1$.

CLEMATIS COCCINEA.-Small bell-shaped flowers of waxy texture; crimson outside, and tipped yel. low; blooms with wonderful profusion. 25 cents.

NEW HYBRIDS OF COCCINEA.-These plants were obtained by crossing C. Coccinea, with the large flowered sorts, and are sure to produce some very valuable novelties of new forms and colors. We hope to hear from those who flower them. The price of small seedlings is necessarily high. 50 cents. 3 for $\$ 1.00$. 


\section{New Rambler Roses.}

\section{THE CRIMSON RAITBLER.}

We were the first to advertise that grand rose in this country. It has been the sensational rose of the century, and is no doubt the grandest rose ever introduced. When established it makes numerous shoots 10 to 12 feet long and is smothered in spring with immense clusters of glowing crimson flowers. Small plants 15c., İarger 30c., 50c. \& \$1.

The Pink Rambler.-Same habit as Crimson Rambler. Color pink, clusters not so full. $15 \mathrm{c}$. to $50 \mathrm{c}$.

The White Rambler.-One of the best white climbing roses to date. Beautiful with above. 15c. to 50c.

The Yellow Rambler.-Same as Crimson Rambler. Flowers yellow. Very fine indeed. $15 \mathrm{c}$. to $50 \mathrm{c}$.

The Golden Rambler.-Our introduction. A continuous bloomer from early spring until December. Upon opening the buds are golden yellow, changing to white, so that white and yellow flowers cover the plant at one time with hun dreds of flowers. 15c. to $50 \mathrm{c}$.

One of each of these 5 Rambling Roses for $60 \mathrm{c}$, or with Clematis Rose $75 \mathrm{c}$.

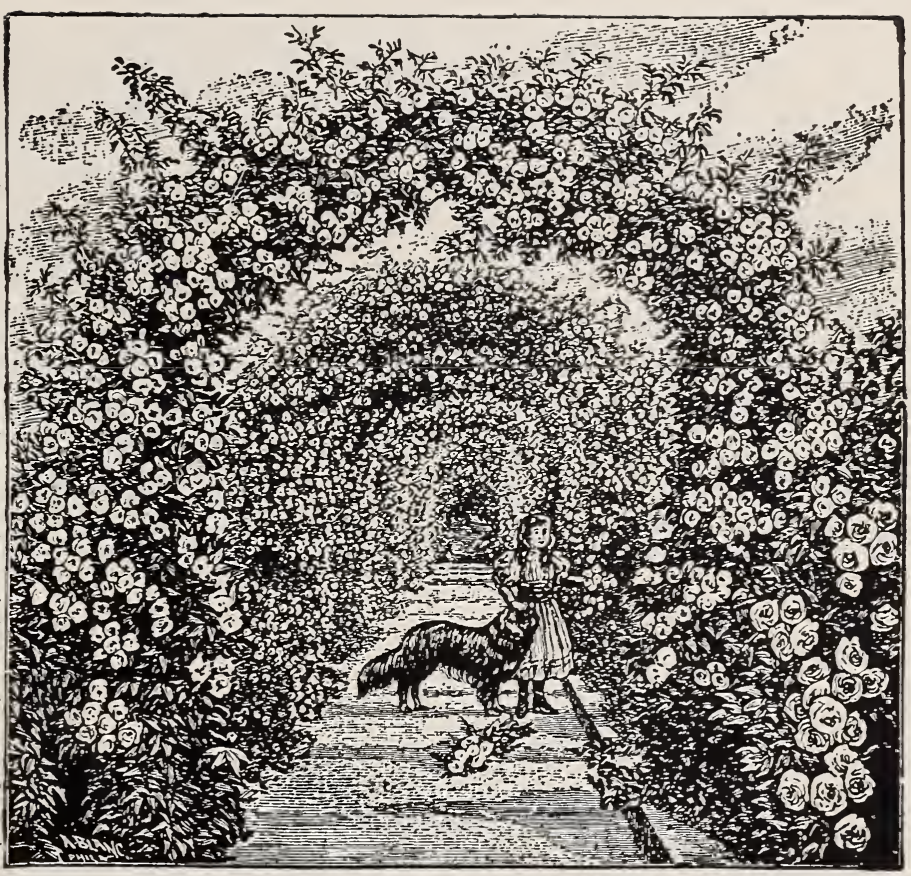

The New Clematis Rose, "Carmine Pillar."-Introduced by us in 1896. Its single flowers, 12 to 15 inches in circumference, of the brightest rosy carmine, cover the stems completely for 10 to 15 feet. $25 \mathrm{c}$.

$\downarrow$ Why not have an arched avenue of Ramblers of the varied colors. The effect would be grand indeed.

The New Rose Royal Cluster.-Altogether new. Blooms in inmense clusters of over one hundred flowers, are very double and exquisitely fragrant; hardy, vigorous climber; continuous bloomer. 15 to $30 \mathrm{c}$.

New Tea Rose “Palo Alto."-One of Mr. Burbank's new creations. The flowers are large, full and very sweet. The color is quite distinct, a lovely chamois rose with golden yellow clusters. Strong, healthy grower and almost constant bloomer throughout the entire season. Price 20c., extra large 50c.

Madam Von Siemen.-Grand garden rose. Long gaceful buds of a delicate flesh pink. $15 \mathrm{c}$.

Rose d'Evian.-A wonderful bloomer; long magenta buds, large and well filled when open. The color is a deep rich carmine rose, with deeper color on the outside Bushy growth. Large type 15c.

\section{$\star$ THE ORANGE ROSE, WITH PURPLE LEAVES.}

This is what the London "Garden" calls the grand new Rose "Souvenir de Catherine Guillot," which they so beautifully color-plated. It speaks of it as "One of the grandest and best garden roses ever introduced from France." The color is entirely distinct, being a coppery curmine, shruded with orange. The leaves, under favorable circumstances, being a rich purple. Flowers are large, full very sweet. $20 \mathrm{c}$. to $\$ 1$.

The Gireen Rose.-A curious flower which excites the wonder of all whe see it. Very beautiful. 15c. $\star$ \ New Rose, “Little Darling," or 1000 Blossoms, was sent out by Mr. J. E. Schmidt, of Erfurt, Germany, and is a perfect garden jewel, being literally covered during the entire summer with clusters of small blossoms of a delicate carmine rose. Should be seen to be appreciated. Very beautiful. 20c.

The Memorial Rose.-Creeps over ground like certain Ivies. Fine for cemeteries or embankments. $15 \mathrm{c}$. The Yellow Persian Rose.-Hardy as a rock. Fine clusters of yellow flowers. Large plants 20c.

$\downarrow$ Lord Penzance Hybrid "Sweet Briers." - The Sweet Briers, or Eglantine, possess the sweetest perfume nature has provided. The new varieties, which we were the first to offer, should be found in every garden. Four named sorts, deep rose, dark crimson, delicate blush and clear pink. $20 \mathrm{c}$. each.

Lucy Ashton.-Pretty white blooms with pink edges; not so large as some others; wonderfully free flowering; free grower, with rather erect shoots; foliage very sweet. $20 \mathrm{c}$.

Meg Merrilies.-Gorgeous crimson, very free flowering; seeds abundantly; wonderfully habit. 20c.

Rose Bradwardine.-Beautiful clear rose; perfect in shape, very profuse; strong, robust habit. 20c.

We furnish any rose offered by other firms and at the same prices. 


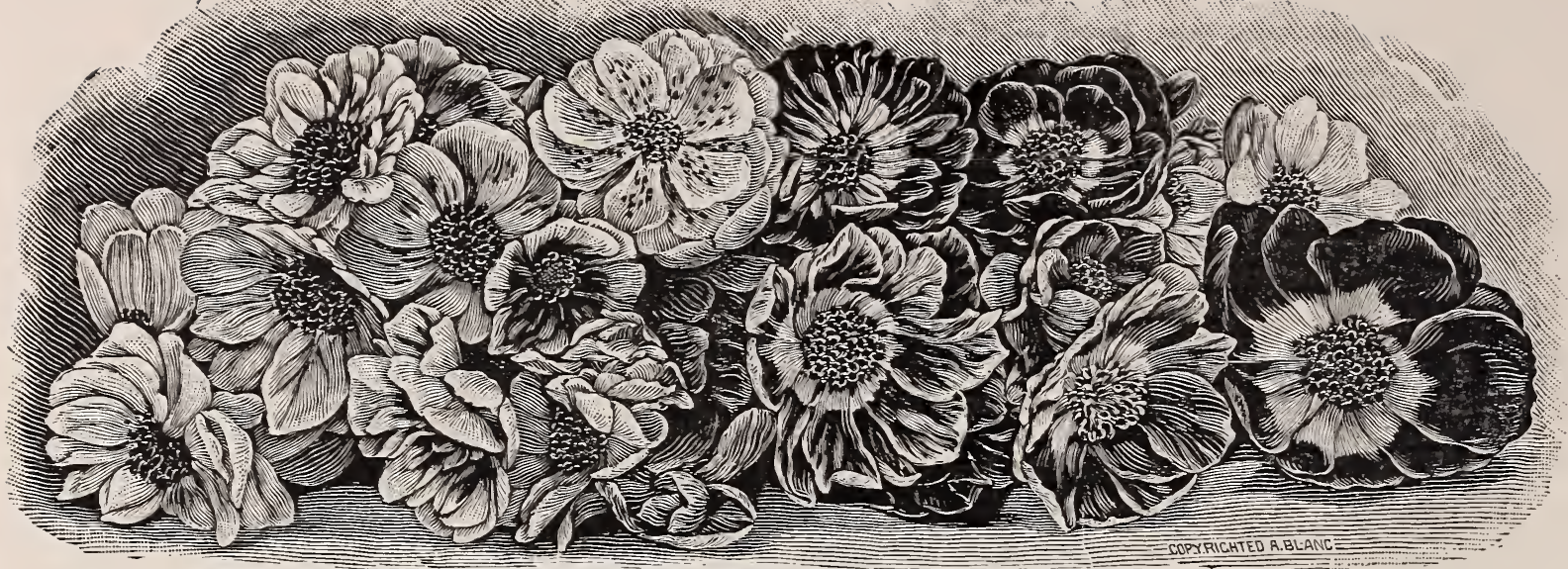

\section{SAINT BRIGID, OR POPPY ANEMONES.}

What could be more glorious than a bed of these new Irish Anemonies. Compare it to a kaleidoscope picture, glistening with and reflecting thousands of brilliant colors; or to some bright oriental carpet, whereon the artist has exercised his ingenuity to blend pleasing and effective tints. Indeed, the flowers of this new strain show all the colors of the rainbow and many more; for even black and white are found, as well as shades of pink, rose, crimson, fiery scarlet, carmine, maroon, lilac, lavender, blue, purple, even green. Some are curiously mottled, striped, edged, ringed and shaded with the various tints described, the effect produced being bewildering. They bloom frequently until well after frost. Being perfectly hardy, will bloom again the next season in greater profusion than ever. The flowers and the beautiful fern-like

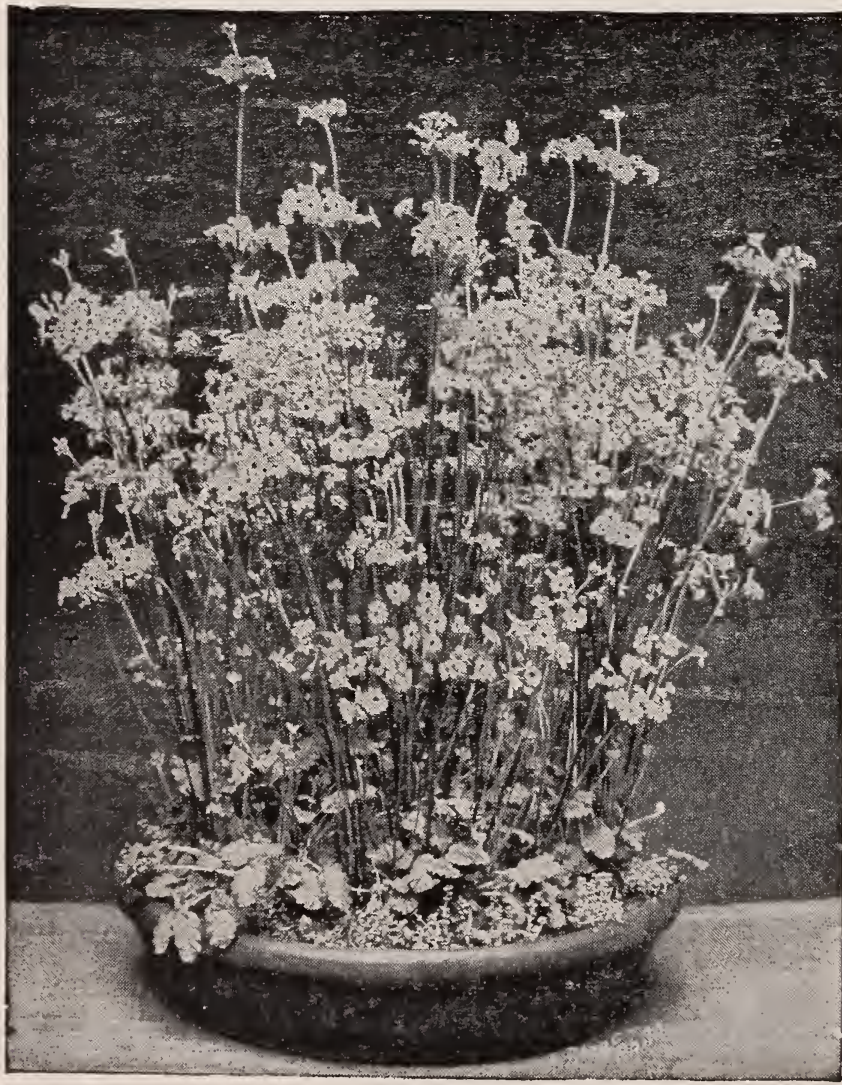
foliage remain fresh in water for a week or more. Fine roots 2 for $10 \mathrm{c}$, 6 for $25 \mathrm{c} ., 15$ for $50 \mathrm{c}$.

\section{PRIMULA FORBESI. "THE BABY PRIMROSE."}

Made popular by us last year, we unhesitatingly pronounce this one of the most valuable plants for flower lovers introduced for years, and one of the most profitably to grow for cutting. It blooms in thumb pots, when the leaves are scarcely 1 or 2 inches high, and continues to bloom for 10 months in succession, forming dense clumps of foliage crowded with dozens of long flower spikes, dainty and graceful, of a most pleasing rose color, with eye or centre of pale gold. They are carried in tiers, on erect but delicate stems, and positively remain fresh for two weeks after being cut. It is unequalled in keeping qualities by any other cut-flower that we know. We must add to all this, that the plant grows vigorously and witlont petting, ins shade or sunshine-even in a cool house-and that many will carry 200 flower spikes, and more, during the season. Price 15c., $\$ 1.25$ per 12 by mail, seed 10c.

\section{NEW PRIMULA "ISABELLINA."}

This has been christened the "Yellow Baby Primrose." It is of very dwarf growth and bears short spikes of yellowish flowers. 20c., seed 10c.

NEW EASTER PRITROSE "Obconica Grandiflora"

As a house plant one could scarcely find a better subject. It stands neglect and low temperature with impunity and keeps on blooming and blooming. This new strain bears very much larger flowers, which are almost pure white. Fine plants $15 \mathrm{c}$. Seed 10.

$A$ new fringed sort, quite rare, 20c.; seed $10 \mathrm{c}$. 


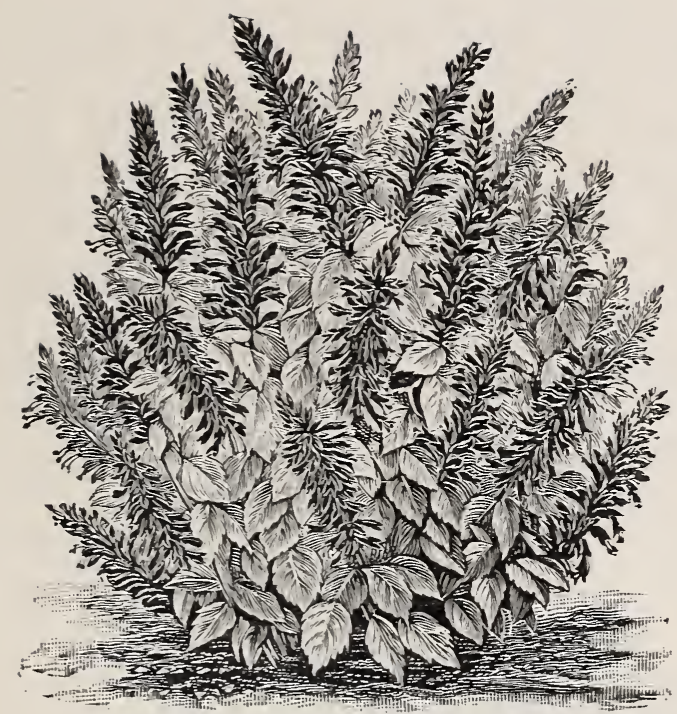

NEW SALVIA “ Spring Bloomer."

This is the greatest Scarlet Salvia in existence. It was introduced last year by $\mathbf{M r}$. Lemoine under the name of Souvenir de Jules Chretien, with the claim that it blooms a month to six weeks' earlier than other Salvia. It has done so for us. Its color, size, earliness and floriferousness places it ahead of any others. Very beautiful. 20c.

NEW SALVIA " Ruhm=von=Stuttgardt."

"Scarlet wonder" would be a good name for this. If Spring bloomer is the earlier-this is positively the freest bloomer of all, and no doubt the brightest of all in color. You should positirely have it. Extra fine sort. 20c.

\section{THE SILVER SAGE.}

Salvia Farinacea.-An old and almost forgotten Sage, but in our opinion one of the finest garden plants to be found. A large rase of the cut flowers was greatly admired at the Export Exposition last year. No one appeared to know it. - The flowers are borne in long upright racemes; the color is a combination of lavender and white. They last for two weeks when cut. A row of this in bloom is a grand sight indeed-hardy. 20c., the three Salvias 50c.

\section{THE NEW SNOW WHITE TREE LUPIN.}

Lupinus Arboreus. "Snow Queen" is one of the raluable introductions of $\mathrm{Mr}$. Peter Barr, of London, who praised it greatly during his recent trip around the world, as " $a$ grand novelty," forming dense bushes $4 \mathrm{ft}$. high, completely covered to the ground with elegant racemes of snow white flowers; valuable for the quantity of bloom it produces in early summer when white flowers are very scarce. 40c.

\section{THREE NEW GIANT FORGET $=$ ME $=$ NOT .}

Here is the "proof of the pudding." This photo. sent to us by $\mathrm{Mr}$. Heinemann, of Germany, shows what grand specimens it forms. Nothing like it has erer been seen. The flowers are carried on long and short stems, just as wanted, and for many weeks in succession. It is perfectly hardy. It has made a great hit among the florists and will be grown by the tens of thousands. Moreover we have it in three colors, white, pink and blue. 15c. each. 1 of each color for $30 \mathrm{c}$., 4 of each color $\$ 1$. Seed any color $10 \mathrm{c} .$, all colors mixed 10c. We particularly recommend these Forget-Me-Nots.

NEW WHITE FORGET=ME=NOT “Little Gem." - A beautiful pot plant completely covered with snow-white flowers of the greatest beauty. They are very dwarf and compact. 15c.
The Snow White Tree Lupin.

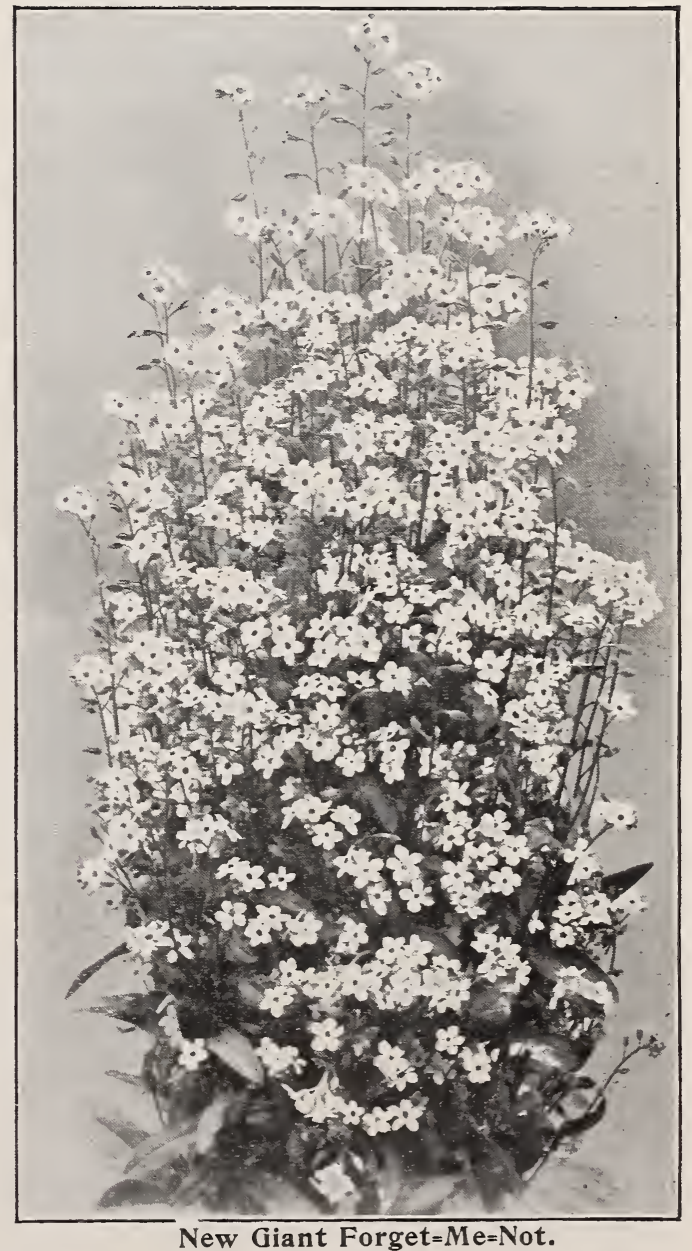




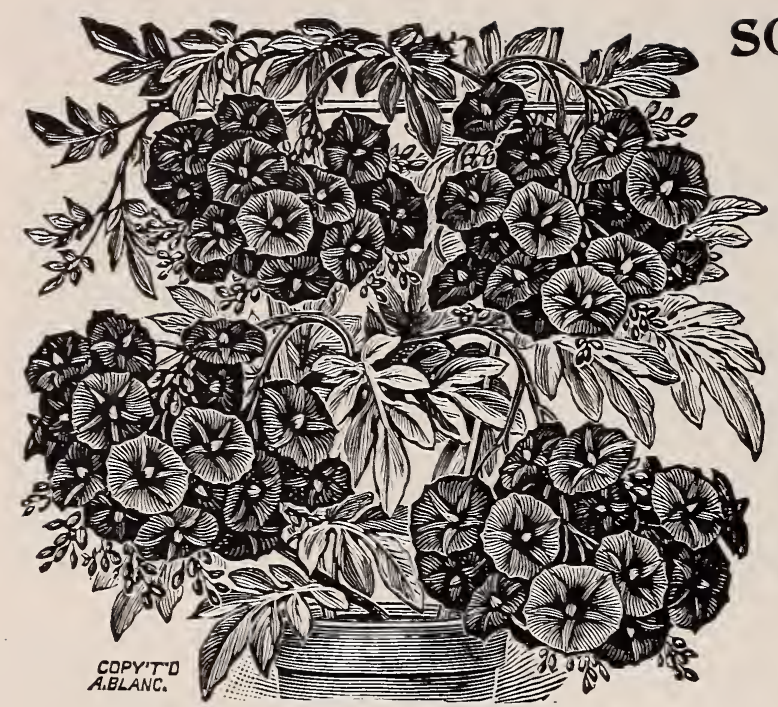

$\star$ SOLANUM WENDLANDI.

Introduced by us some years ago, this is still the most gorgeous flowering Solanum known. When only a few feet high, eren in the open ground, it will bear heads of flowers 2 feet and more in circumference, each with hundreds of lilac flowers $2 \frac{1}{2}$ inches across Not hardy North. $25 \mathrm{c}$.

\section{$\star$ GIANT TURKISH MOONFLOWER.}

An appropriate name given in Germany to the hardy Oriental Poppies, which have of late attracted so much attention. They are probably the largest flowers srown, measuring frequently a foot across. The colors are most intense red, and can be seen, so to say, for miles. Everyone who has a garden must certainly grow them. They are grand beyond comparison.

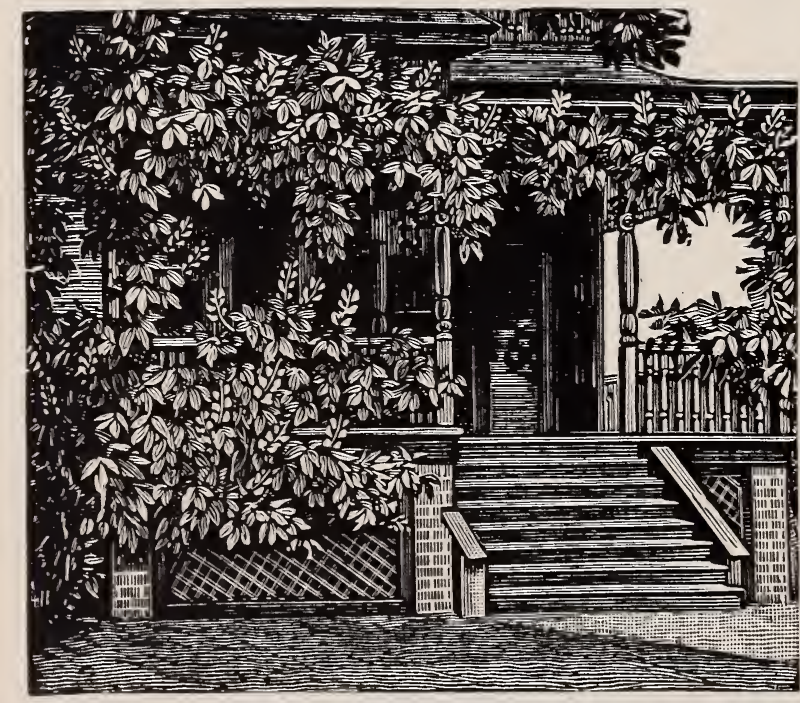

The Japanese Kudzu Vine.

\section{$\star$ THE CRIMSON SPIRAEA.}

Spiræa Anthony Waterer is of Japanese origin, introduced by us some years ago. It is now acknowledged as the ideal florists' plant. When scarcely three inches high it begans to bloom, and thereafter is seldom out of flower. In the garden it will make a plant 3 feet high and wide, and will be covered with heads 1 foot across, of brilliant crimson flowers. It was a warded several first-class certificates. Mr. Golding, of the Royal Gardens, Kew, says of it: "It is one of those exceptional novelties that occurs only at rare intervals. $15 \mathrm{c}$.

CHINESE LANTERN PLANT, Physalis Francheti.

Another of our introduction. It was abused by some, but now universally admitted to be a most valuable garden and house plant. The grand brilliant red, balloon-like fruits are grand for indoor decoration. $15 \mathrm{c}$.

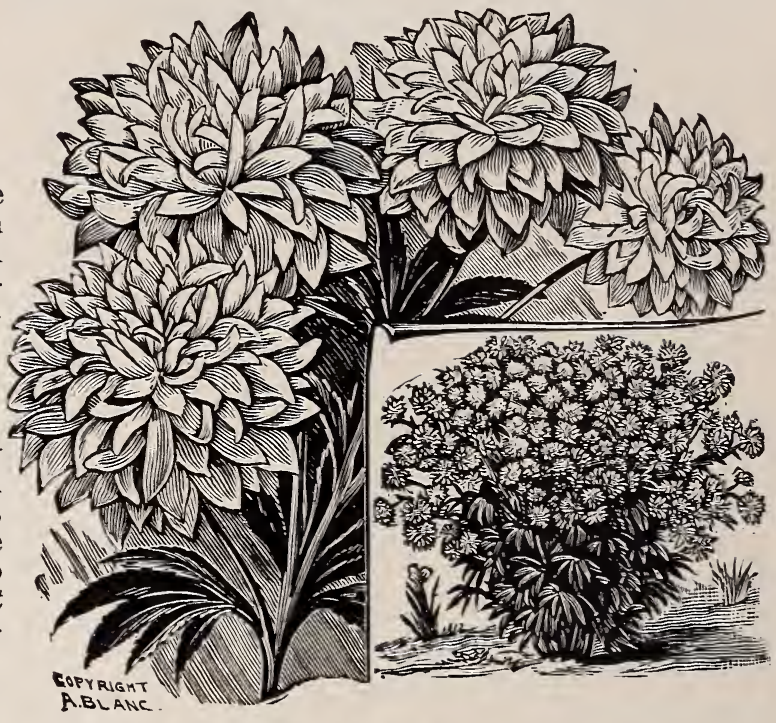

DOUBLE RUDBECKIA, Golden Glow.

Gardening, the most valuable of all horticultural journals, speaks of this new plant as follows: "We hail it with delight, as being one of the most distinct and beautiful hardy perennials introduced for years." It will give you armfuls of large, very double golden yellow flowers, elegantly set off with their own foliage. 20c.

\section{THE JAPANESE KUDZU VINE.}

A rapid-growing vine, recommended by the most prominent horticulturists. Dense green foliage, which quickly covers porches, verandas, rockeries, tall trees, etc. Flowers purple, in large clusters. From the root a starch is made, and valuable cloth from the stems, while the abundant foliage is eaten by cattle. Hardy as a rock. Seed 10c., plants 25 c.

\section{CROTALARIA RETUSA.}

As the Dwarf Yellow Pea, this has been extensirely advertised. It grows about 2 feet high, and every shoot is terminated by long racemes of bright yellow, pea-shaped flowers. When grown in quantity it is said to be like a shower of gold. 15c., seed $5 \mathrm{c}$. 


\section{NEW HIBISCUS "ARCHERI"}

When the London "Garden " deems a "new" plant worthy as one of its subjects for a colored plate it may always be considered as a good plant that can be recommended. We have had it for some years, and can positively say that it has never been out of bloom.

Its immense glossy carmine red flowers, carried on almost erect stems, are entirely distinct from any other Hibiscus in that they are deeply cut, fringed and scalloped. They also last much longer in beauty than any other. This plant so impressed Mr. Wm. R. Smith, of the White House gardens, that he ordered a number of them, and we propagated it upon his advice. Being a strong grower, it can be kept down to bushy form, and therefore easily landled, either as a pot plant or for bedding out on the lawn. This will be a favorite plant with you. Price $20 \mathrm{cts}$.

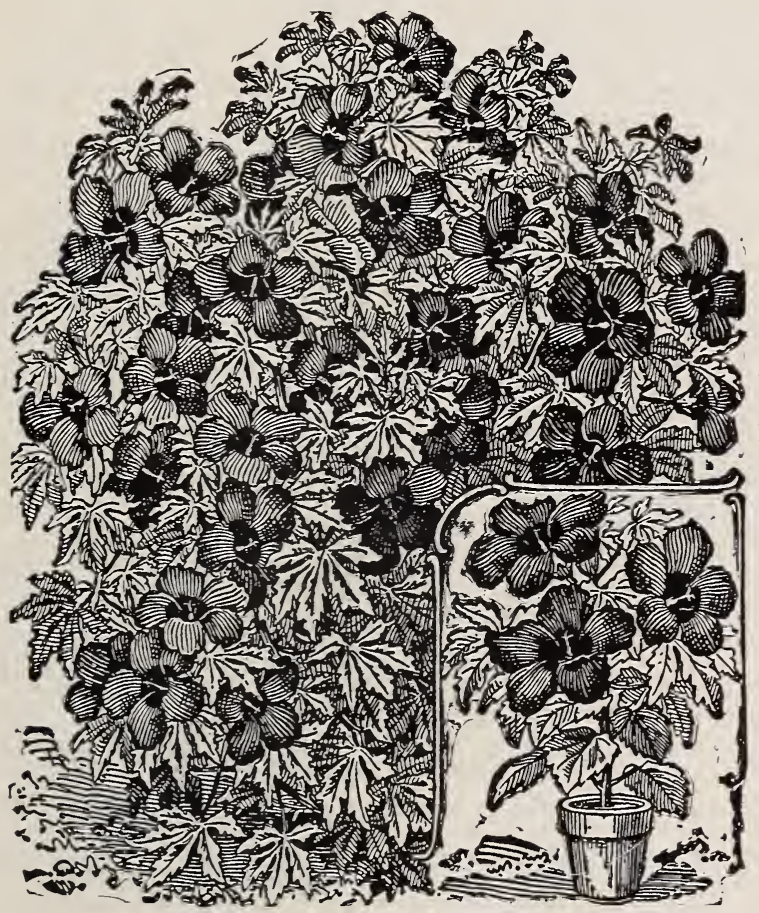

Southern Beauty Hibiscus.

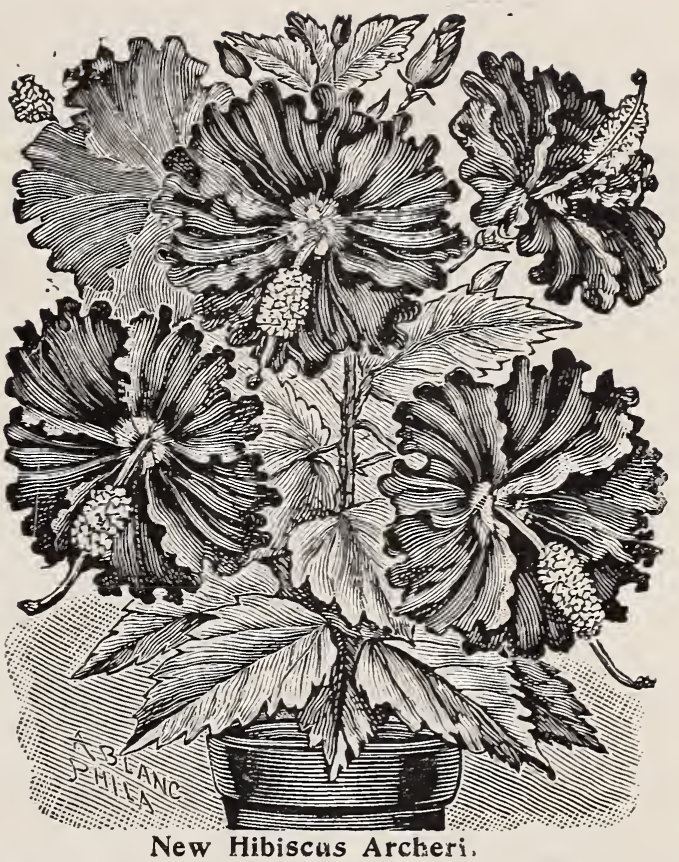

HIBISCUS “SOUTHERN BEAUTY”

Every limb and twig is clothed with deeply 5-cleft leaves, toothed and crimson-margined. All summer and fall (until checked by frosts) it covers itself with handsome and very striking flowers, deep crimson, shading darker in the throat. As a pot plant it blooms while very small, and we have had them in thumb pots c a r r y ing flowers larger than the plants themselves. May be wintered in pit or cellar. Nice plants, $15 \mathrm{c}$.

\section{NEW DOUBLE HIBISCUS “PEACHBLOW,"}

The Double Flowering Hibiscus are not free bloomers as a rule, but this one really is. So much that plants in three-inch pots frequently bear 5 to 8 opened flowers and show buds from every leaf. If kept growing and repotted when needed it would bloom perpetually. The flowers are accurately shown in cut, although occasionally a semi-double flower occurs. In color this is entirely new, being a salmon rose, shading to deep carmine red towards the base of the petals. Like the Archeri, this is also a fine bedder, both standing the sun remarkably well, A year ago one plant could not have been bought for 100 dollars. Thanks to its rapid growth, the price now is 30 cts., or, with H. Archeri, 40 cts.

NEW DOUBLE WHITE HIBISCUS “JEANNE D' ARC."

A grand sort, with immense pure, white double flowers, perfectly hardy; blooms at once. $25 \mathrm{cts}$.

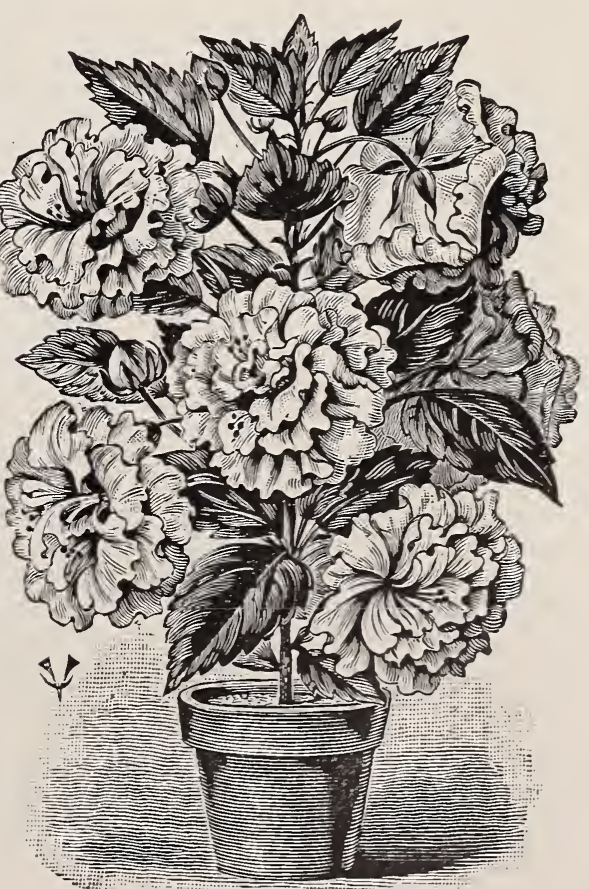

New Hibiscus "Peachblow." 


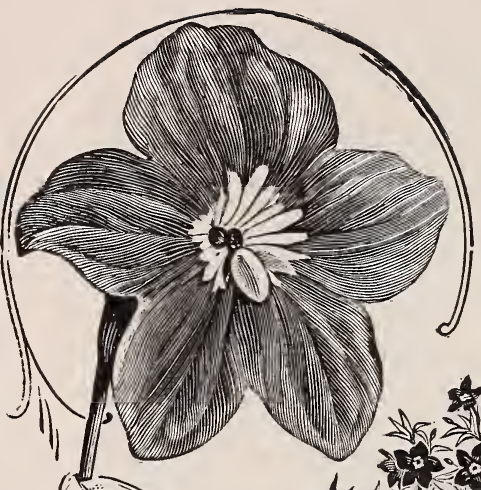

$\star$ RUELLIA MAKOYANA.

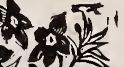

(Carmine Blossoms.)

A new Brazilian plant of easiest growth for the house as well as the garden, forming in a short time specimens measuring two to three feet across, with over three hundred flowers open at one time. Leaves velvety, dark olive green, with prominent silvery white midrib and veins ; underpart purplish wine color and very ornamental. Flowers large, brilliant carmine, produced even on plants in 2-inch pots, and almost during the entire a fine Gaster plant. We positively recommended it as one of our
finest introductions of recent years. It was exhibited at the great
floral display of Ghent in grand specimens, measuring nine feet
around. Will grow far easier than a geranium, but a fine Easter plant. We positively recommended it as one of our
finest introductions of recent years. It was exhibited at the great
floral display of Ghent in grand specimens, measuring nine feet
around. Will grow far easier than a geranium, but a fine Easter plant. We positively recommended it as one of our
finest introductions of recent years. It was exhibited at the great
floral display of Ghent in grand specimens, measuring nine feet
around. Will grow far easier than a geranium, but a fine Easter plant. We positively recommended it as one of our
finest introductions of recent years. It was exhibited at the great
floral display of Ghent in grand specimens, measuring nine feet
around. Will grow far easier than a geranium, but another of the star plants introduced by us in this coun-

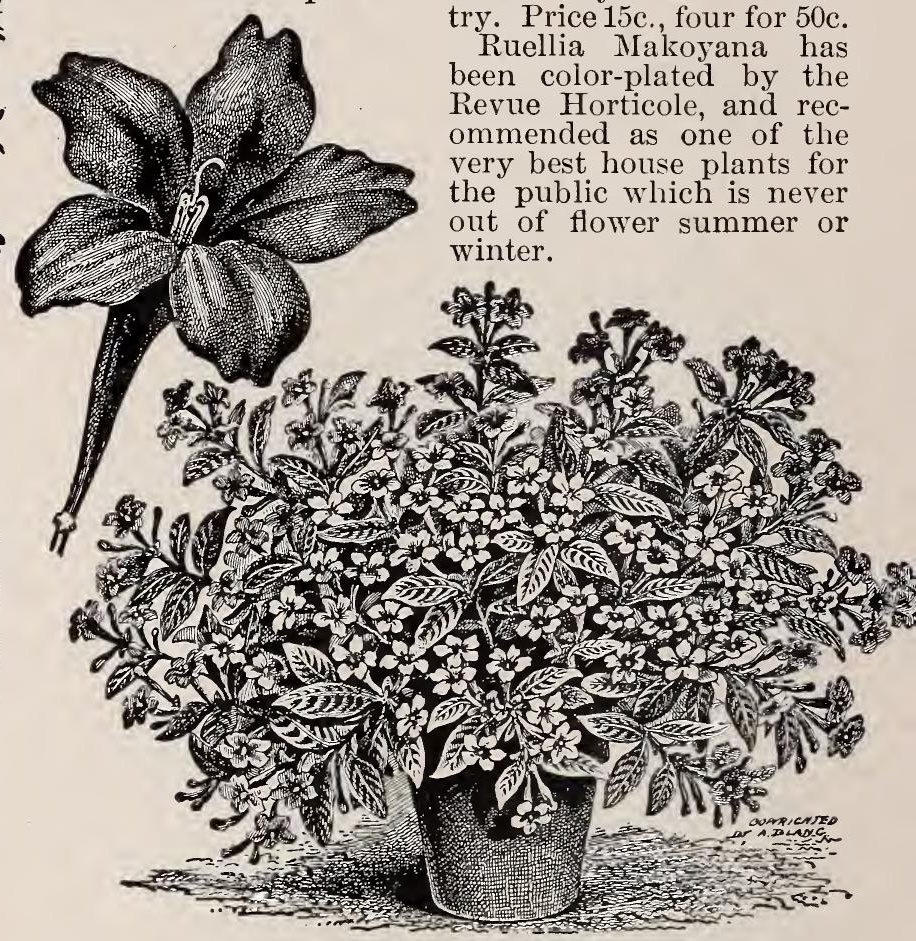

Ruellia Makoyana. (Carmine Blossoms.)

THE ORANGE VIOLET. (Browallia Jamesoni.)

Inasmuch as Browallia Speciosa Major is now popularly known as the Giant Violet, we think the Orange Violet a good name for our plant. It is a well-known but neglected beauty, which would create even a greater sensation than its violet-colored sister, even with less care. Well grown specimens, a foot or two across, are really grand, the innumerable bright orange flowers giving it the appearance of a golden bush. If propagated from slip cuttings it blooms as soon as rooted and almost perpetually afterwards. Price $15 \mathrm{c}$.

EUPHORBIA JACQUINIFLORA. (Scarlet Jewels.)

No other flower can possibly compare with this in brilliancy and gracefulness. Its long arching sprays, covered for a length of two feet with orange scarlet flowers and dark green leaves, are always in demand by the elite of the craft, who pay high prices for it. We sold 1,000 plants to one of our most prominent growers, "who wished he had a houseful of it." Small plants, price 20 c.

The Orange Violet. 


\section{Three New and Rare Plants from Distant Shores.}

STRELITZIA REGINA.

\section{The True Bird=of=Paradise Flower.}

This is undoubtedly one of the most gorgeous flowering plants in existence, and although discovered 120 years ago, is even rarely found in Botanical Gardens. The leaves are very leathery, supported on stalks 2 to 3 feet long, and last for years. The flowers are freely borne in dense scapes a foot across, the colors being orange $=$ yellow and purple, a most unusual and rich combination. They remain perfect for months at a time, and are great objects of admiration. Any one can grow this plant under most adverse circumstances. In the South and California it will be found perfectly hardy.

Price of strong plants, $\$ 1$ up to $\$ 5$. Seeds, 5 for $25 \mathrm{cts}$.

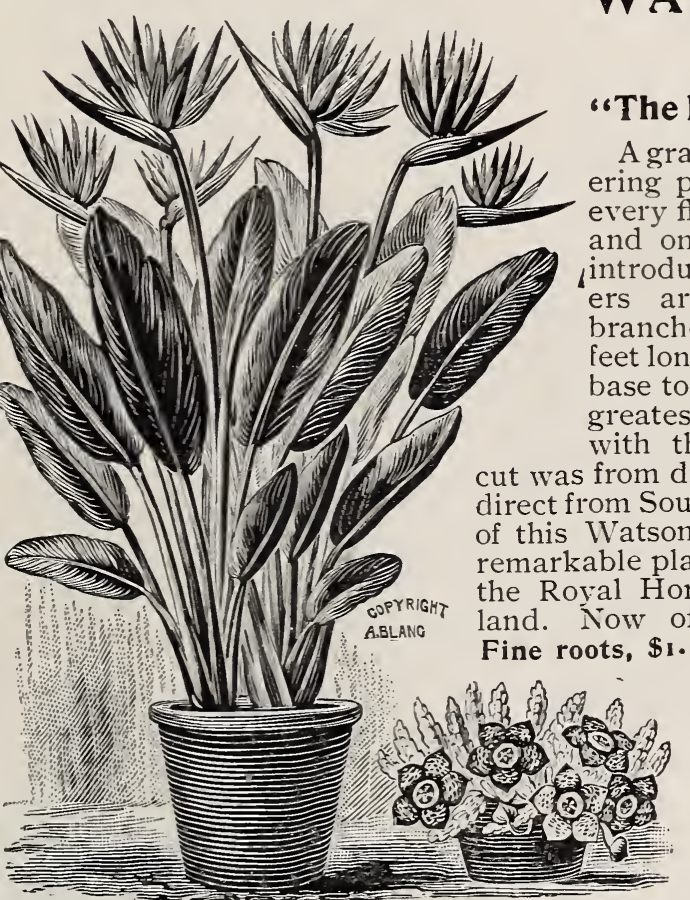

Strelitzia Regina-The True Bird=of=Paradise Flower.

\section{EURYCLES AMBOINENSIS. The Brisbane Lily.}

It is not always our fortune to obtain this extremely rare species, a native of Amboyna, which we have grown even out of doors with the greatest ease. The foliage is broad and ornamental. It is free-flowering, and produces large heads of elegant white flowers. Price reduced from $\$ 1.50$ to $50 \mathrm{cts}$. The above 3 New Plants for \$2.20.

THE BLUE TRIGIDIA. Tigridias are familiar to most flower lovers, but the blue-flowering sort is entirely new. There is just enough red and yellow combined with it to make the effect marvellous. Just a few bulbs at 50 cts. each; more next year. I5 seeds, I5 cents. Blooms first year.

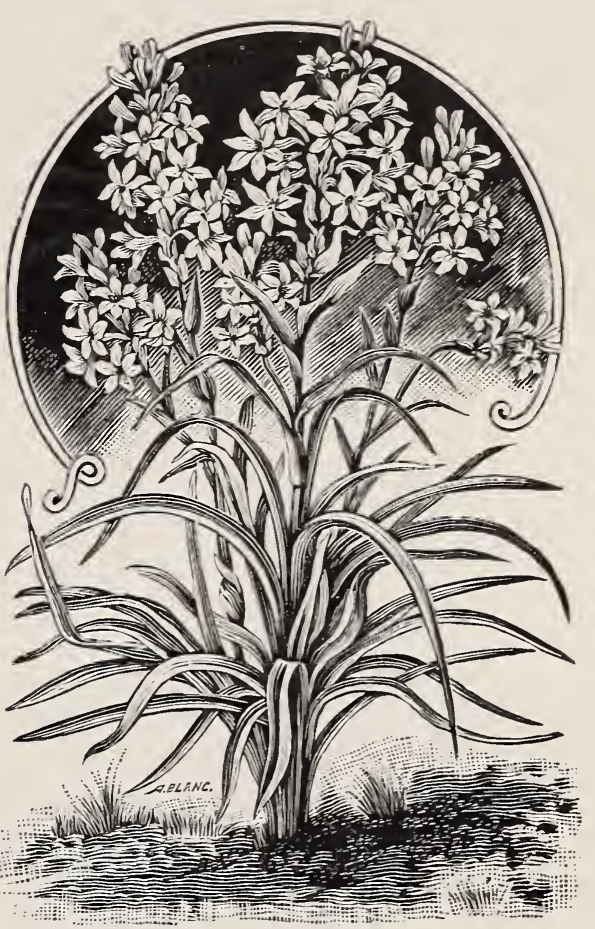

Watsonia Ardernei-

"The Pride of Algoa Bay."
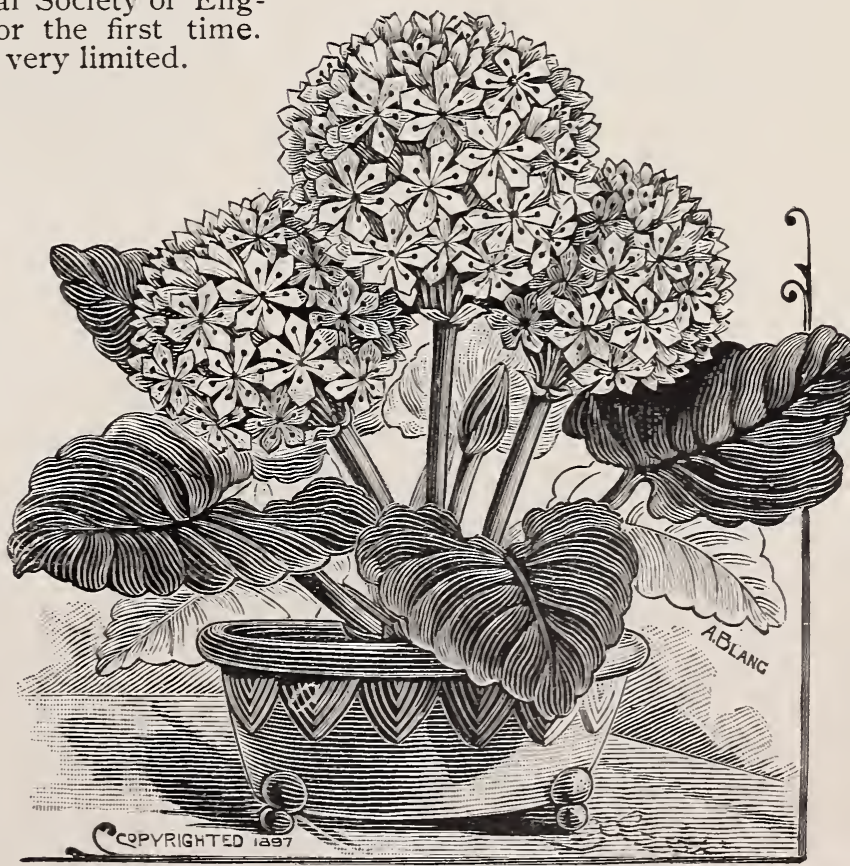

Eurycles Amboinensis-The Brisbane Lily. 


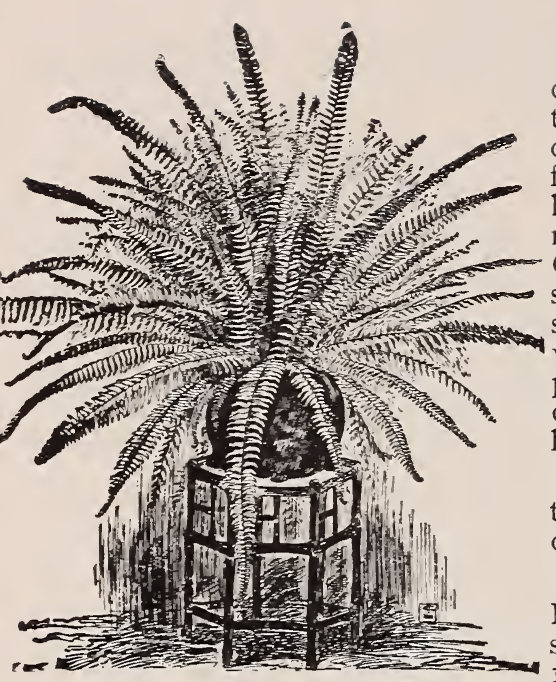

THE BOSTON FERN.

Nephrolepis Exaltata Bos= toniensis,-Next to Asparagus Sprengeri, this is one of the most popular parlor plants to-day. It differs frcm other Ferns in having much longer fronds, which frequently attain a length of 4 feet. These fronds arch and droop orer gracefully, hence it is sometimes called the Fountain Fern. The plant stands dry heat remarkably well, and makes fine single speci mens for tables or halls; grows beautifully in Jadoo. I5 cents up to $\$ 6$ for immense specimens.

\section{ASPARAGUS SPRENGERI.}

When making up your order for Palms, etc., do not forget Asparagus Sprenge - the Abyssinian Parlor Fern. We grov 60,000 plants of it. Price, I5 cents to \$1O. Send for pictures of large specimens.

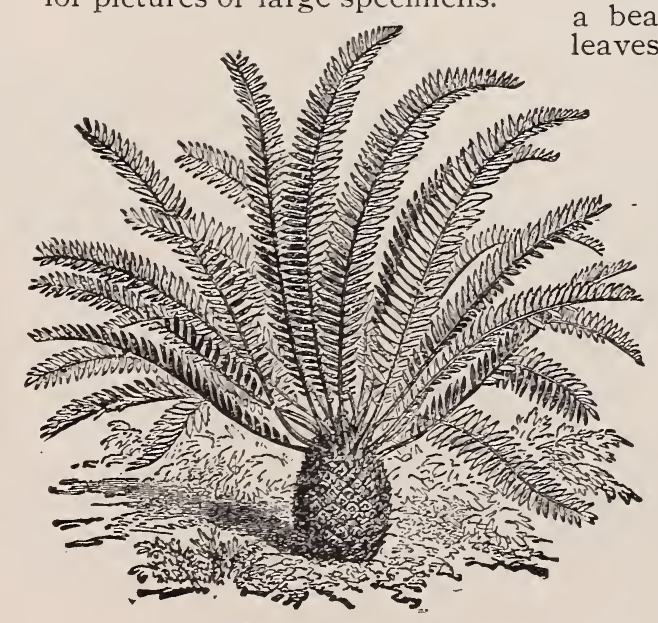

Zamia Integrifolia.
AUSTRALIAN TREE FERNS.

Alsophila Australis.-In all firstclass greenhouses and at floral exhibitions, these Ferns are always in evidence. Their elegant airy fronds of fresh pale green color are like delicate lace work, and yet when young they make a most excellent house plant. Given an abundance of water in the saucers, they grow amazingly in a short space of time, soon forming very valuable specimens. Fine young plants for room culture, 25 cents, 50 cents and \$I. Large specimens, with heavy trunks, $\$ 5$ to $\$ 10$.

Dicksonia antarctica.-Similar to above, but with heavier trunk and darker foliage. Same prices.

JADOO is the material to grow Palms and Ferns to perfection. We send 5 lbs. by express for 30 cents, IO $1 \mathrm{bs}$. for 50 cents, $25 \mathrm{lbs}$. for \$I.ro. It is light, and will pay you to use it.

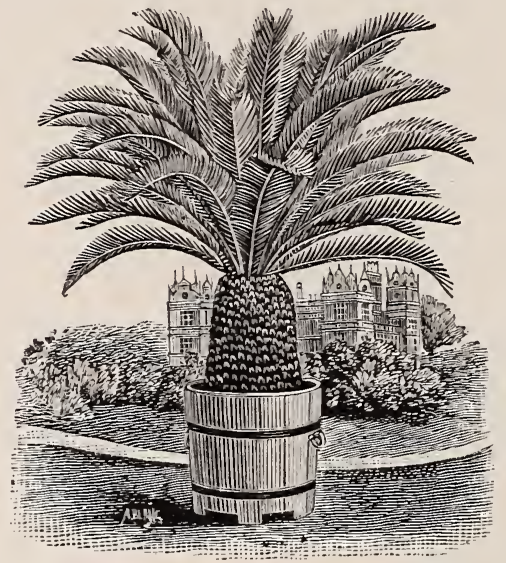

The Sago Palm.

\section{WASHINGTONIA FILIFERA.}

The Weeping Palm is certainly a beauty. Its large, silvery green leaves are most handsome and graceful, covered as they are with long silky threads. It is a fine house Palm, and the very best for growing in full sun out of doors. Easily raised from seed. Pkt. Io cents, plants 2.5 cents.

\section{ZAMIA \\ INTEGRIFOLIA.}

Quite similar to the Sago Palm, but much sinaller in growth, increasing in beauty each year. An excellent room or table plant. Dry roots (easily started) 35 cents, growing plants 50 cents to $\$ 2$.

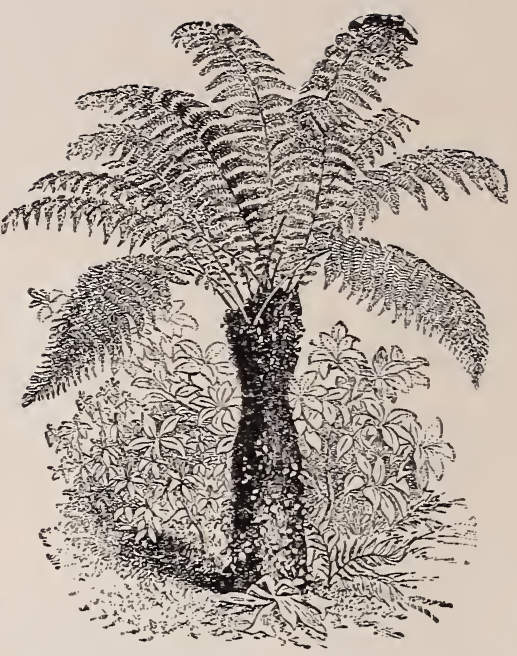

Australian Tree Fern.

THE SAGO PALM.

Cycas revoluta is the noblest Palm in existence. Every one who has seen large specimens of this Japanese wonder must admit that it is without a rival. Its deep green, shiny and everlasting foliage, curving so gracefully, is extensively used for decorating; large leaves selling a $\$$ \$5 per pair, while large plants frequently bring from \$200 to $\$ 500$ per pair; specimens hundreds of years old are known. Extra fine for lawn, porches, entries, etc. Price, small plants, 50 cents ; larger, \$I up to \$2O.

\section{BOOK ON CACTUS.} roo pages, full of illustrations. Price, Io cents. WVe have 700 sorts of Cactuses. Catalogue free.

\section{THE GOLDEN MORN=}

ING GLORY, page $3 \mathrm{I}$, is frequently covered with I,000 flowers.

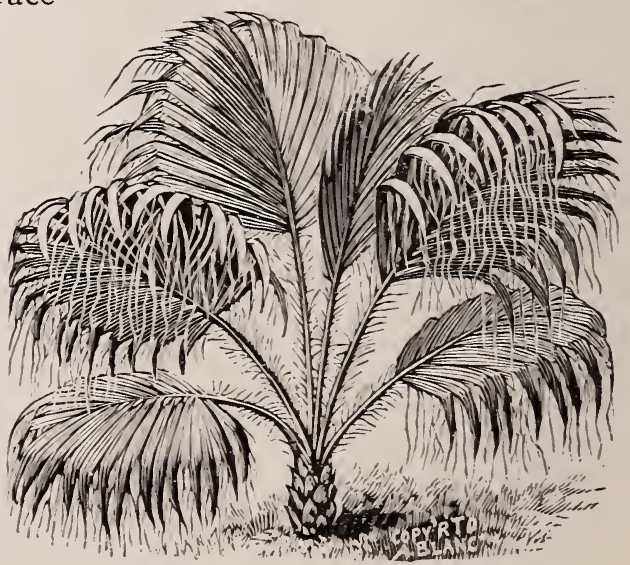

Washingtonia Filifera Palm. 


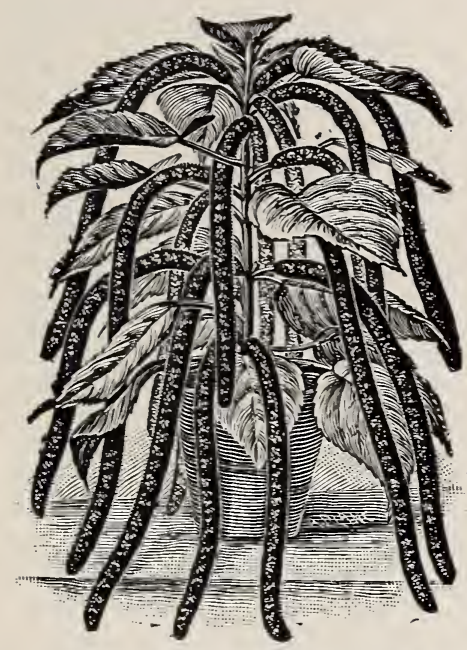

NEW ACALYPHA SANDERI.

As the "Philippine Medusa" this created a great sensation last year, when first introduced. 'The long drooping scarlet tail-like flower spikes last in beauty for many months. If cut back the plant grows dwarf and bushy, but it will also grow to a height of many feet when trailed on porch or large lattice. 20c.

\section{NEW ANEMONE LaFIANCEE. "The Bride."}

Introduced recently by Mr. Krelage of Harlem, Holland. This is recognized as the only double, pure white Anemone and a very valuable acquisition. It is sure to be wanted as a fine cut flower and is a wonderfully fine bloomer. We have only a few plants and these the only ones in this country. 30c.

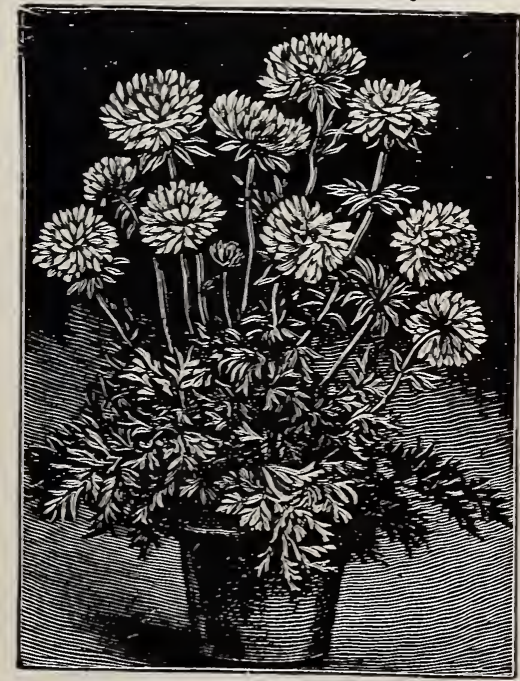

New Anemone LaFiancee.

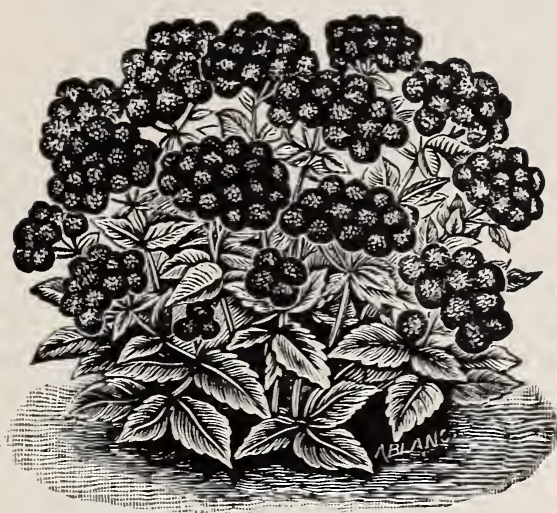

AGERATUM STELLA GUERNEY.

Entirely new this year and by far the dwarfest and most profuse bloomer of ll the ageratums. $15 \mathrm{c}$.

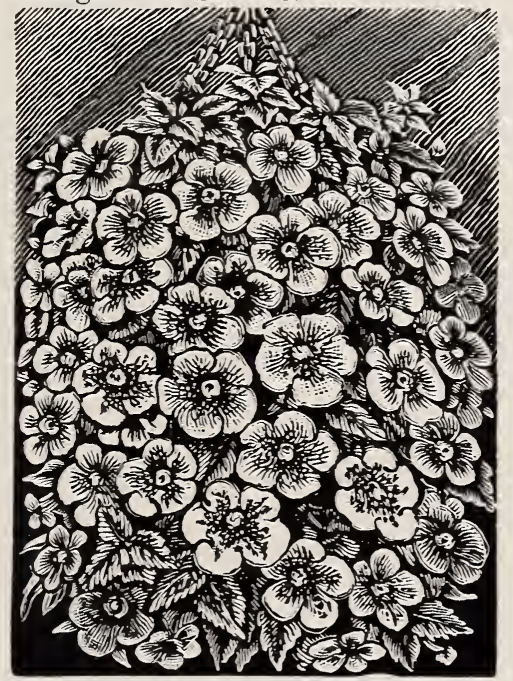

NEW ACHIMENES.

All of a sudden these have become exceedingly popular and no wonder. The grand photos published in several journals prove plainly what wonderful specimens they form in a few months from a few small plants started in pots or baskets. The shades of colors are inn umerable in their combinations and the markings and spotting bewildering. Really they are so grand and so easy to grow that we recommend them. Late in fall when done blooming you will find lots of little bulblets. Keep these in sand or soil over winter to start again in early spring. Young plants 15c., 4 different colors 50c., seed 10c.

\section{ANEMONE LADY ARDILAUN.}

Grand garden plant. Large pure white flowers $15 \mathrm{c}$.

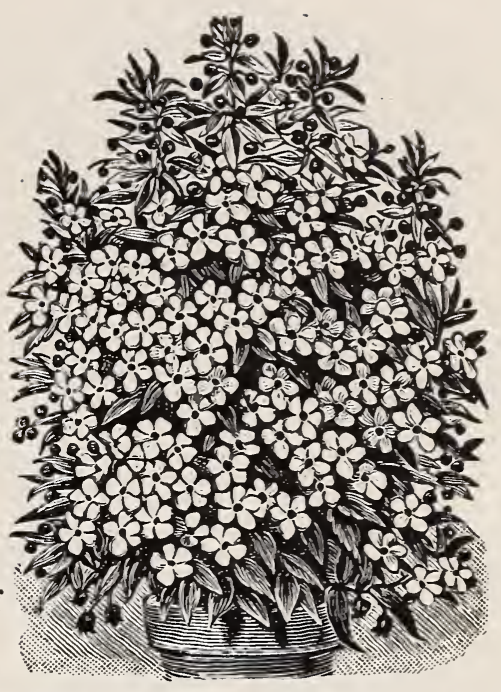

NEW ANGELONIA GRANDIFLORA.

A fine novelty now offered for the first time. This beautiful pot plant is especially adapted for room or garden decoration and completely covers the dark foliage with violetlike flowers, which have a unique strong aromatic odor. Two colors, white and blue, 25c., the 2 for $40 \mathrm{c}$.

\section{NEW ANTIRRHINUMS.}

The new sorts are so far superior to those raised from seed as to be almost new species. Coral Pink bears enormous flowers of a lovely unique color. Yellow Queen is indeed the queen of the golden colors. While IThite Queen has never been excelled as a white. If you want flowers all the time these are the ones. $15 \mathrm{c}$., the 3 for $40 \mathrm{c}$. Seed $10 \mathrm{c}$.

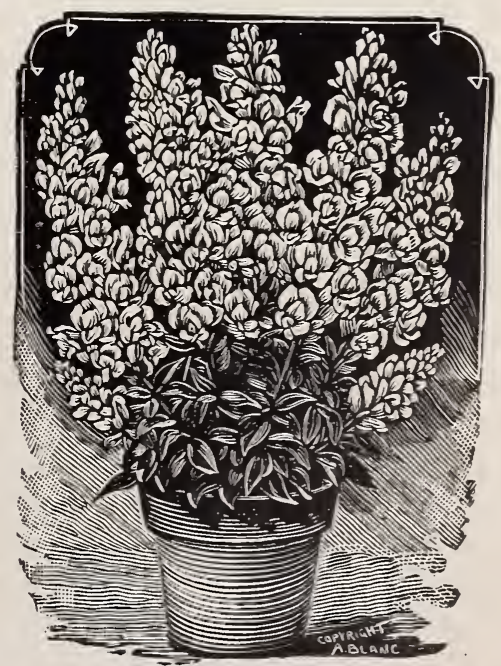

New Antirrhinums. 


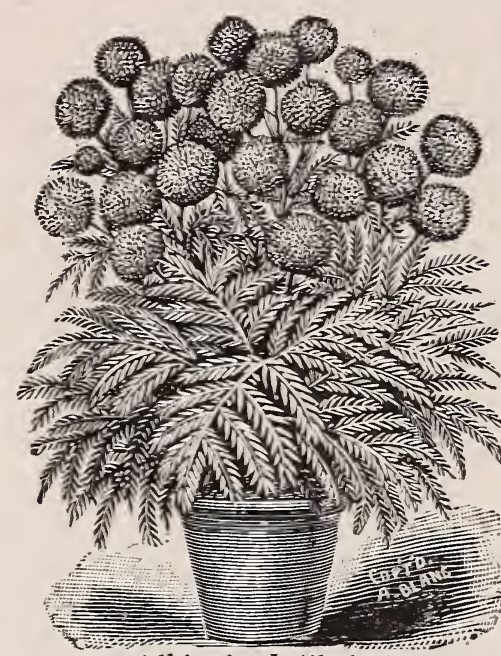

Albizzia Julibrissin.

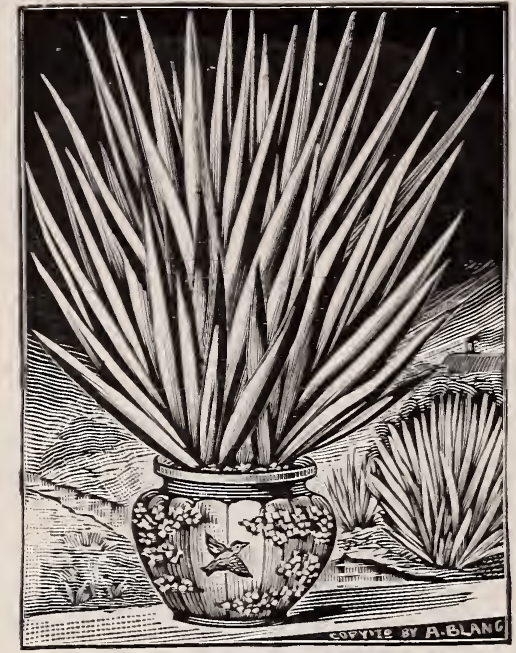

Acorus Japonica Variegata.

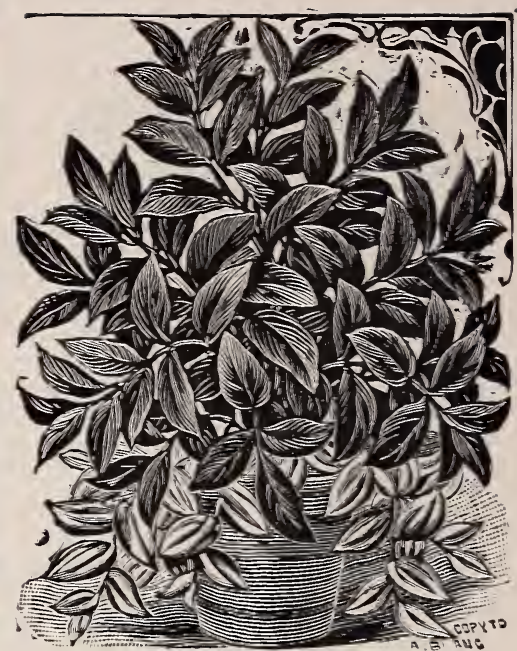

Aerva Sanguinea-Blood Leaf,

ACORUS VARIEGATA.-A beautiful Japanese rariegated-leared plant of ornamental appearance. Excellent for borders of streams, for aquariams or indoor pot culture. Leaves almost pure white or streaked with green. It prefers plenty of water, and is perfectly hardy anywhere. 25 cents.

ALBIZZIA JULIBRISSIN-Rose Acacia (New).-Elegant rose-colored, silky tassels, resembling the delicious Metrosideros, borne above delicately cut foliage, as graceful as a fern. Always beautiful, whether in hloom or not. Fine ornament as a table plant, and also quite hardy, though a native of Persia. Plant, 20 cents: seed, 8 cents.

ASPARAGUS SPRENGERI (our introduction).-Perhaps the best new plant introduced within ten years! Highly praised everywhere; handsomest seen drooping from a pot or basket. Sprays 4 to 5 feet long, of fresh green feathery foliage, useful for bouquets, wreaths or sprays: remaining perfect for weeks after cutting. Grows freely the whole year around. Extremely valuable for all purposes. Flowers white, fragrant, followed by red berries. 15 cents to $\$ 2$; seed, 10 cents.

AERVA SANGUINEA-Blood Leaf.-From South America. It is an elegant indoor plant, with dark deep red leaves, forming a charming contrast with other green-leaved plants. Good novelty. Grow this and Basella together and produce a fine effect. 15 cents.

AGAPANTHUS UTBELLATUS-The
Blue African Lily. - Imagine a clump of bright evergreen foliage, spreacing 3 to 4 feet if permitted, and surmounted by 30 to 40 spikes of large, bright blue, lily-like flowers! Easiest culture. 15 cts; seed, 8 cts.

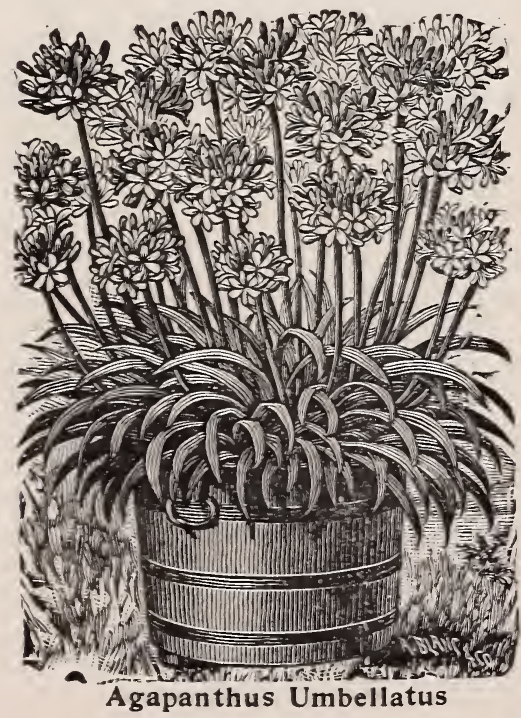

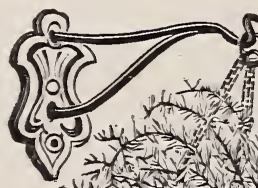
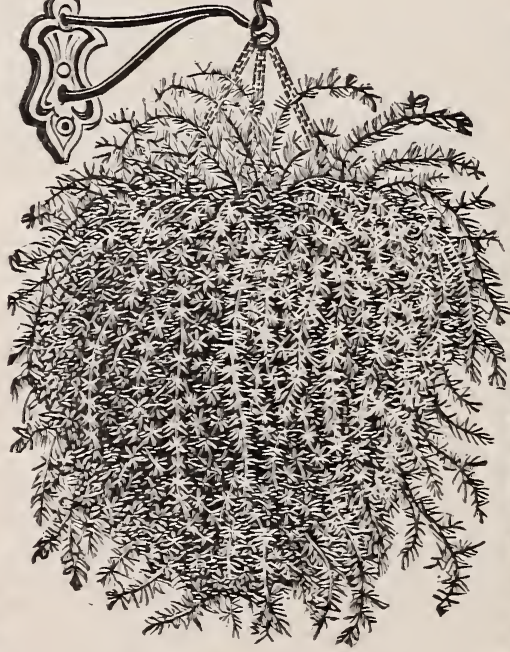

Asparagus Sprengeri.

ANTIGONON - Mountain Rose.Numerous clusters of deep pink blossonis so completely cover the vine as to almost hide the foliage. Grand and effective when grown in a sunny spot. Hardy, with slight covering. $15 \mathrm{cts}$.; seed 5 cts.
THE WHITE AFRICAN LILY.Same as Agapanthus Umbellatus; flowers pure white; rare. A plant that will please you. 35 cents.

THE DOUBLE BLUE AFRICAN LILY.- Just like above, but with large heads of double flowers. $25 \mathrm{c}$.

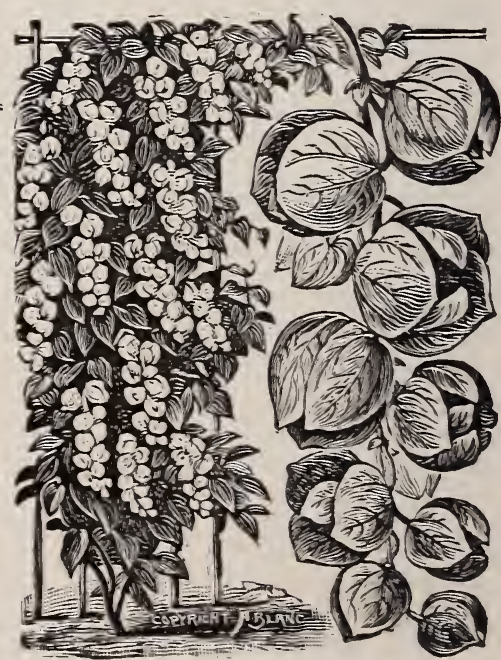

Antigonon-Mountain Rose. 
BEGONIA, “DUKE ZEPPELIN”

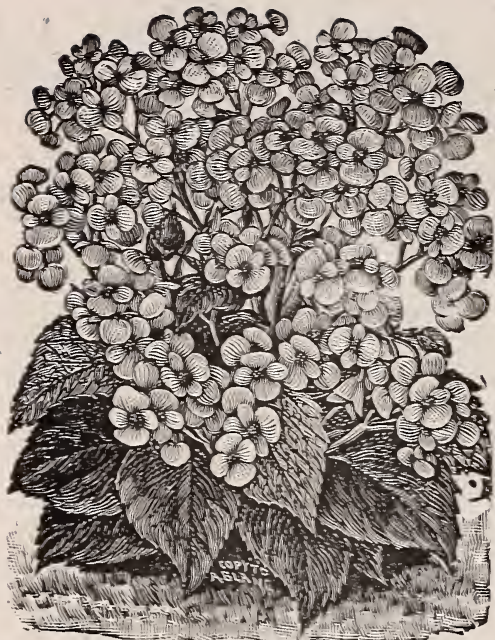

HARDY CHINESE BEGONIA EVANSIANA. "Sweet Scented."

Few florists will believe that this Begonia is perfectly hardy, ret it survived a temperature of 20 degrees below zero in Pennsylvania and has occupied the same spot for rears. It forms small bulblets in the axils of the leaves, which remain in the soil all the winter, and growing vigorously during the entire summer, forming a bush or bed two feet high, with lecres of rich olive green, the under part being light and beautifully netted with bright red veins. The leares are often 6 inches long and 6 broad. It is a most profuse bloomer, the stems standing well above foliage. The flowers have a fragrance quite unknow in Begonias. 15c., 4 for $50 \mathrm{c}$.

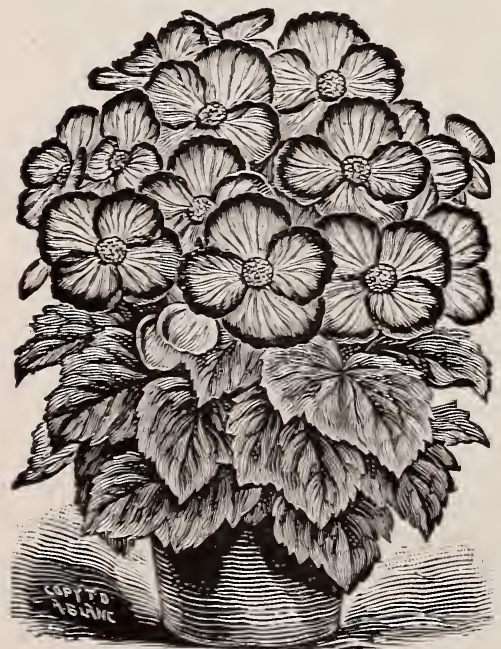

Mlammoth-flowering Begonias.

This is undoubtedly the most gorgeous summer flowering Begonia ever produced, and elicits exclamations of delight from every one who has had plants, which bloomed for us out of doors from May until October. The waxy, glossy, glowing scarlet flowers, as double as Camellias, completely hide the foliage from view, so that at a distance only a solid mass of blooms can be seen. It stands the sun better than any Begonia we know of, and cannot fail to become a standard bedding plant, and blooms also well in winter. Its popularity is assured by hundreds. Our low price brings it within reach of all. Price $25 \mathrm{c}$., 3 for $60 \mathrm{c}$.

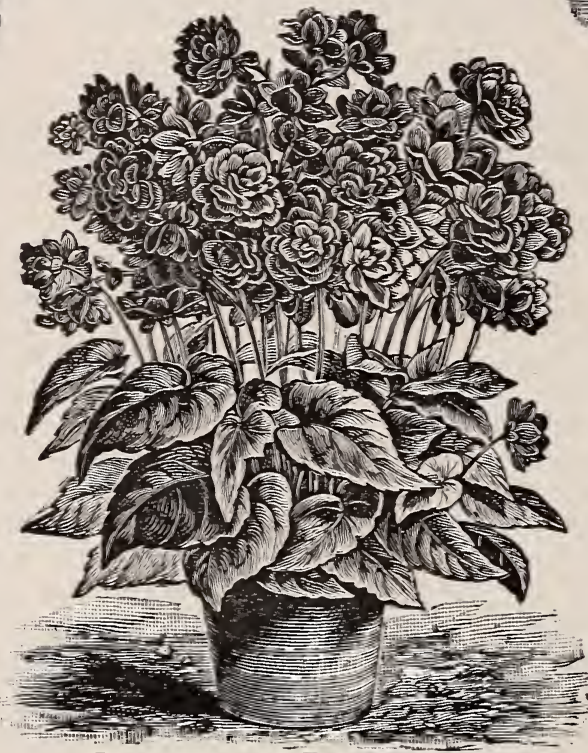

Begonia Duke Zeppelin.

Begonia Rubra-Tree-like in growth, often 8 feet high, enormous panicles of coral red flowers. $15 \mathrm{c}$. MAMMOTH TUBEROUS BEGONIAS The flowers are frequently six inches in diameter, and range in color from white to pink and through all the shades of rose, scarlet, orange and yellow, some being edged with different colors. Fine roots. $8 \mathrm{c}$. each, 4 for $25 \mathrm{c}$.

DOUBLE-FLOWERING BEGONIAS.

All the colors mentioned above are found among these. The flowers are often as double as roses and of most beautiful form. Grand pot plants. 10c. each, 3 for $25 \mathrm{c}$.

Begonia President Carnot-Handsome foliage; large cluster of waxy pink flowers. $15 \mathrm{c}$.

Begonia Alba Picta-Dark olive green leaves, with silver spots. 10c.

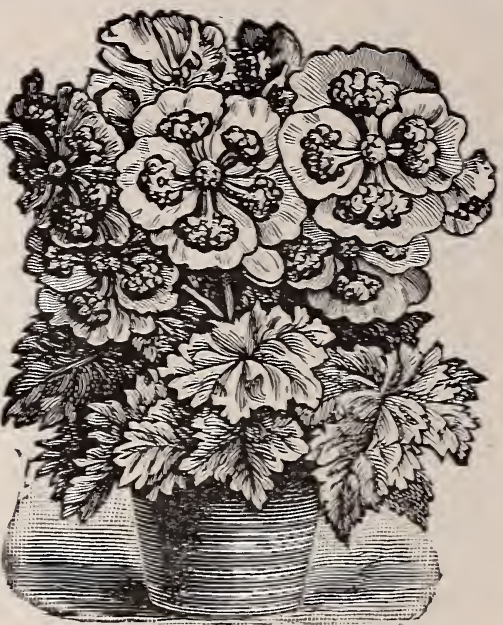

NEW CRESTED BEGONIA.

New Crested Begonia.-Note the curious maltese cross-like formation on the face of the flowers. This peculiar growth appears as if moulded in wax, and is certainly most remarkable. The foliage also shows a peculiar fringed and crested form. Very scarce. Price $40 \mathrm{c}$.

New Begonia, Duchess of Edinbnrg.-One of the most pleasing everbloomers. The flowers are very large, the $\pi$ hite centre edged by a band of deep blending pink. Extra fine. 15c.

Begonia A tropurpurea.-The foliage appears as if varnished and is of a very dark green color. Its large and numerous coral red iflowers are sure to make it ex-

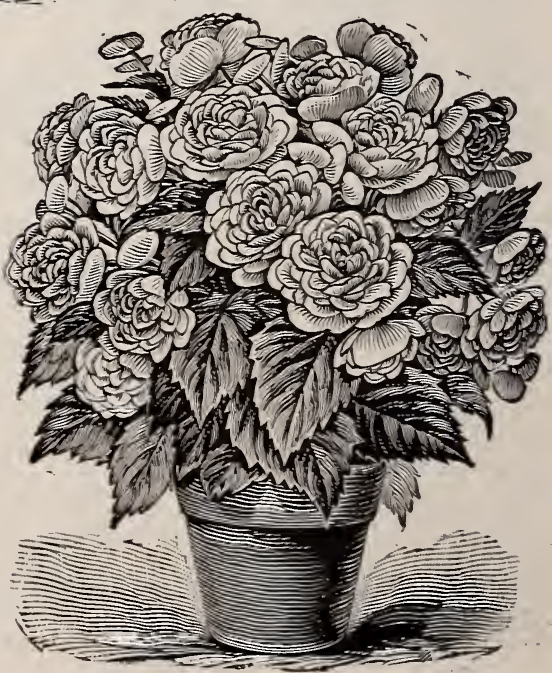

Double=flowering Begonias. 


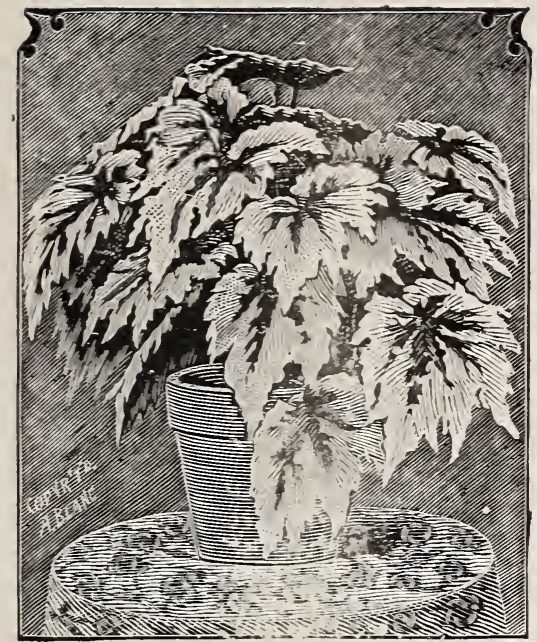

Fancy=leaved Begunia.

Fancy=leaved $B$ sgonias.

We have a fine assortment of the Fancr-leared Rex Begonias, so useful for indoor decoration at $15 \mathrm{c}$. each.

\section{NEW BEGONIA “BIJOU."}

This forms grand specimens in a short time. Its bright green foliage is profusely studded with right waxy-like crimson scarlet flowers. It blooms so freely that it should be included in every collection. $15 \mathrm{c}$.

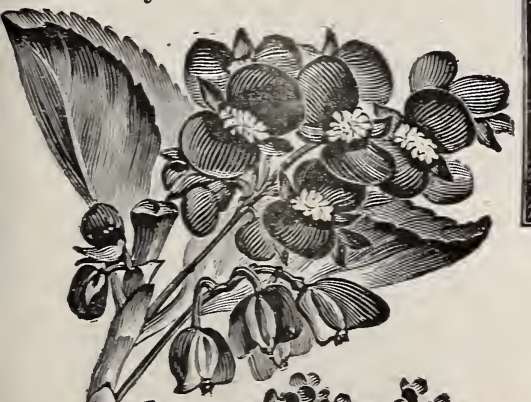

\section{W.}

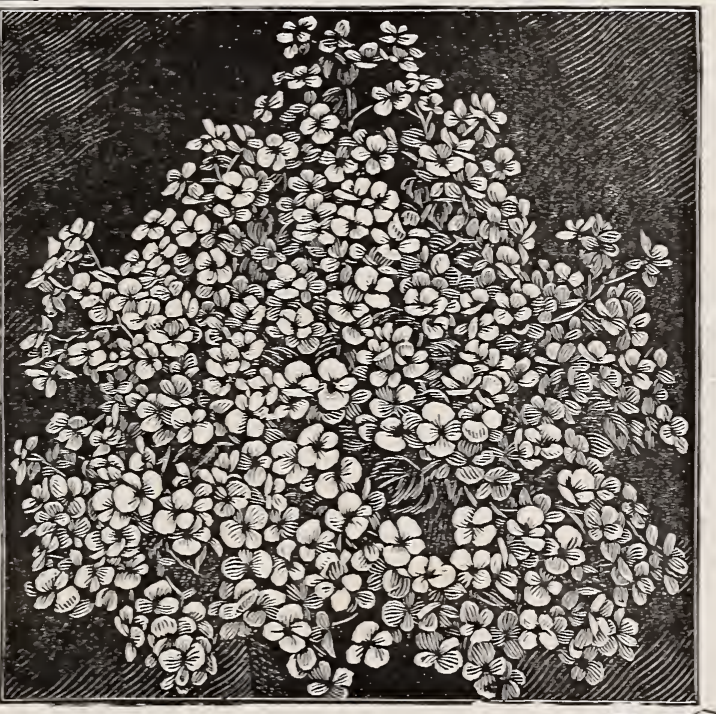

As an ever-blooming $\mathrm{Be}$ gonia this is the finest of all, not eren excepting Gloire de Lorraine, for the reason that: not only does it bloom just as freely, but it can be grown by the least skilled person, while G. de $L$. is a very difficult plant to manage. 'Pink Jewel begins to bloom at once; flowers and leaves appearing simultaneously and "forerer afterwards." As a pot plant it blooms all winter and literally covering the foliage. Extra fine plants 15̌c. up to 50c. Seed 10c.

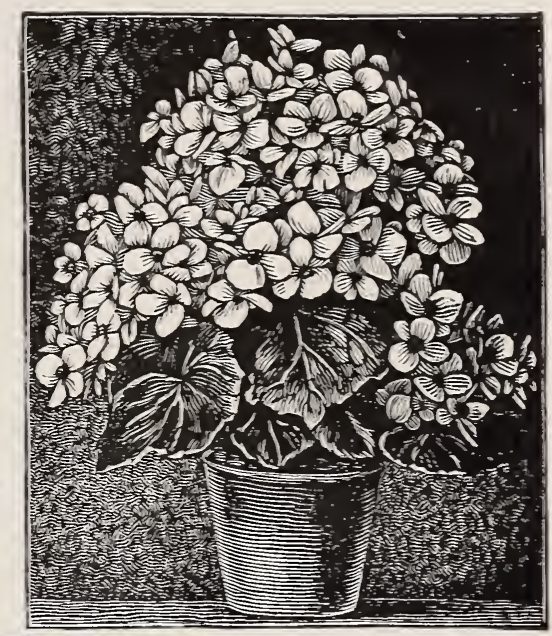

Begonia Gracilis.

NEW BEOONIA GLOIRE DE LORRAINE

While this is unequaled bs ans other Begonia in existence as a florist plant, it is by no means easily grown by amateurs. Try your hand at it and you may be rewarded if successful py specimens with hundreds of flowers of a deep rose, shading to lilac. Specimens 6 to 8 months old have been sold by the hundreds in Philadelphia at $\$ 5$ each. Price, small plants 50c., larger $\$ 1$ and upwards.

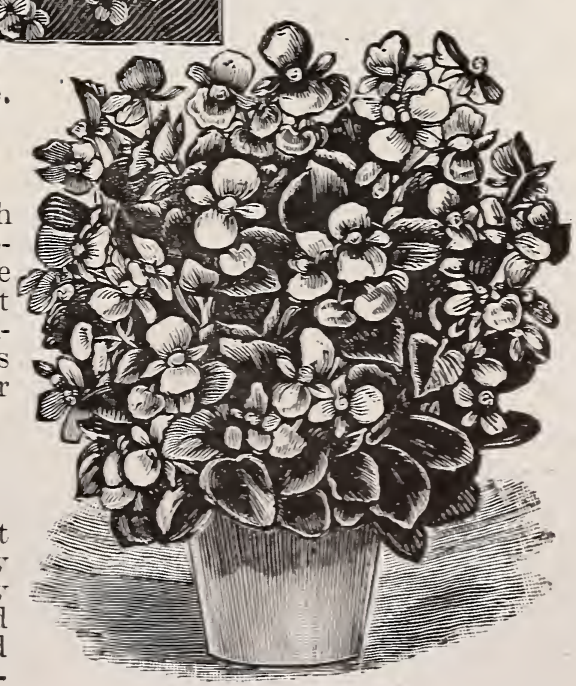

The Black Begonía.
New Everblooming Begonia Bijou.

Begonia Gloire de Lorraine. NEW BLACK BEGONIA " ZULU KING.'” A new German variety, with

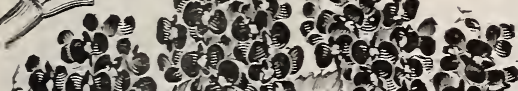

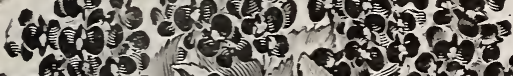

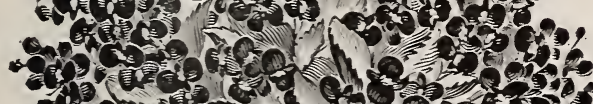
(i)

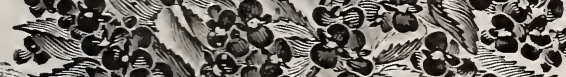

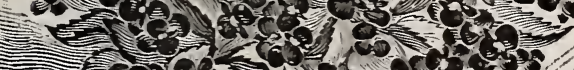

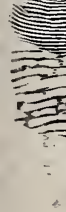

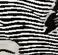
(6) pear almost black. The contrast with the bright red flowers is verr strik ing and always attracts and vers good grower. BEGONIA MANICATA AUREA.

Is perhaps the finest of all. The heary waxy blotched and spotted with creamy white and red hairs. A most beautiful plant. 20c. 
FICUS ELASTICA.- High-class decorative plant for room cuture. Leaves thick and leathery, dark glossy green, no other plant will stand as much ill usage; grows anywhere. 50 cents up to $\$ 5$.

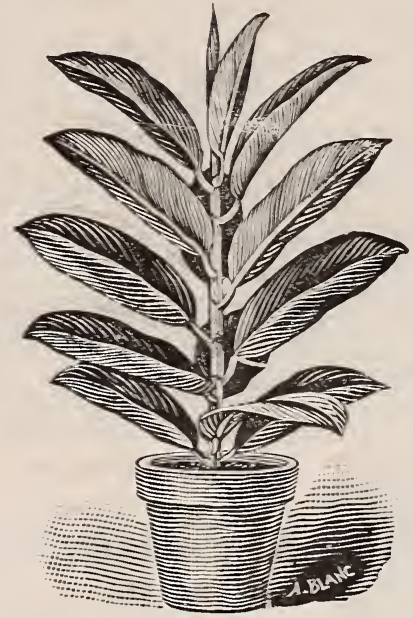

Rubber Plant.-Ficus Elastica.

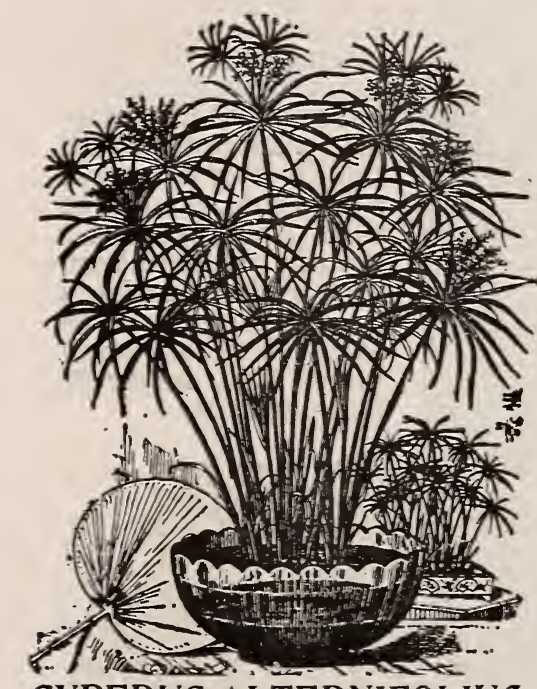

CYPERUS ALTERNIFOLIUS.

The Umbrella Palm is of the very easiest culture, if given plenty of water. Indeed it will grow in a bowl, dish or vase partly filled with soil and water. From the centre of the umbrella-like leaves appear small flow-

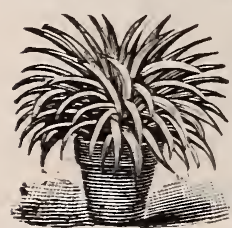

Pótartettia. ers, followed by young plants. 2oc. t POURRETTIA. Valuable room plants. Stand illtreatment. Graceful leaves, silvery below; scarlet inflorescence. $20 \mathrm{cts}$.

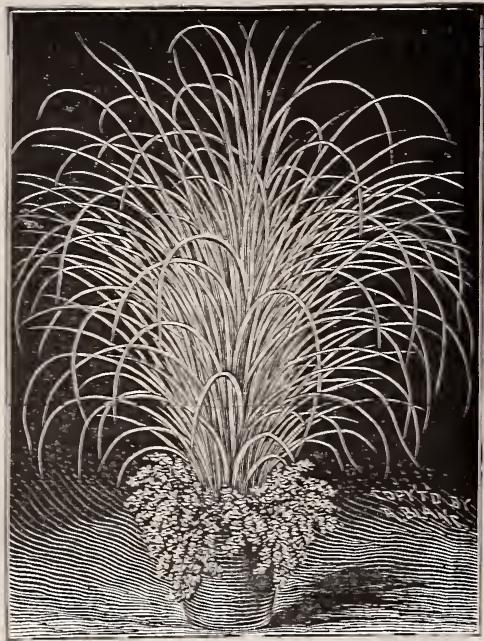

NEW CAREX JAPONICA.

First-class novelty, and an excellent table decorative plant. The fine delicate leaves, edged as with a band of gold, are most gracefully recurved and perpetually in motion; hence, without the stiffness of so many other plants used as table ornaments. A gem for jardinieres. Useful for many purposes. 20 cents; large clumps, 50 cents.

\section{EUPHORBIA ARBOREA.}

Exceedingly ornamental, rapid growing. In three years will grow I5 feet high and 8 feet through and become very valuable. Has sold at \$Ioo! I5 cents, by mail; or larger, 50 cents to $\$ I 0$.

DYCKIA SULPHUREA.

Miniature Century Plant. Blooms when one year old. Fine spikes, 2 to 3 feet, deep golden flowers. 20 cents to $\$ I$. SPECIAL OFFER. - I Pourrettia, I Carex, I Croton, I Cyperus, I Areca, I Euphorbia, for $\$ 1.25$. A fine collection of plants.

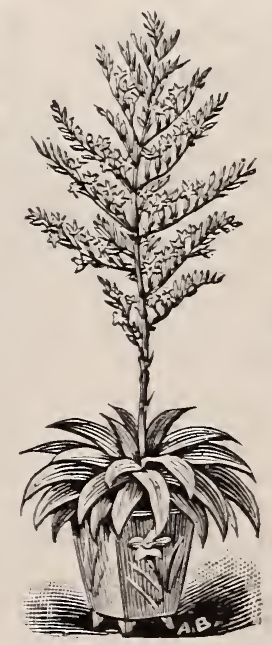

Dyckia.

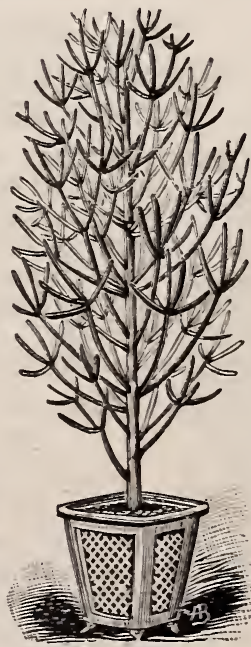

Euphorbia.

\section{CROTONS.}

Extremely beautiful; leaves of all forms, upright, drooping, twisted ; variegated in hundreds of colors, yellow, green, red. 40 sorts. A plant that will please you. 30 cents to \$I.
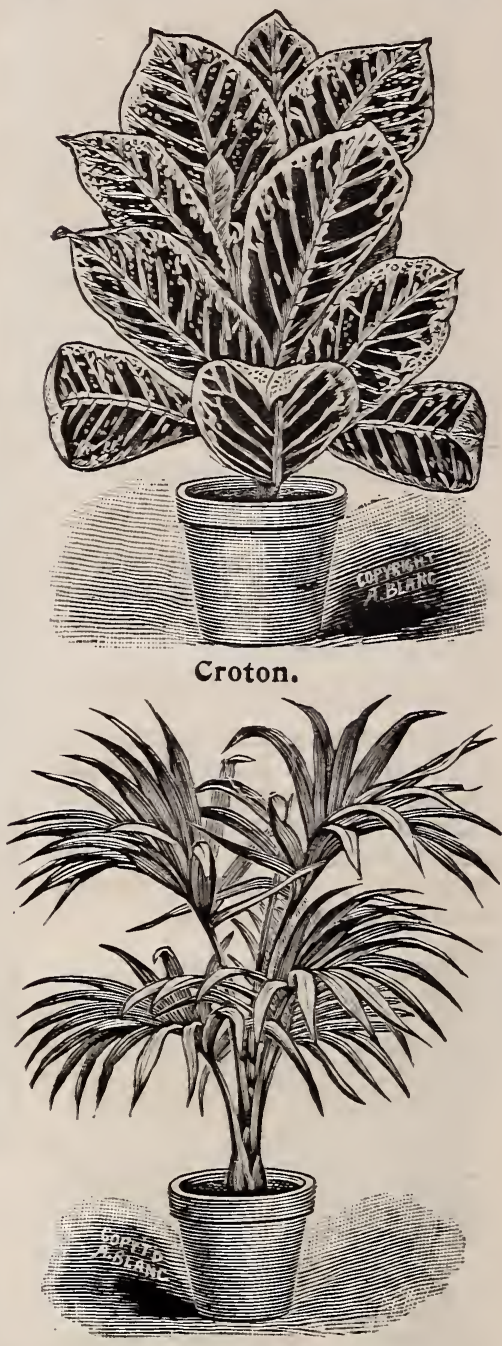

ARECA LUTESCENS.

Most beautiful, delicate feathery foliage, and golden yellow stems, spotted with red. The best of all house palms. 25 cents to $\$ 5$. Every one should have it. Other fine palms are : Cocos Weddelliana, very graceful, 25 cents. Kentia Balmoreana, 35 cents. Latania Borbonica, 25 cents. All plants that will please you.

\section{Special Offers :}

Any four I5-cent plants for 50 cents, or Io for \$I. Any three 20-cent plants for 50 cents, or 7 for \$I. Any three 25 -cent plants for 60 cents, or 6 for $\$ 1$. 


\section{EASTER CACTUS.}

New Crab Cactus, distinct from any other. Always in bloom by Easter; very brilliant scarlet flowers. 20 cents to $\$$ I.

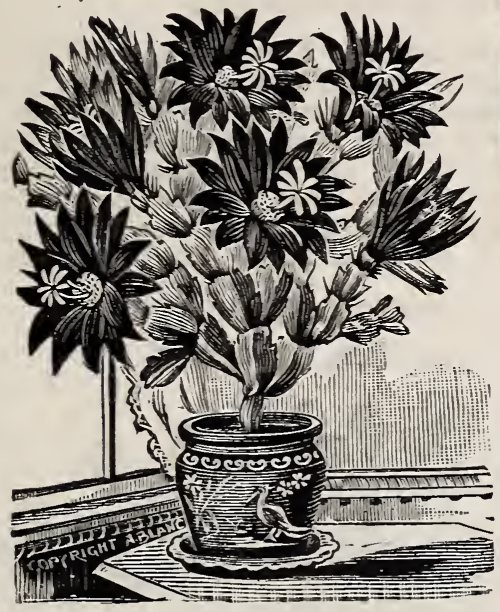

Easter Cactus.

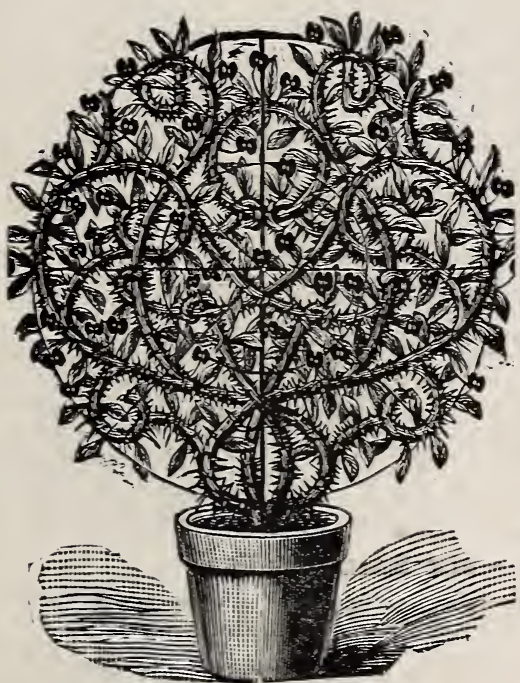

Euphorbia-Crown of Thorns.

\section{CROWN OF THORNS.}

We have seen the most beautiful specimens imaginable of these plants, trained in ornamental and complicated forms; highly valued by the owners. Our cut shows one of them; you can do likewise. When full of scarlet flowers and covered with green foliage they are certainly grand. A plant that will please you. Price, 20 cents to $\$ 2$; cuttings, Io cents. Five rare Euphorbias, all distinct, \$I.

700 varieties of Cacti in stock.

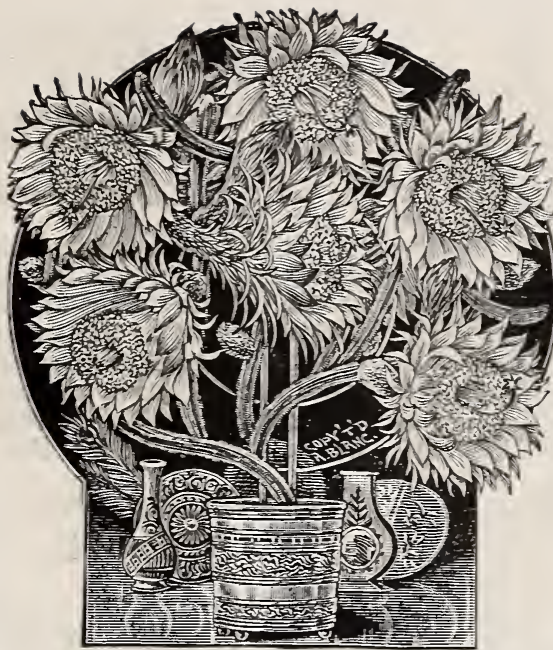

\section{QUEEN OF THE NIGHT.}

Most glorious of all the Cacti opens after sunset; flowers I2 to I4 inches, white and yellow, exceedingly fragrant. Grandest flower in existence. A plant that will please you. Three kinds, 20 cents up to $\$ 5$ each. 700 Distinct Cacti in Stock. 6 Cacti, nice plants, by mail, 50 cts. I2 Cacti, rarer sorts, all different, \$I. 25 Cacti, some large, all different, $\$ 2$. 50 Cacti, a fine collection, rare, \$5.

Special Cacti Catalogue Free. Book on Cacti.

Ioo pages, I6o life-like illustrations, Io cents. Sells in Europe at \$I.

Io Cacti, ro Japanese Porcelain Flower Pots.

In Io varieties, with or without soil, as desired, labels, book, etc., by express, for $\$ 3 ; 5$ for $\$$ I. 5 o.

\section{Large Century Plants.}

20 sorts, 50 cts. to $\$ 2$ each, by express.

Send us the names of your friends who grow flowers; we'll send them our Catalogues and won't forget you.

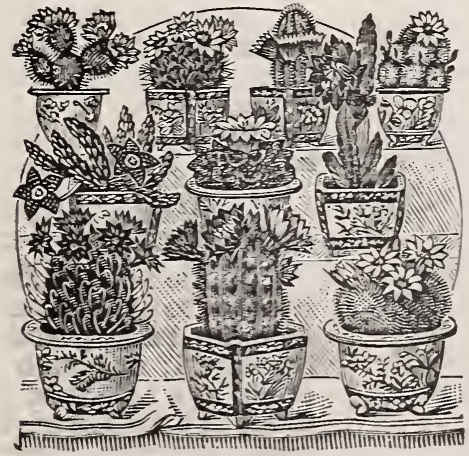

10 Cacti in Japanese Pots, $\$ 3$.

\section{YELLOW FLOWERING CACTUS.}

Very rare, tall, upright growing. Very large flowers, of pale lemon yellow, and very fragrant, 30 cents; white, pink and red, 20 cents to $\$ 2$.

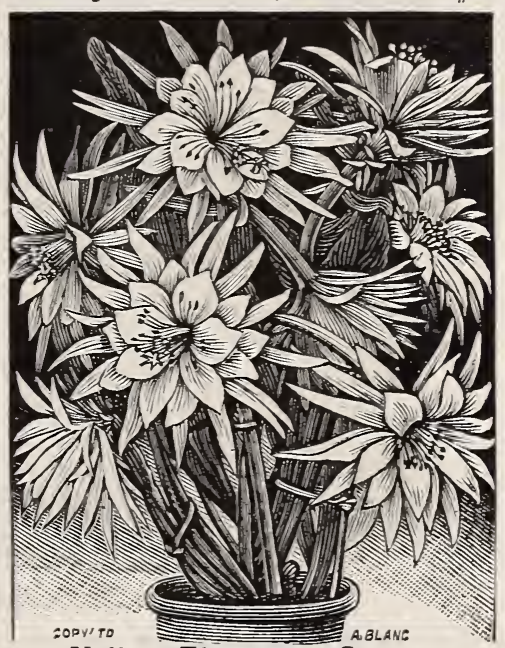

Yellow Flowering Cactus

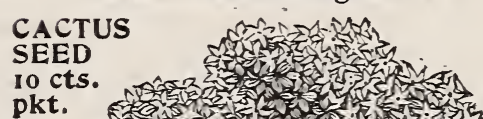

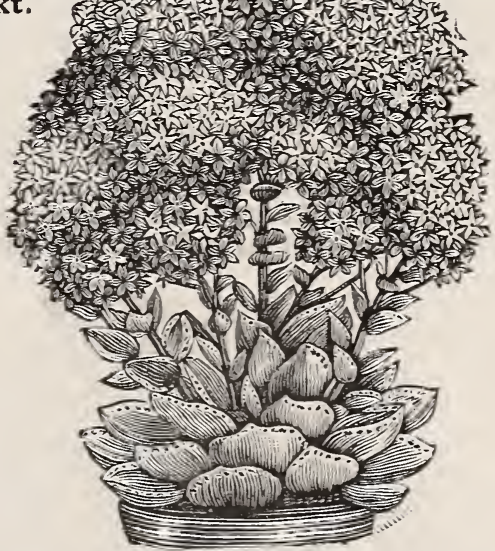

CRASSULA-Winter Beauty.

Here is an excellent succulent plant for winter blooming-never misses to reward you with dense clusters of pink and white fragrant flowers, lasting ever so long. Price, 20 cents.

CENTURY PLANTS.

20 Rare Sorts.

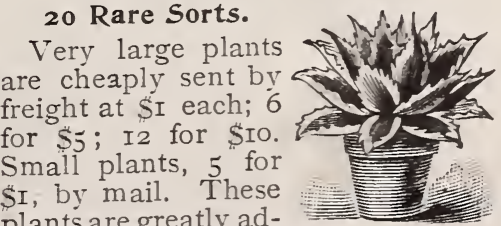
plants are greatly admired Seed, 8 cts. Century Plant. 


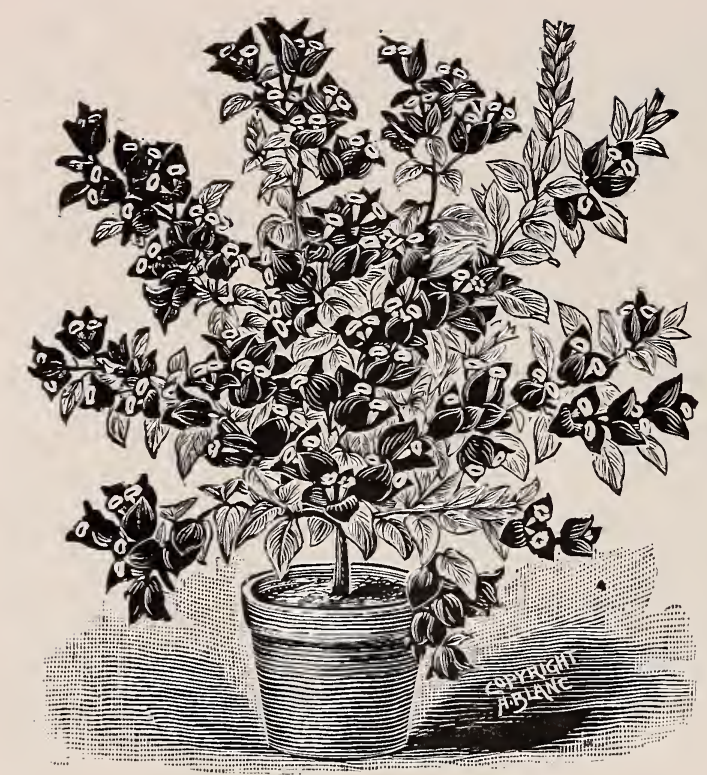

Bougainvillea Sanderiana.

\section{BOUGAINVILLEA SANDERIANA.}

We have grown this most useful flowering plant in a greenhouse, where it has continued flowering for seven months, small and large plants alike being covered with blossoms from May until December. It produces as freely as a fuchsia, its dazzling, rosy, crimson flowers lasting Iong in perfection, even if grown in smallest pots, under all conditions, in amazing profusion. Awarded first-class certificate by the Royal Horticultural Society, and only recently introduced at $\$ 2$ each. It cannot fail to give you satisfaction. Our price, 25 cts.; 3 for 60 cts.; larger plants, $\$$ I.

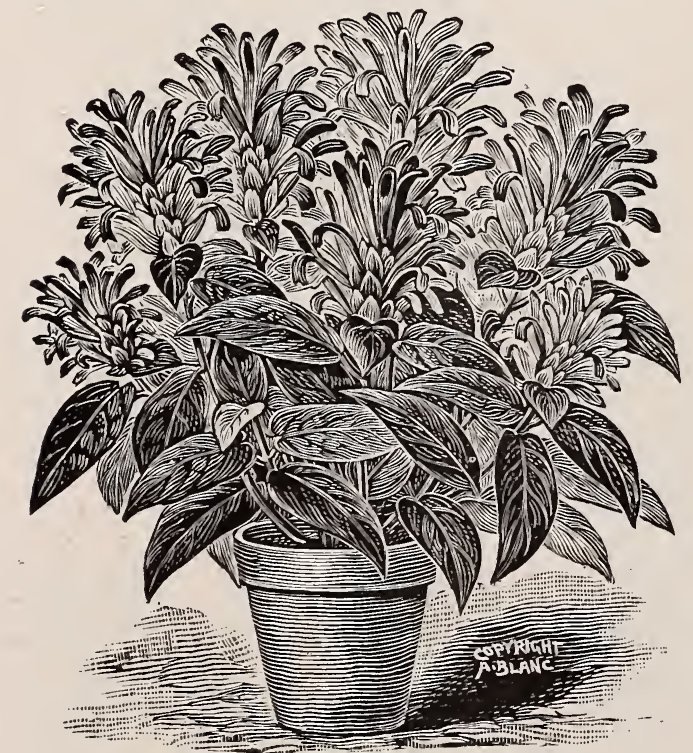

New Dwarf Justicia Velutina.

\section{Three High=Class Novelties. THE SHATIROCK PEA.}

\section{Parochetus or Blue Oxalis.}

It's just an elegant little beauty. Leaves like an Oxalis; dark, emerald green, frequently marked with a peacock eye, as shown. Upon them trail gracefully, glistening like a mosaic, the divine flowers of the deepest cobalt blue, set off with a pink centre. Not another flower like it. It's a real sparkling little jewel, which grows as readily as an Oxalis, and is in bloom the whole year round. A charming rock plant, and more desirable for pots or baskets. Price, 25 cents each. Seed, ro cents.

The three Novelties illustrated, for 60 cents. With Vitis Coignetiæa, 80 cents.

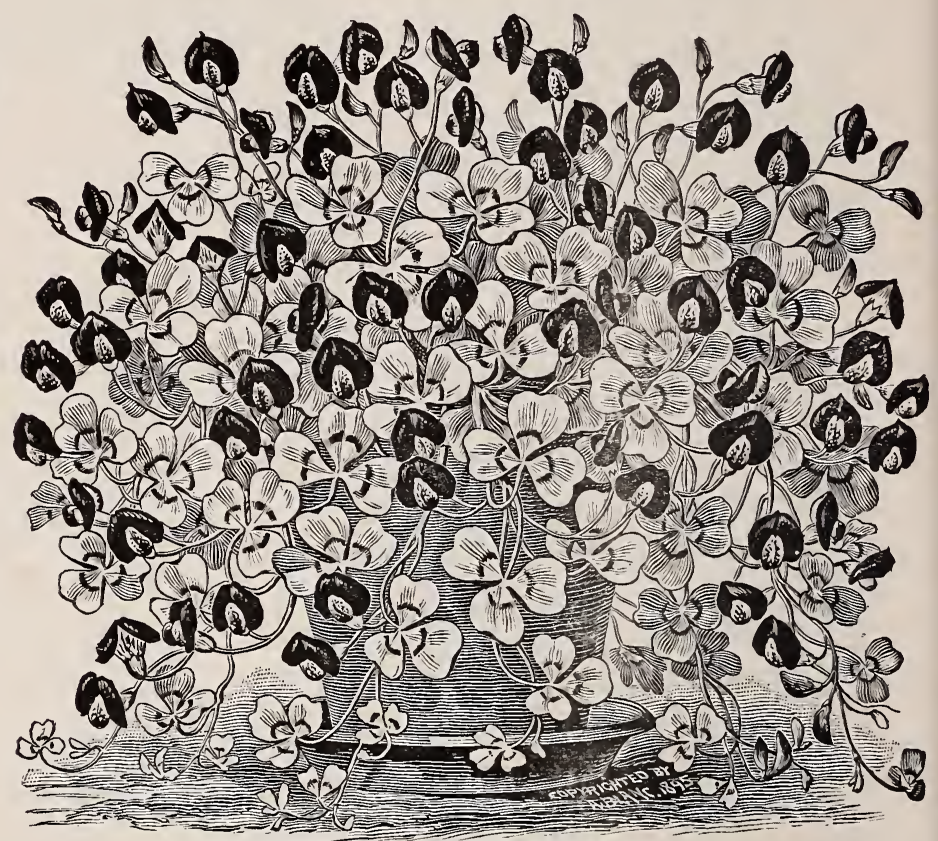

Parochetus-The Shamrock Pea.

\section{NEW JUSTICIA VELUTINA.}

A New Dwarf Justicia, grown extensively by Parisian florists, for garden and table ceco an. When only a few inches high it begins to bear clusters of large, pink, feather-like Howers, lasting for a long time, and is never thereafter out of bloom-frequently fifty spikes at ore time. An excellent novelty. Of easy growth. Highly prescd. Price, 20 cents.

\section{"ASPARAGUS VERTICELLATUS."}

The Hardy "Climbing Asparagus Sprengeri."

While not absolutely new, this rariety is considered rare enough to have been offered this year at $\$ 15$ per plant. It has the same grand habit and appearance as Asparagus Sprengeri; although much finer in texture, and will easily climb to a height of 10 to 12 feet. TThen covered with hundreds of bright scarlet berries it is a wonderful ornament for porch or trellis. The roots are perfectly hardy even in Philadelphia. Stock limited. 50c. each; 3 for $\$ 1.25$; seed 20 c. 


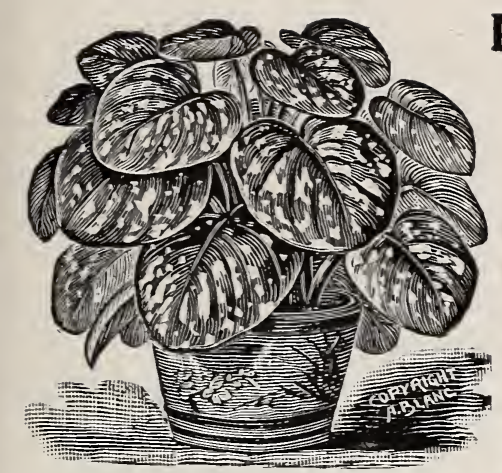

FARFUGIUM GRANDE.

The leaves become immense; clear bright green, heavily blotched with golden yellow. Fine yellow flowers. From China. We recommend it. 25c.

\section{MARANTAS.}

Very valuable room plants, forming magnificent specimens. Leares metallio green, splashed, reined and striped in many combinations, such as gray, olive, maroon, etc., usually red underneath. 20c.

\section{PELLIONA DAVEAUANA.}

This comparatively new plants comes to us from Cochin-China. Our small cut does not do it justice by any means. We've had plants $9 \mathrm{ft}$. in circumference, drooping $3 \mathrm{ft}$. below the pot. The leares are thick and leathery, of a silvery grar, mottled and marbled with dark green and covered with purple lustre, the under part red. Fine room plant. $20 \mathrm{c}$.

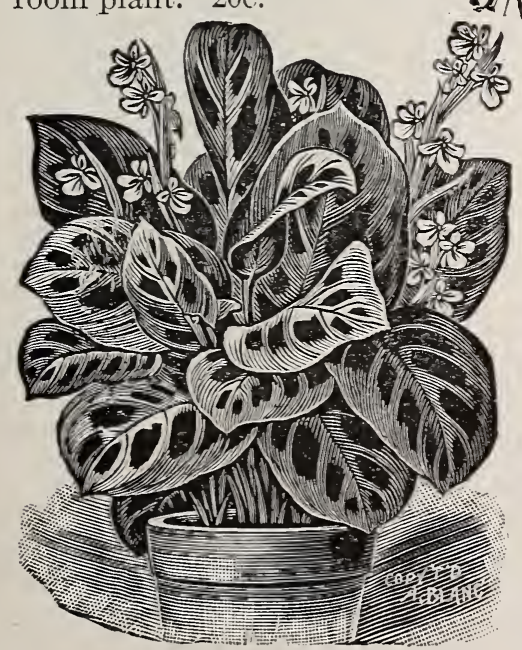

Marantas.

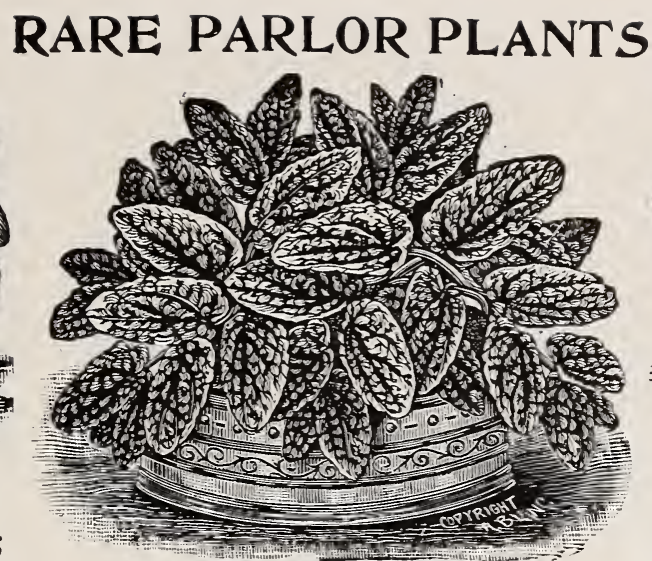

Pelliona Daveauana.
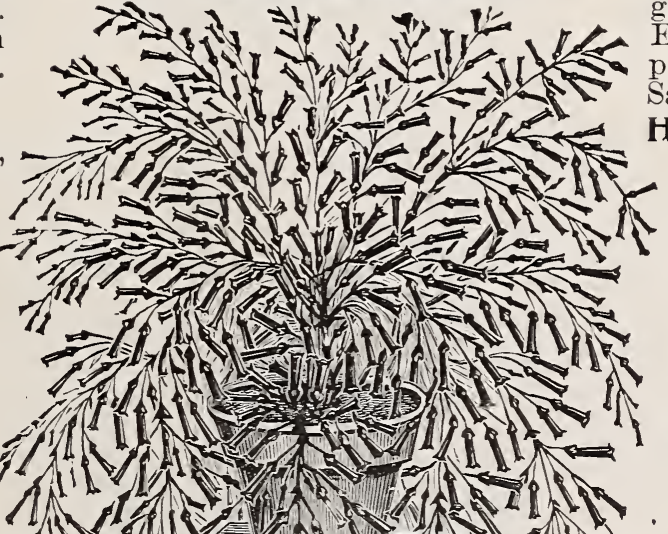

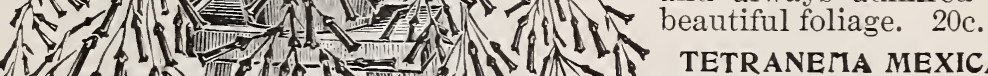

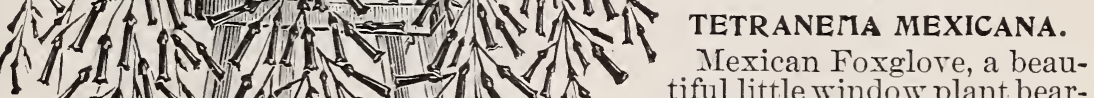

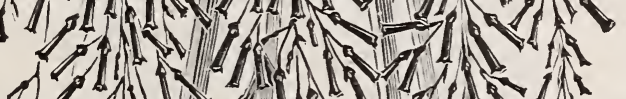

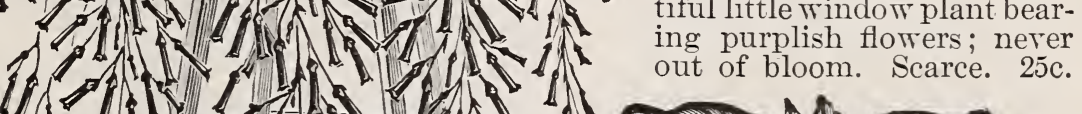

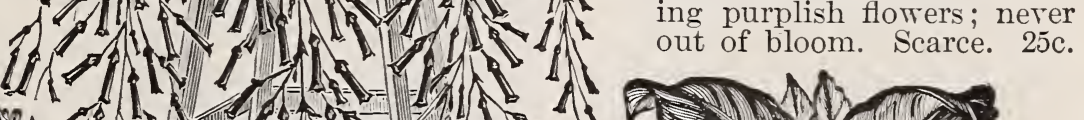

\section{SILVER PEPEROMIA.}

Leaves thick and waxy-like, silvery gray, with metallic green stripes; most beautiful. Excellent for dinner table or Sandwich Islands. 25c HOFFMANNIA DISCOLOR A rare and beautiful plant oft and shining like velvet. crimped and of a dark olive green, with white veins; the under part rich red wine color with carmine reins. The along the leaf stems. This plant grows well for anybody even in unfarorable places of $10=2$

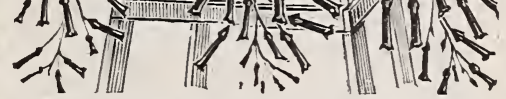
NEW RUSSELIA ELEGANTISSIMA Scarlet Fountain.

Here is certainly a fine new plant that you should not be without. It's another of $\lambda$ r. Lemoine's scientific works, and a rast improvement of the old Russelia. The habit is drooping as shown, the slender branches and leaves being completely hidden by hundreds of the vivid scarlet tubular flowers. It is so floriferous that tiny cuttings show more flowers than leares. It is one of the finest and best new plants ever introduced and one that will give satisfaction to everyone. 20c. 2 for $30 \mathrm{c}$.

The 6 Plants here illustratrd for $\$ 1.10$.

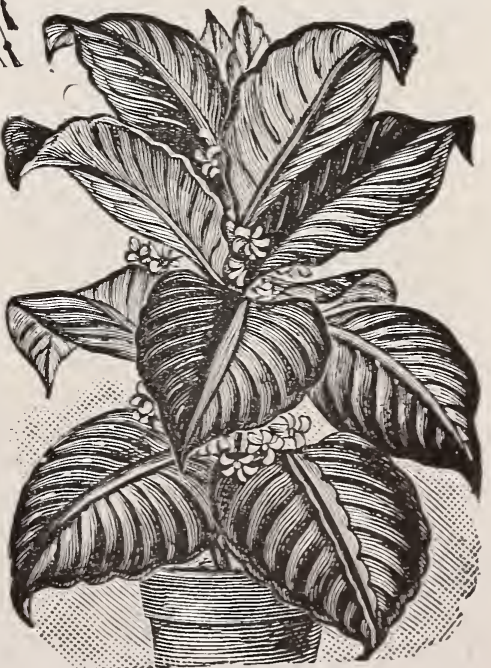

Hoffmannia Discolor. 


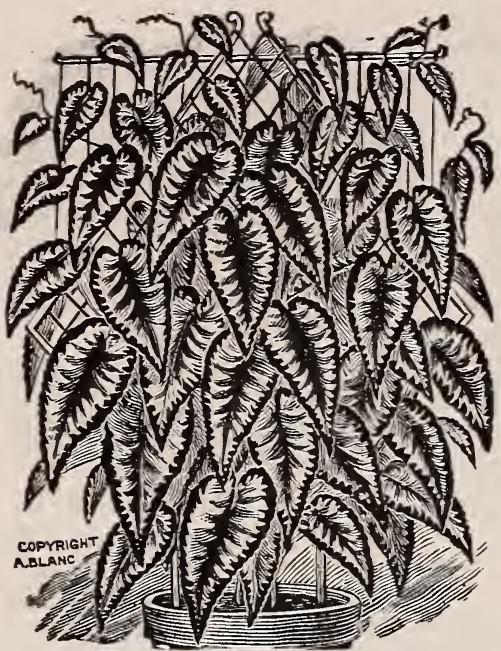

Cissus Discolor. (Chameleon Vine.)

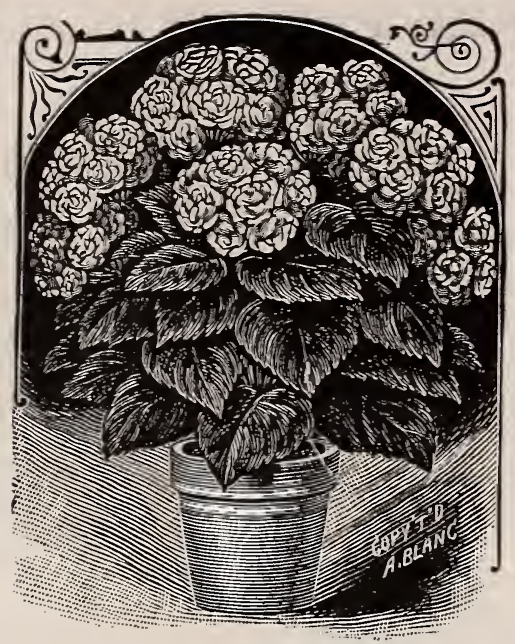

Fragrant Clerodendron.

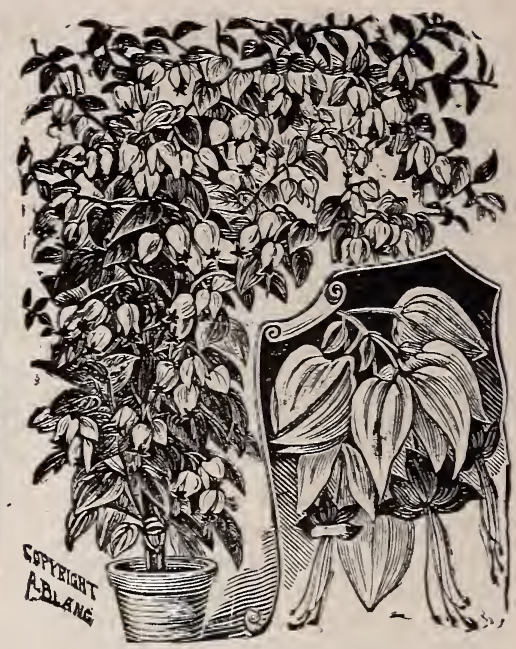

Clerodendron Balfouri.

CISSUS DISCOLOR. (Chameleon Vine.) The leares are long, heart shaped and even more beautiful than the finest Rex Begonias. The midrib and fluted edges are cinnabar red. The rest of the upper surface is silver and bronze green, and olive green towards the midrib. The under side a rich wine red. As a house plant nothing is more gorgeous, but it requires a rather warm place. $15 \mathrm{c}$.

CLERODENDRON FRAGRANS. A bold looking plant, growing close and compact like a geranium for which the large dense clusters of waxy white flowers are sometimes mistaken until their perfectly delightful jessamine-like odor is discovered. One of our most popular plants. 20c.

CLERODENDRON BALFOURI. As a continuous bloomer we do not know of a better plant. One of our stock plants, has never been out of flower for six years. Can be grown as a climber in green house or outside, but is not hardy. If cut back frequently it will grow in bush form and cover itself with beautiful white and crimson flowers which remain a long time.

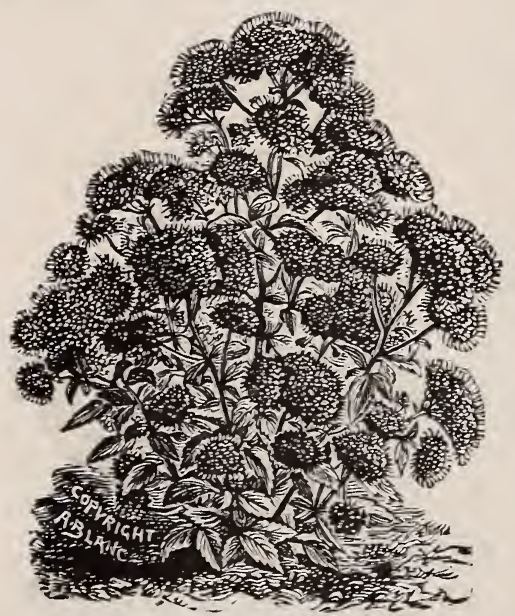

Caryopteris, Blue Spiræa.

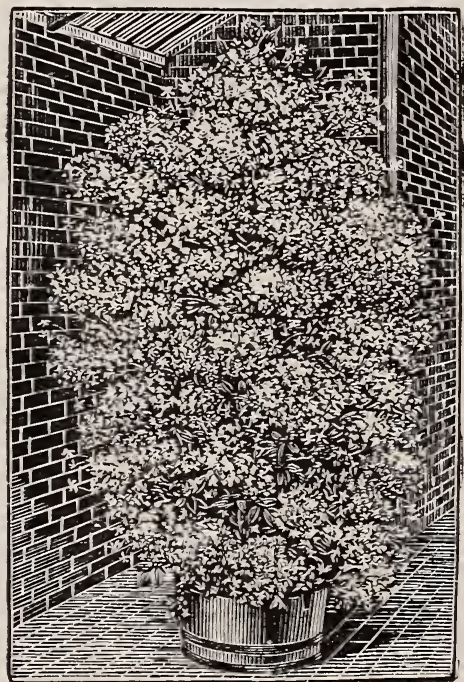

Confederate Jessamine. Extra good. 15c.

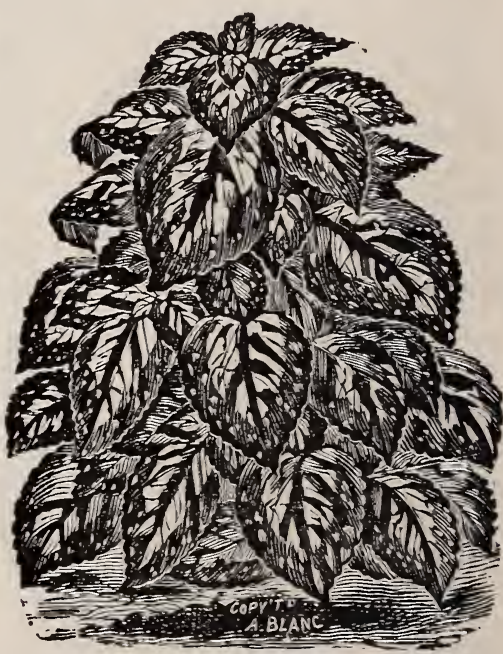

Royal Coleus.

t CARYOPTERIS. (The Blue Spiræa.) This, our own introduction from China, is admitted by all authorities to be one of the finest new hardy plants ever introduced. It forms a bush about 2 feet ligh, blooming profusely from June until December. Its a fine bee plant. $15 \mathrm{c}$. The new white $20 \mathrm{c}$.

CONFEDERATE JESSAMINE. (Rhyncospermum Jasminoides.) Our illustration shows what a grand specimen can be had by carefully growing and training. The foliage is dark and evergreen. The pure white flowers have a powerful and exquisite fragrance. Always in bloom. Large plants 35c.

ROYAL COLEUS. We have a fine assortment. Customers leaving selection to us are sure to receive something that will please them. Prices 10 and 15 cts. Dozen or hundred quoted accordingly. 


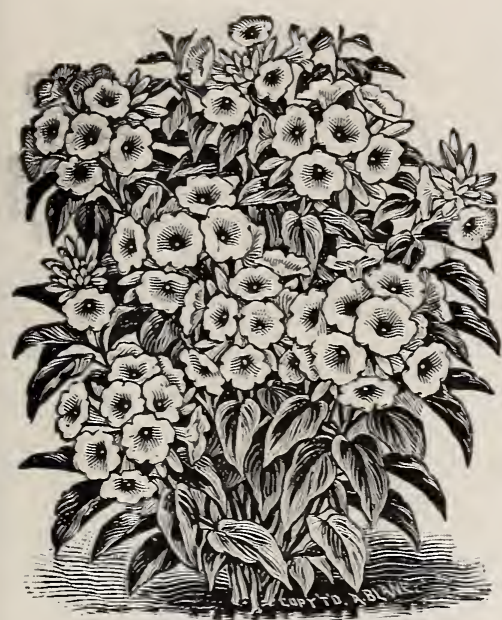

Tree Morning Glory.

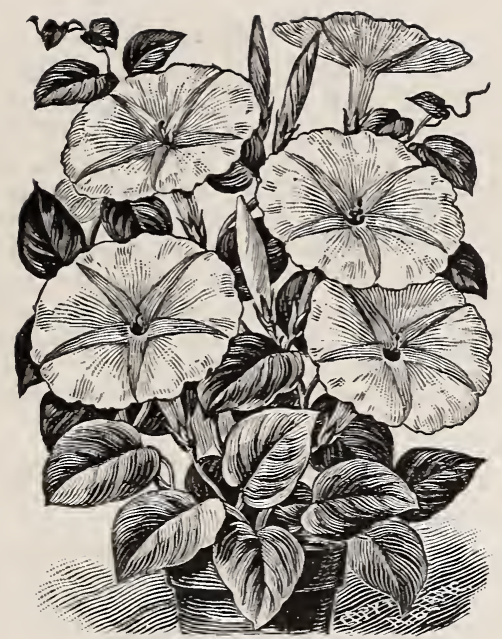

Giant Moonflower.

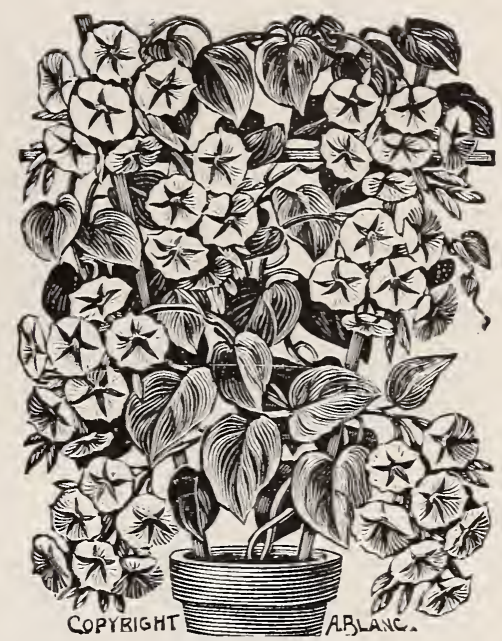

Golden Ipomæa.

THE GIANT MOONFLOWER.

Entirely new. Described by the originator as bearing white flowers 6 to 8 inches across. More robust in growth (sometimes $40 \mathrm{feet}$ ). 5 P.M., and close at about to the following morning. More fragrant than jessamine or orange blossoms. Distinct. Highly ornamental. 20 cents; seed, Io cents. THE TREE MORNING GLORY.

Grows in bush-like form, blooming richly from July until winter, and then indoors, if wanted. Flowers a beautiful rose, spotted with purple, borne in clusters. Needs full sun. (Originator's description.) All plants mailed free. 20 cents; seed, Io cents. GOLDEN MORNING GLORY.

Dense clusters of bright golden yellow flowers, even in the depth of winter. Last year, $\$ 1$ each. Our price, 20 cents. Purple Mexican Ipomæa.-A thousand blossoms a day is not unusual from strong roots. Flowers deep purple. I5 cents. These four morning glories, 60 cents.

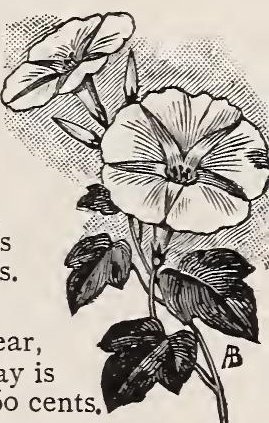

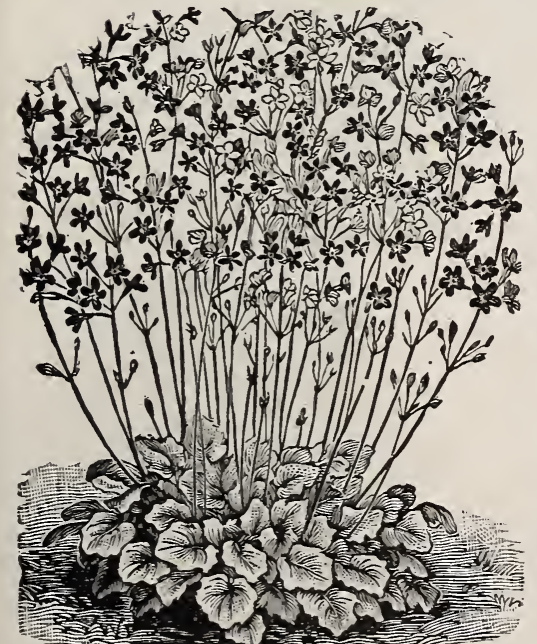

HEUCHERA SANGUINEA.

Crimson Bells, in graceful clusters, on slender stems, waft gently in the air above rosettes of nicely variegated foliage ; and they are used for cutting, too. Perfectly hardy. Noted by the American Florists' Society as one of the 6 best red flowering plants. Distinct. I5 cents; seed, IO cents.

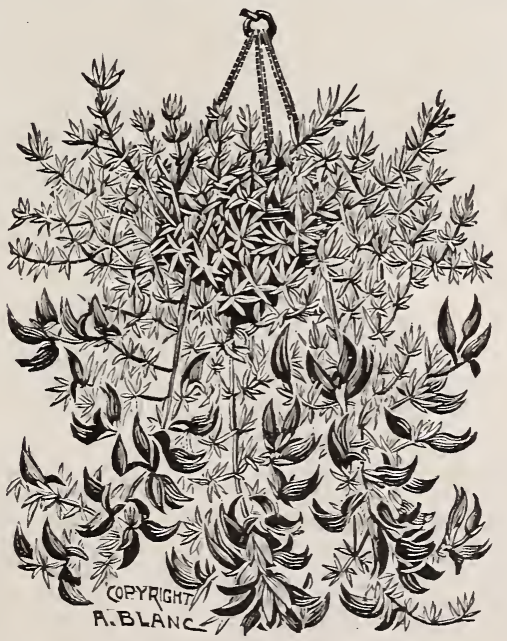

LOTUS-Coral Gem.

Nothing prettier under the sun for a hanging basket. Delicate silvery green feathery foliage, drooping in a most graceful manner, and, when in flower, a grand sight, the brilliant, dazzling crimson buds resembling some quaint orchid. Pretty, whether in bloom or not. Price, I5 cents.

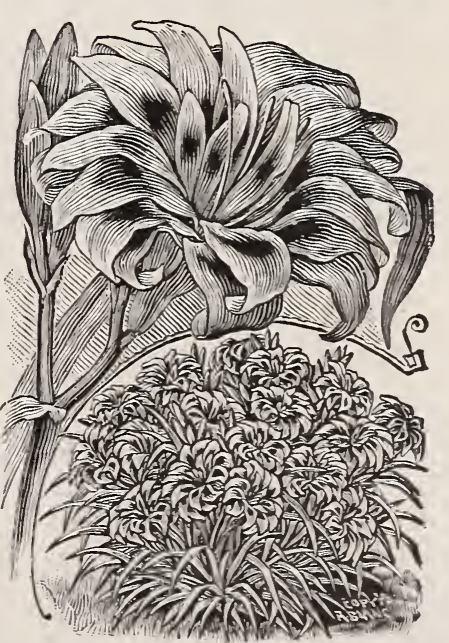

DOUBLE GOLDEN CROWN.

The double Hemerocallis is certainly a most beautiful flower, and it is strange that it has not been brought forward more prominently. Large golden yellow double flowers, with a carmine ring toward the centre. Perfectly hardy garden plant. Seed of eight sorts, mixed, ro cts. Plant, 20 cts. 


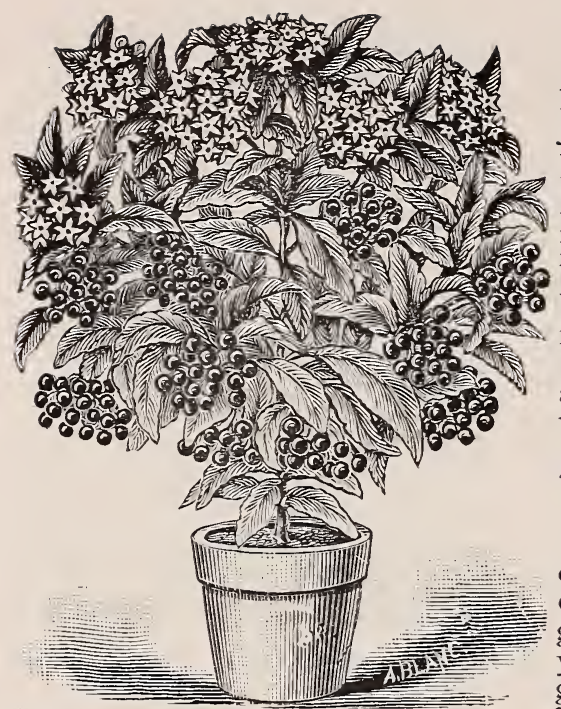

ARDISIA CRENULATA.

Christmas Berries. A Jap-

anese plant of great value. The foliage is very leathery. The flowers are small, sweet-scented and wax-like ; these are succeded by heavy clusters of bright red, shining berries, which remain langing on the branches not for months, but for years. Large specimens are truly handsome. 25 cents ; larger plants, 50 cents to $\$ 2$; seed, Io cents.

\section{ANTHOLYZA BICOLOR.}

A bulb from the Cape of Good Hope, as easy to grow as a gladiolus and producing charming red and yellow flowers on long stems. Started bulbs, Io cents; 3 for 25 cents.
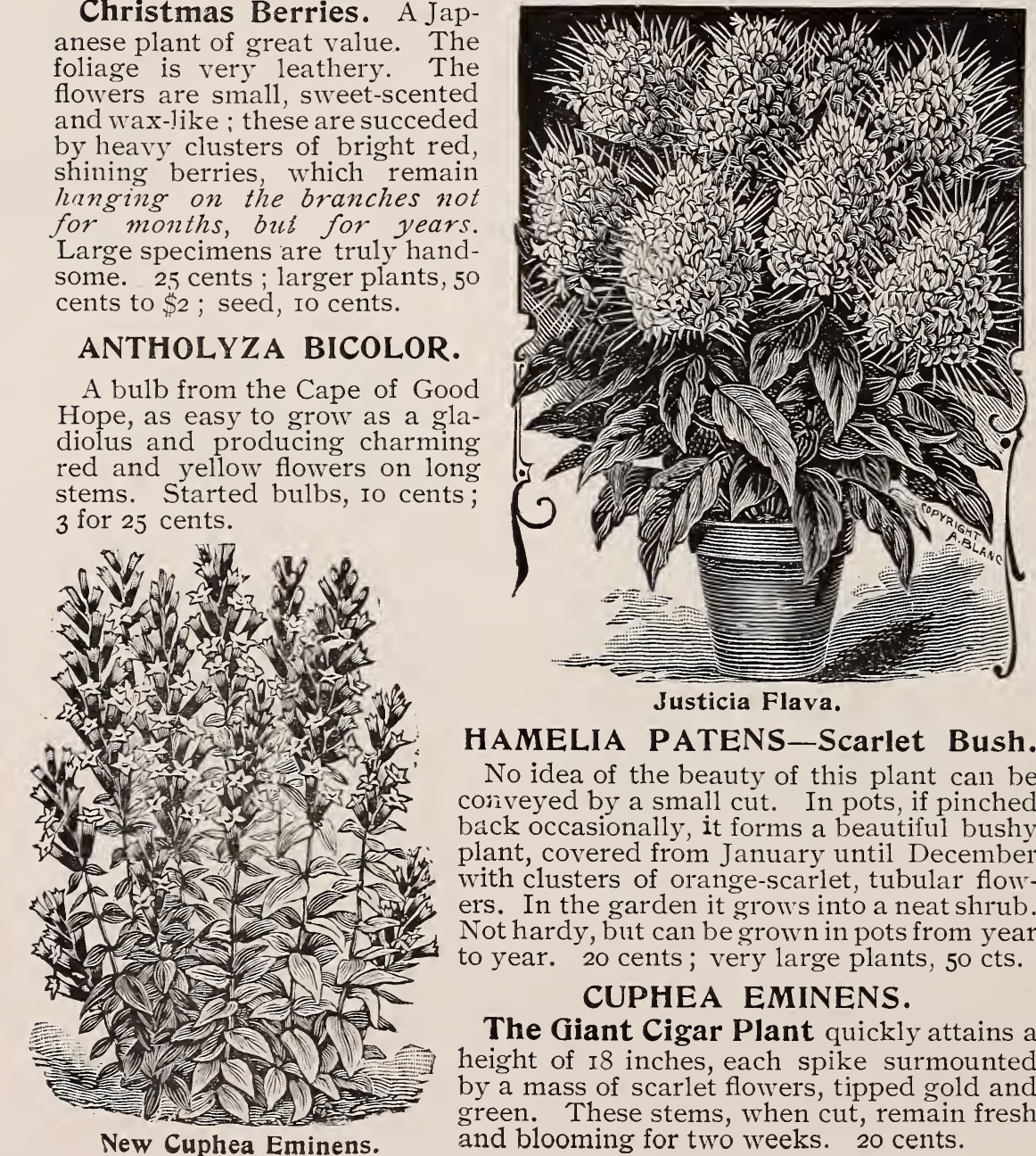

HAMELIA PATENS-Scarlet Bush.

No idea of the beauty of this plant can be conveyed by a small cut. In pots, if pinched back occasionally, it forms a beautiful bushy plant, covered from January until December with clusters of orange-scarlet, tubular flowers. In the garden it grows into a neat shrub. Not hardy, but can be grown in pots from year to year. 20 cents; very large plants, 50 cts.

\section{CUPHEA EMINENS.}

The Giant Cigar Plant quickly attains a height of 18 inches, each spike surmounted by a mass of scarlet flowers, tipped gold and green. These stems, when cut, remain fresh and blooming for two weeks. 20 cents.

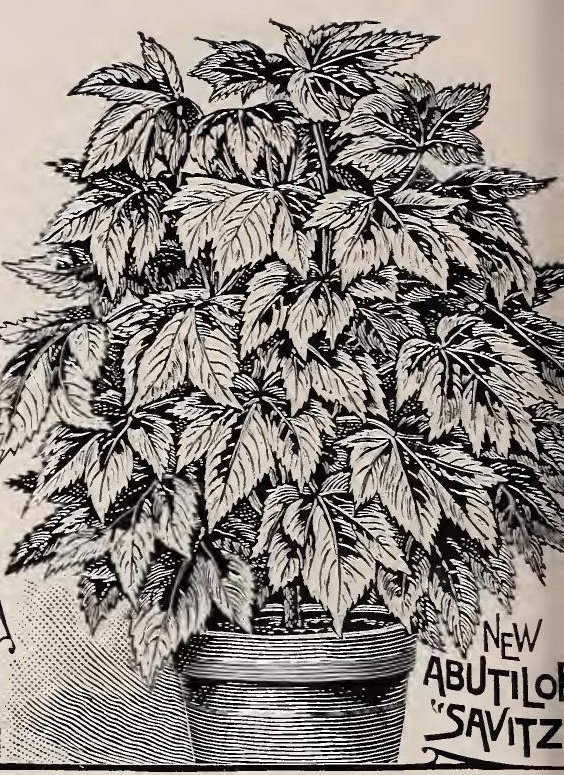

\section{ABUTILON SAVITZI.}

Green and White. One of the most beautiful new variegated-leaved plants in existence. Its large, maple-like leaves are almost white, being blotched here and there only with clear bright green, a most charming contrast, heightened still more by the very large, orange, bell-shaped flowers with which the plant is always covered. This is one of our very best novelties, both for garden as well as for growing indoors. 20 cents.

NOTE. -We will send the 7 plants on this page for $\$ I$.

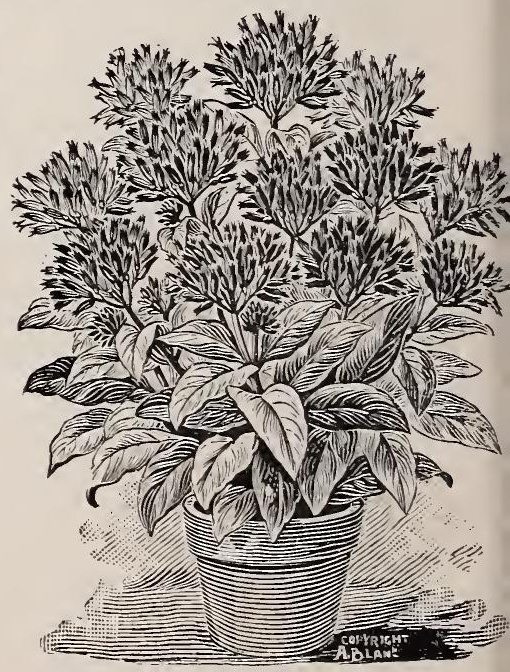

Hamelia Patens. 
GERANIUMS.

Alfred Tullet. A new sort just received from England, where it is considered the finest and largest single scarlet grou'n. An excellent out-door bedder. $15 \mathrm{cts}$.

Fleur Poitevine. Extra largesingle flowers, of a brilliant rosy carmine, elegantly striped with white. Centre orange scarlet, very dwarf grower. 15 cts.

Mrs. A. Blanc. This is Mr. Bruant's best introduction in this color. A pure apricot salmon with rose centre. The size of the flowers is enormous. $15 \mathrm{cts}$.

L'Aube. The best of all the French whites to date. Immense trusses borne on erect stems. $15 \mathrm{cts}$.

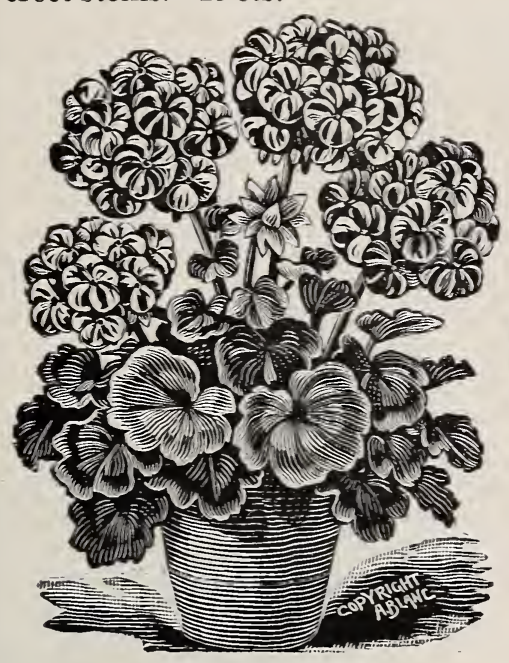

\section{SINGLE NEW LIFE} GERANIUM.

Introduced nearly 20 years ago at $\$ 5$ per plant. This has been entirely lost in this country until now. The flowers are vers large, single some are white, some all scarlet, others striped white and scarlet; sometimes an entire spike is red, another all white. 20 cents, or with Double New Life, 30 cts.

\section{PANSY GERANIUM.}

Mme. Braunt. Another grand novelty. Flowers large, irory-white, veined with lake, blending into a beautiful aureole of bright solferino. 20 cts.; the 3 Geraniums, $55 \mathrm{c}$.

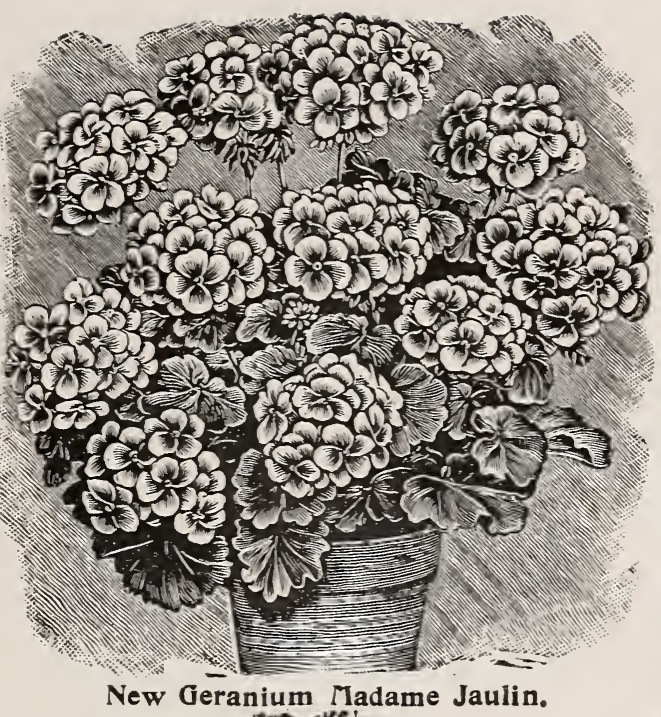

Madame Jaulin. Centre of flower delicate pink, surrounded by large band of white. Decidedly attractive. Semi-double. 15 cts.

\section{PELARGONIUM. Smith's Pride.}

Great strides have been made in Pelargoniums, but this is decidedly the finest of all, and is now offered for the first time. Besides being exceedingly dwarf, the plant begins to bloom when only a few inches high, bearing large globular trusses of flowers resembling immense Azaleas. The blending of white, pink, carmine, or maroon, really defies description. Extra fine. 30 cts.

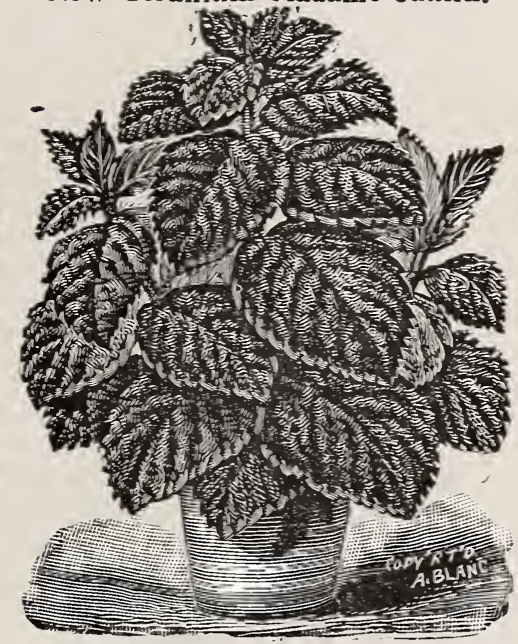

Gynura aurantiaca. (1) 107 -
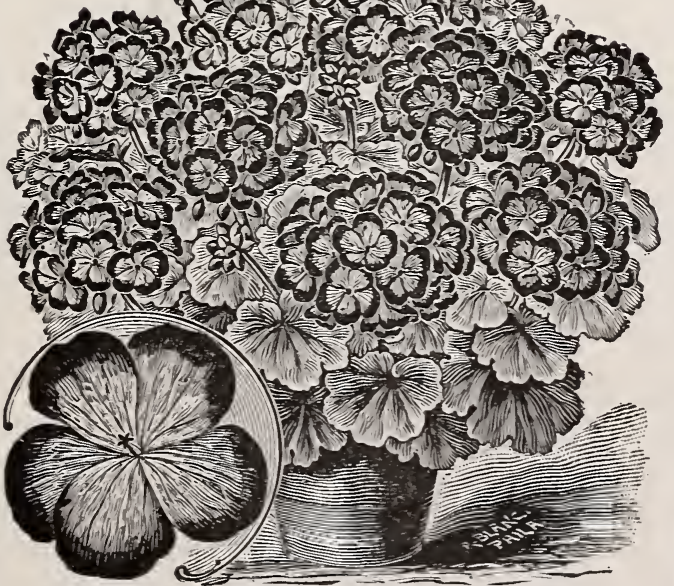

Pansy Geranium. Madame Bruant.

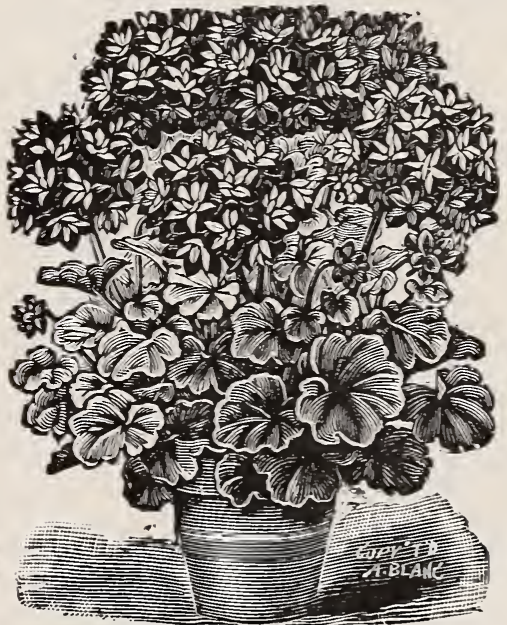

DOUBLE NEW LIFE GERANIUM.

A sensational novelty sent out at $\$ 2.50$ each!! A new departure in every was. The outer florets of a brilliant red; in the center of these floret, effecting a contrast difficult to realize. Plant dwarf and floriferous; always scarce. 15 cts.

GYNURA AURANTIACA

Purple Velvet Plant seems an appropriate name, the leares being alwars taken as artificial. Ther, and the stems are entirely corered with purple hairs. Shining, glistening, reflecting many new colors. Large yellow flowers. Extra fine. 20 cts. 


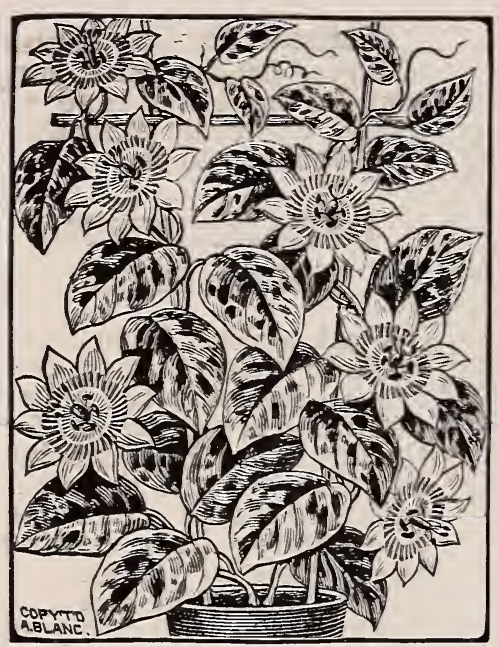

Variegated Passiflora.

PASSION FLOWER.

The hardy and early blooming Passion Flower bears a profusion of purple and white flowers of immense size and of most interesting and beautiful form. It will clothe a veranda with luxuriant foliage and bloom in the house. I5 cents.

The Variegated - Leaved Passion Vine.-Flowers nearly white; large, handsome. Leaves lively green, mottled and blotched with bright golden yellow. Elegant for indoors. 20 cents to $\$ I$.

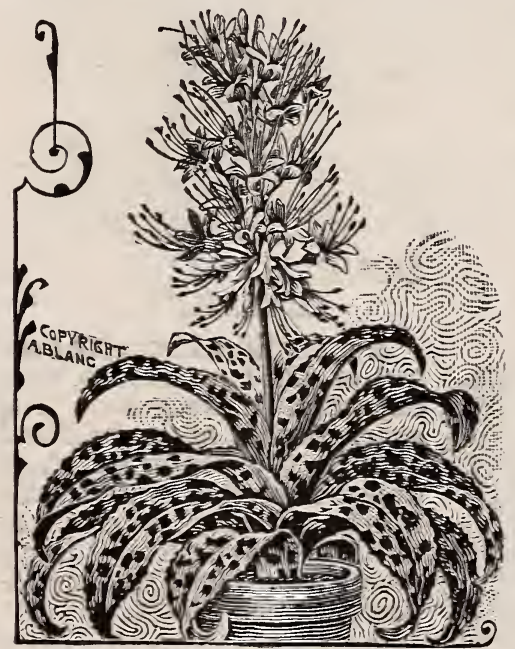

POLYANTHUS MACULATA.

Leaves dark green, mottled with chocolate brown spots. Fine form, like a century plant. Bears the first year a spike crowded with curious orchid-like flowers as fragrant as Tuberoses. A fine plant. 25 cents.

Send for our catalogue, and "Hints on Cacti," II6 pages, I80 cuts, Io cts.

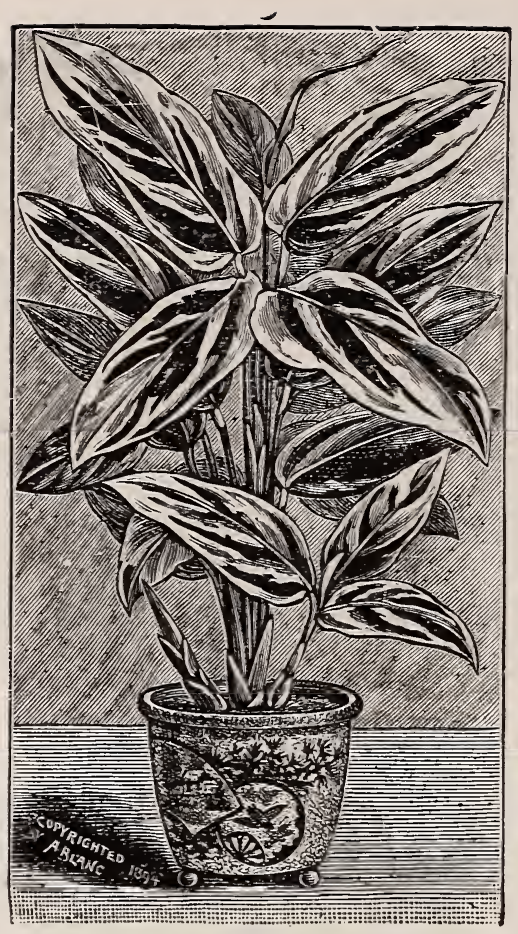

\section{PHRYNIUM VARIEGATUM.}

An immensely popular, high-class decorative plant, soon forming valuable specimens. Leaves bright green, striped with white and gray, sometimes pure white. 25 cents to \$I.

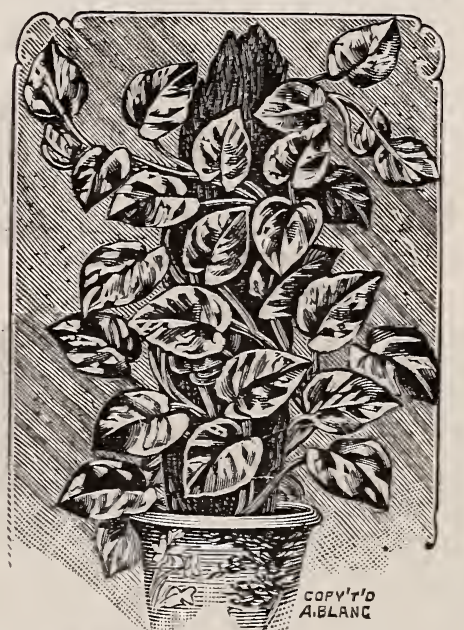

POTHOS AUREA.

A glorious sight when trained on a trellis or on the stump of a dead tree fern, covered with fresh moss. Thus, it looks like a globe of golden yellow leaves, streaked with light green. Rapid grower. Indoor. Branches cut off grow in water for weeks. Admired by all. Price, 25 cents to $\$ I$.

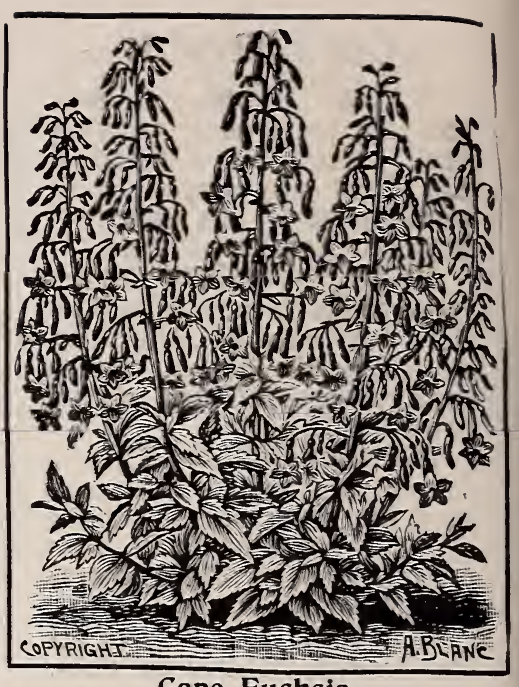

Cape Fuchsia.

\section{PHYGELIUS CAPENSIS.}

During our past dry summer this was never out of bloom, while geraniums alongside of it were perishing. When barely a few inches high bears from to to 20 bold, long spikes, completely crowded with showy, scarlet, drooping flowers, persistently produced from May until winter, and even then in the house. Perfectly hardy. 20 cents; seed, Io cents. The 7 Plants on this page for $\$ \mathbf{1} .20$.

"Gardening." 24 numbers for an order of $\$ 2.50$ and $\$ I$ additional.

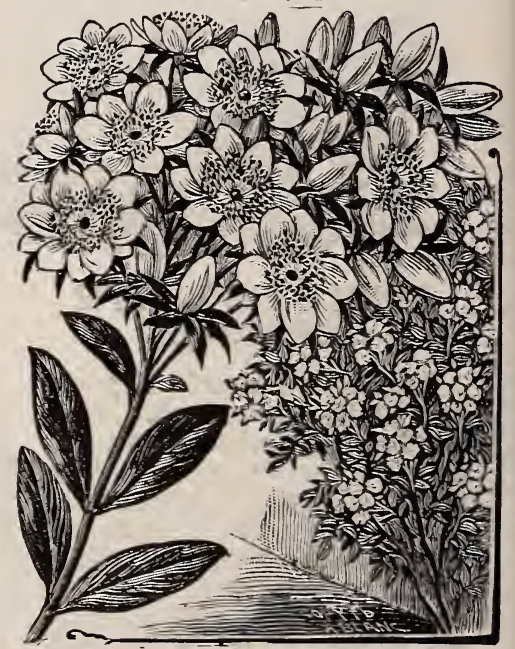

\section{PERESKIA ACULEATA.} The Lemon Vine.

In the fall will be covered with hundreds of dense clusters of semidouble, rose-like flowers, of almost overpowering fragrance, succeeded by edible fruit. Stems with buds will open their flowers in water. It is not hardy. Price, I5 cents to 50 cents, 


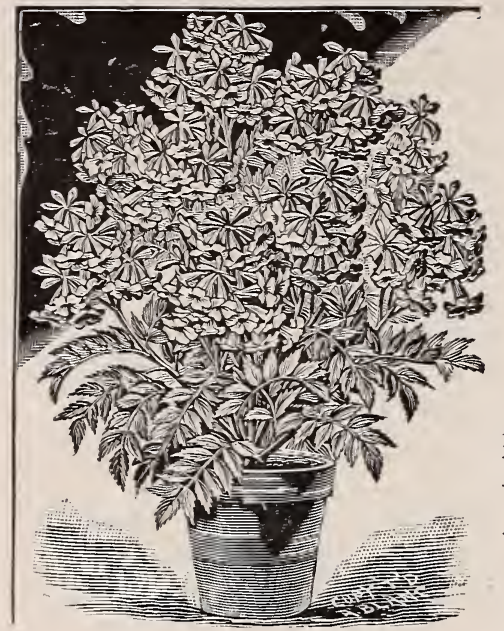

TECOMA SMITHII.

The new dwarf or bushy Trumpet Creeper is one of the sensational novelties of the season. It blooms nearly the whole year round. The flowers are over $z$ inches in length, of a rich lemon, shading to dark orange yellow. The nicely cut foliage furnishes decorative material for bouquets, etc. It is an excellent introduction. Highly ornamental. 25 cents to 50 cents; seed, Io cents.

\section{TRICYRTIS-Toadflower.}

A curious, new Japanese plant, which has proved perfectly hardy in this country. The flowers are somewhat lily-like in form and of a delicate pink shade, spotted with purple. 20 cents. Another sort bearing yellowish flowers spotted with black. Highly praised. 20 cents; both for 30 cents.

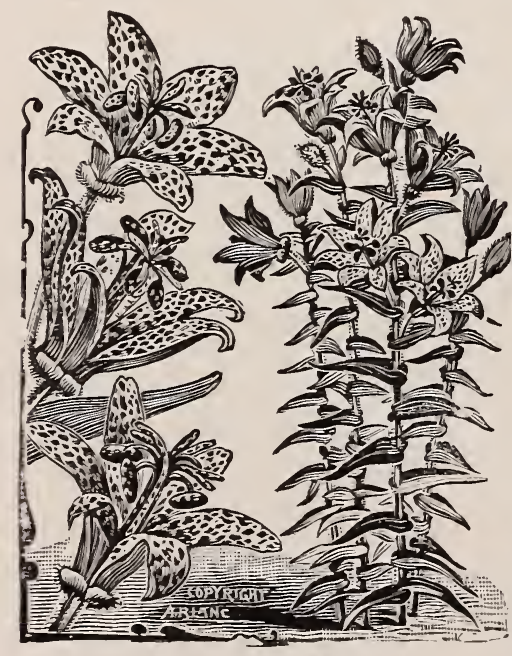

Tricyrtis-Toadflower.

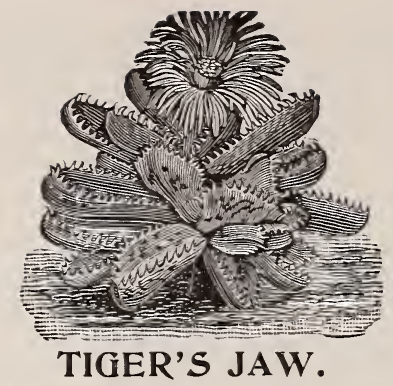

Mesembryanthemuin Tigrinum.

Is a very rare plant. Leaves thick, fleshy, edged with soft spines and resembling the open jaws of some animals. Very large and beautiful yellow flowers. A great curiosity. Price, 20 eents to $\$ I$.

Besides the above, we have 6 other Mesembryanthemums, all equallyinteresting and easy to grow. I $5 \mathrm{cts}$.; 4 for $50 \mathrm{cts}$.

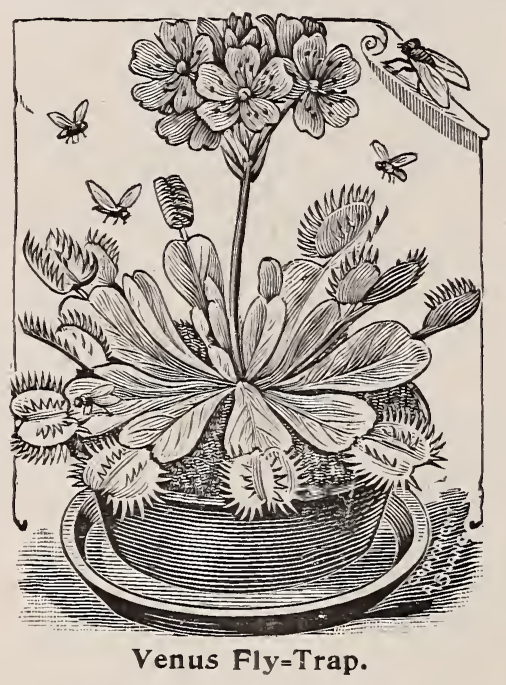

\section{TILLANDSIAS.}

Plants that cannot be praised enough for indoor growing. The leaves are very persistent, resisting sun, shade or dry air. They are of noble form, the flowers most gorgeous in coloring, and lasting frequently for months. T. Zebrina is a gem, with leaves of silvery gray, striped with brown. Most persons are positive that it is artificial. It lives for weeks without watering. Others have gorgeous leaves of wine color and green, and immense spikes of most brilliant flowers lasting for months, while those with plain green leaves have still handsomer flowers.

We recommend these Tillandsias and Bromelias to all lovers of fine plants, be $=$ ing confident that they will be highly appreciated. They are usually sold at $\$ I$ to $\$ 5$ each. Our price, 30 cents; 3 distinct sorts for 70 cents.

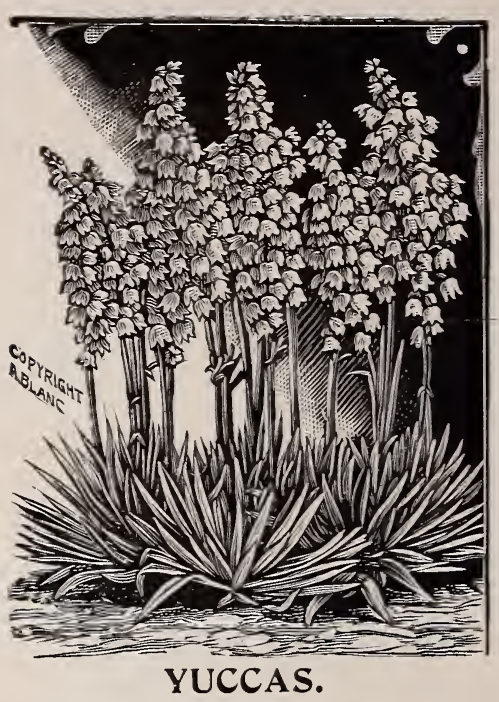

Plants which should be extensively grown. They are a most gorgeous sight when in bloom, the huge spikes of white flowers lasting for a very long time. Everyone having a garden should have them. We have a fine collection; among the best are Y. Aloefolia, Filamentosa, Gloriosa and Recurva. A plant that will please you. Price, 25 cents to $\$ 5$. For others, see "Hints on Cacti," price, Io cents,

\section{VENUS FLY=TRAP.}

One of the wonders of the ver ?table kingdom. The leaves are terminated by claw-like wings, armed with soft, irritable spines. Let a fly or any insect alight on them and they close upon them at once. Grows in moss. Price, 30 cents; 5 for \$I.

Night=Blooming Jessamine.-Very sweet-scented at night. Price, ${ }_{5} \mathrm{cts}$.

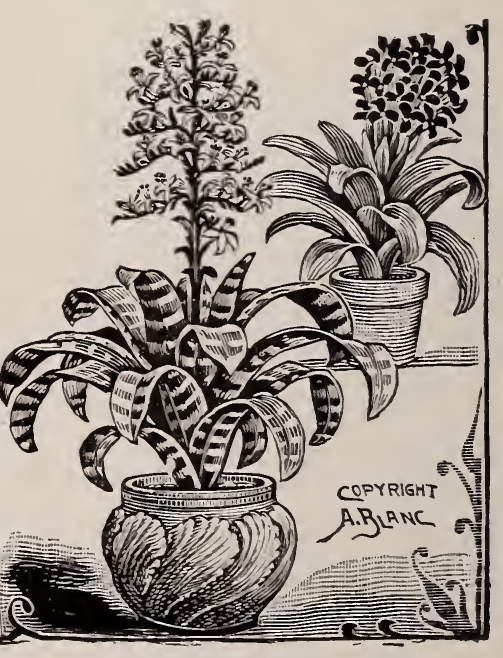

Tillandsias. 


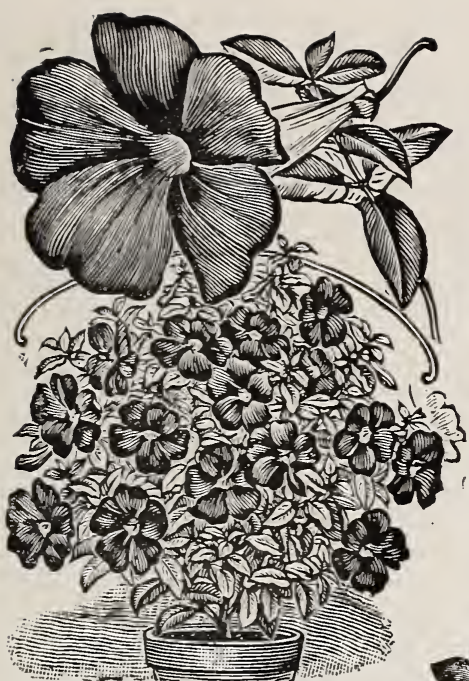

THUNBERGIA ERECTA.

A rare West African plant, with large flowers, with orange throad and yellow tube, very distinct in every way. Being of bushy growth, and an easy and constant bloomer, it should find favor with all who appreciate something new and pretty. Blooms also in winter and for a lifetime. 25c. THUNBERGIA FRAGRANS.

Sweet scented flowers are always welcome, and this is a beauty, the large flowers measure fully 2 inches across and are snow white, reliered wiih a golden dot in the center. Blooms when quite small, and almost incessantly. Dwarf climbing habit; native of India. $25 \mathrm{cts}$; the 2 for $40 \mathrm{c}$

Thunbergia Erecta.

\section{TECOMA STANS.} (Fire Bush).

"Yellow Elder" and "Fire Bush" have been suggested as names for this very handsome plant. It blooms readily in 3 -inch pots, the bunches of yellow and fire-scarlet flowers being exceedingly conspicuous and attractive. If allowed to run it will attain considerable height. Fine plants, 20 cts.

\section{$\star$ TECOMA AUSTRALIS.}

(New). The famous Wonga Wonga Vine of Australia. A grand half-hardy climber, now first offered. Its handsomely cut leaves soon cover any surface, and are profusely studded with large panicles of creamy white trumpet-shaped flowers, tinged inside with purple and red. Fine plants, 30 cts.
000

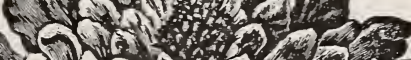

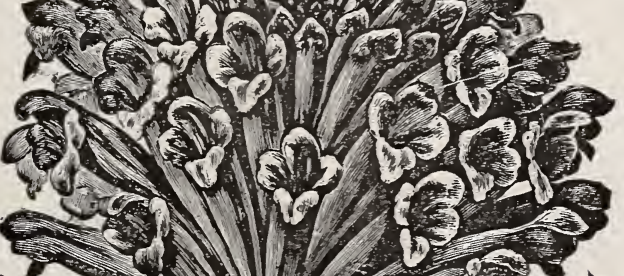

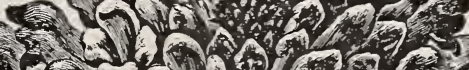
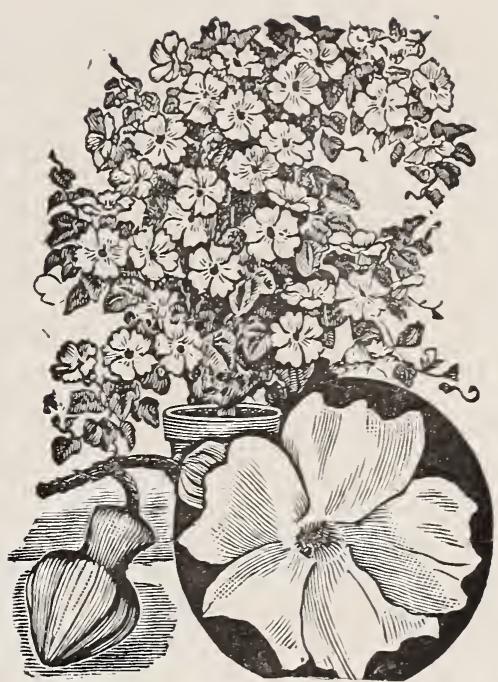

Thunbergia Fragrans.

\section{TECOMA CAPENSIS}

This rare plant is a native of the Cape of Good Hope. The highly ornament foliage is surmounted by erect clusters of orange-scarlet flowers. Fine for low trellisses or as a pot plant. $20 \mathrm{c}$.

\section{$\star$ THLADIANTHA. Golden Creeper.}

A handsome new tuberous vine from China, bearing very large pure, yellow cup-shaped flowers, succeeded by large, bright, red fruits. When these appear together on the plant the effect is most.bewitching and appreciated. Being perfectly hardy, it should be used for terraces, railings, arbors or fences, being too strong a grower as a pot plant, strong plants or tubers. $25 \mathrm{c}$.

TECOMA MACKENNII bears racemes 1 to 2 feet in length of showy, rosy lilac, trumpetshaped flowers. Extra fine. 30 cts.

Do not forget to order our great May surprise collection. Price $\$ 1$.

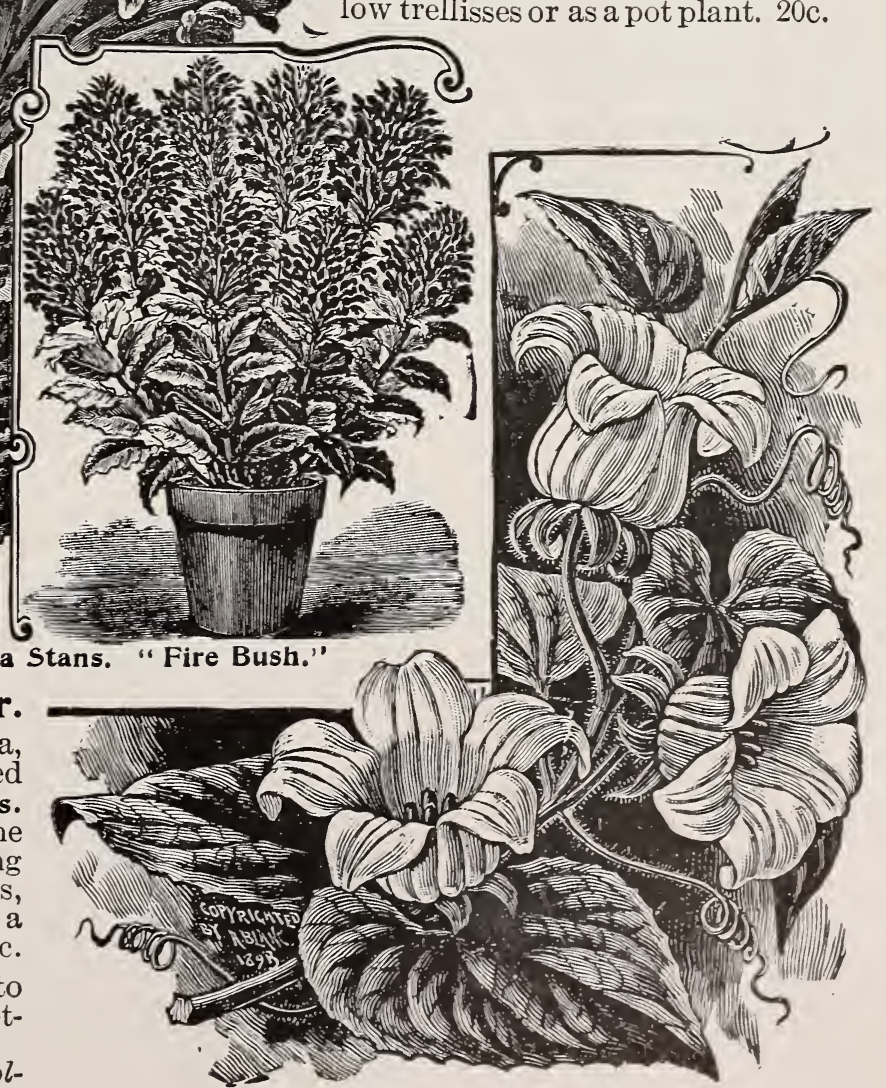

Thladiantha. Golden Vine. 


\section{NEW AND RARE BULBS AND TUBERS.}

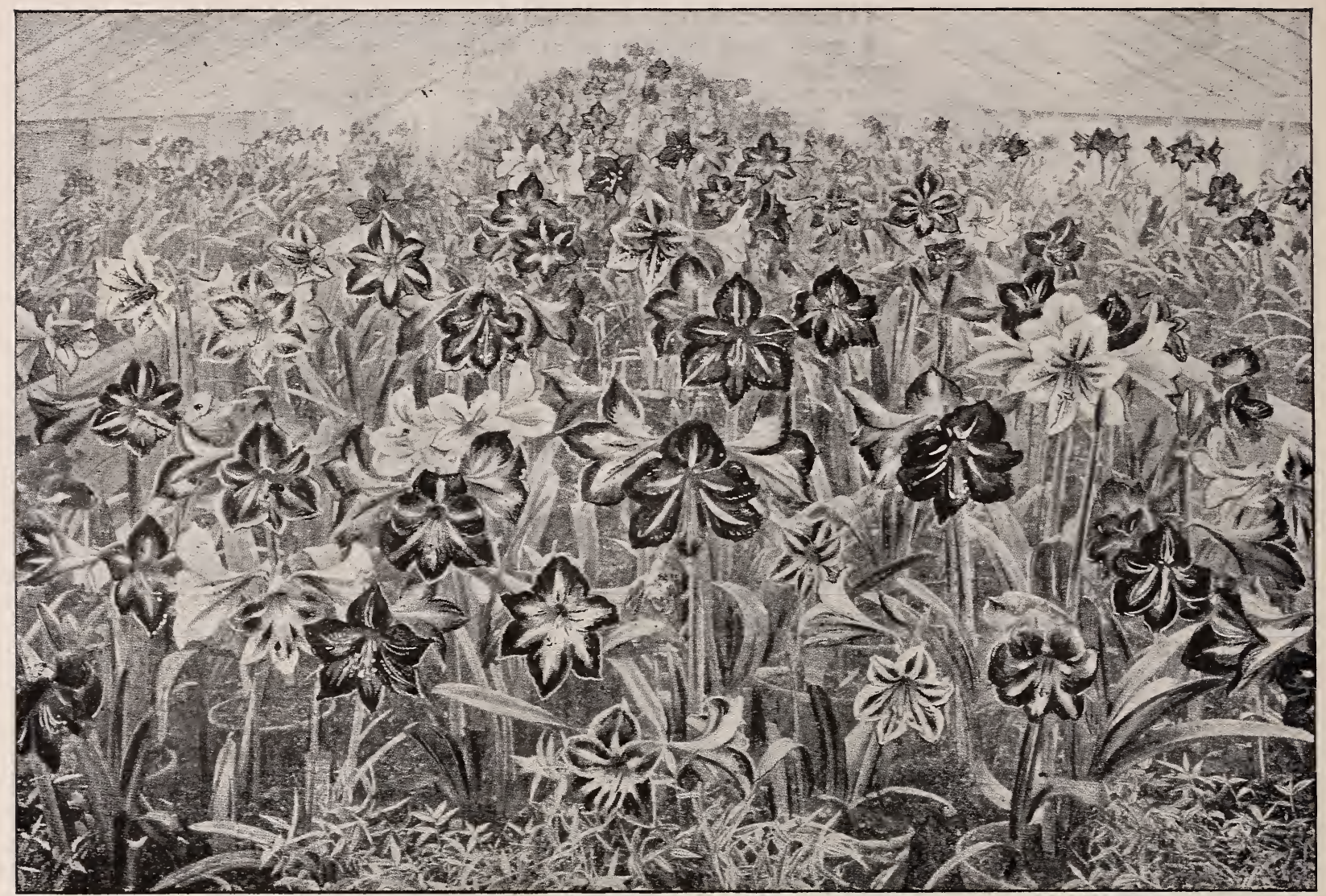

\section{AMARYLLIS. (Queen Lilies.)}

It would be difficult to find a flower more gorgeous in color and effect than the Amaryllisses. A glance at the picture shown above is sufficient to prove it. Besides their easy management and free blooming there is a richness about them that commands admiration. We refer especially to the strain originated by the Messrs. Veitch \& Sons, of England, of which we have perhaps the largest stock in the country. They are sold in Philadelphia by prominent florists at $\$ 3$ to $\$ 10$ each, when in bloom, while in England $\$ 10$ to $\$ 25$ per bulb is not an uncommon price. These flowers often measure 10 inches across and each bulb produces 8 to 10 flowers. Besides the list named below we have several hundred grand varieties of which we have only one or two bulbs in stock. All grand flowers that cannot be duplicated at any price. Our price for these is $\$ 1$ each, $\$ 10$ for 12 . The same strains that have not bloomed 30 to 50c. Send for list of other sorts.

Arethuse-Immense flowers, white, banded with rose and carmine. Entirely unique and beautiful. \$1. Aulica-Rich, deep crimson, with large green star in center. Broad petals, very large. Extra fine. \$1.50. Aurea-(Lycoris Aurea)-Japanese species, with narrow petalled golden flowers, borne in clusters. 35c. Belladonna-From Cape of Good Hope. Pure rose flowers in dense clusters, nearly hardy; large bulbs. 25c. Brilliante-Immense flowers nine inches across. Gorgeous amaranth red, witd white centre, frequently bears twelve flowers at one time. One of our finest and most beautiful. Only 2 bulbs. $\$ 2.50$ each. Creole-Tery dark velvety red, with white stripe and feathering. Extra fine and very pretty. \$1.50. Consuelo-Grand flower. Creamy white, beautifully feathered with crimson and rose. Extra good. \$1.50. Cleopatra-Dark purplish red. Fine flowers and very free bloomer. Every garden should have one. 75c. Etoile du Nord-Northern Star. Flower almost pure white, striped and spotted pink. Very nice. \$1.50. Equestre-A very free bloomer, quite common now. Flowers orange red, with white center. Extra. 20c. Formosissima-Intense dark red velvety flowers. Well-known Mexican species. Very beautiful. 15c. Masterpiece-Gigantic flowers, showing various shades of crimson, carmine, maroon and white. Fine shape and very distinct from all others. Every flower lover should have these pretty Amaryllis. \$2.50. Othello-Very dark velvety red, almost maroon. Grand contrast with others. Extra good sort. 75c. Sappho-Beautiful cherry red, shading to rose. Grand rounded petals. Extra fine. Only 2 bulbs. \$2.50. Vittata-Flowers white, delicately pencilled with red, pink or carmine. They are very pretty. 40c.

All the above bulbs have bloomed for us. We have smaller bulbs, raised from seed of the above, at from $\mathbf{1 5 c}$. to 50c., according to size. Seed saved from the above grand strain $\mathbf{1 5 c}$. per packet. 


\section{New American Hybrid Cannas GRAND NEW COLORS, ORRIO- New American Hybrid Cannas}

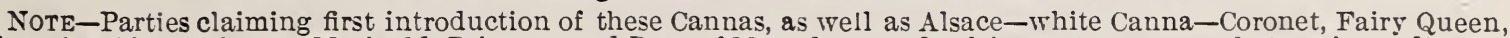

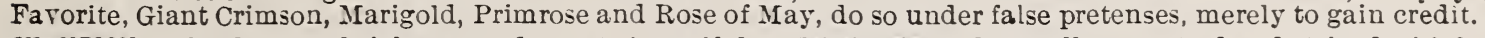

CHAMPION.-The largest, brightest and most beautiful Canna in existence to date. Immense spikes of gigantic flowers with petals $2 \frac{1}{2}$ inches wide, of a pure, dazzling crimson-scarlet, overlaid with a golden luster and purplish reflections. All experts who have seen this pronounce it the finest Canna in existence. Were $\$ 5$, now $50 \mathrm{c}$. DUCHESS OF MARLBOROUGH. - Absolutely pure pink. Numerous spikes, with three to four trusses of flowers, each bearing from 50 to 70 flowers. Flowers 5 in. 20c. DUKE OF MARLBOROUGH.-The darkest of all Cannas; extremely rich crimson-maroon, shading towards purple and black; extremely floriferous. $20 \mathrm{c}$.

KLONDIKE.-A pure, gilded orange. Absolutely without a rival. A color quite essential and much sought for for bedding. Flowers enormous; petals well rounded. Trusses compact, 1 foot across. 25c.

MAIDEN'S BLUSH. - Foliage massive and leathery. Large spikes, with flowers of good size. This color is quite new. and might be called a rosy flesh. $25 \mathrm{c}$.

TOPAZ.-The first pure yellow-flowered Canna of large size. It is ideal in form, very substantial and produces large and open trusses. A grand Canna for effect. 50c.

BRILLIANT.-Three upper petals bright yellow; middle and lower petals bright, flaming red. Flowers 50 to 60 to a spike. Beautiful and unique. 20c.

CUBA.-Enormous spikes of immense flowers. The segments are deep chrome-yellow, half covered by a large blotch of deep vermilion red, and entirely distinct in the shades of its coloring. $25 \mathrm{c}$.

LORRAINE. - A charming combination of colors: Howers large, a bright pink, spotted red; petals broadly and clearly edged with pale yellow, soon changing to creamy white. Spikes bearing 40 to 50 flowers. $20 \mathrm{c}$.

TRIUMPH.-Velvety scarlet, overlaid with deep maroon spots ; flowers of very large size, very substantial. Vigorous grower and constant bloomer. $20 \mathrm{c}$.

VICTORIA. - Immense trusses of large flowers on bold, heary stalks. The three upper segments pale lemon-yellow, feathered, in center only, with rose spots on pink ground. Lower petal rich yellow, with distinct, bold design of velvety amaranth-red. $50 \mathrm{c}$.

NEW CANNA "PHILADELPHIA." Originated and Introduced by Us in 1896.

After years' trial this has proved to be one of the best Cannas up to the present time. It is of uniform growth, about $3 \frac{1}{2}$ feet, blooming evenly and continually during the entire season, bearing large spikes densely crowded with bright glowing crimson-scarlet flowers; rich and velvety. Their velvety texture resists rain and storms with great impunith. Foliage bright green, healthy and rigorous. 20c. One of each of these 12 grand Cannas for $\$ 3.25$.

ALSACE.-

This is the nearest approach to a white Canna. Extremely vigorous.
DEFENDER.-Clear yellow, spotted and striped with bright scarlet. Large, fine heads.

GLORIOSA.-One of the dwarfest Cannas in cultivation. Blooms when only 6 inches nigh. Bright amaranth red, each petal edged with clear yellow.

GOLDEN STAR. - The flowers a re elegantly fringed, and of a rich golden yellow with scarcely a spot.

They are produced in massive trusses and borne in rapid succession, even when the plants are scarcely 10 inches high. It is the dwarfest of all yellow Cannas.

JOHN WHITE.-New rariegated-ieaved Canna. Foliage penciled green and yellow, sometimes with pink, and edged with red. Very beautiful as a pot plant.

MARIGOLD. - A very rich orange, with less scarlet or salmon than any so-called orange.

PRESIDENT CLEVELAND.-Also a grand new sort, with orange-scarlet flowers. Grand for bedding.

ROSEMAWR. - The most showy and handsomest of all pink Canna, bearing enormous well-rounded flowers of a salmon-rose color. Is an exceeding free winter bloomer. SUNRAY.-Rich, bright yellow, with stripes and dashes of

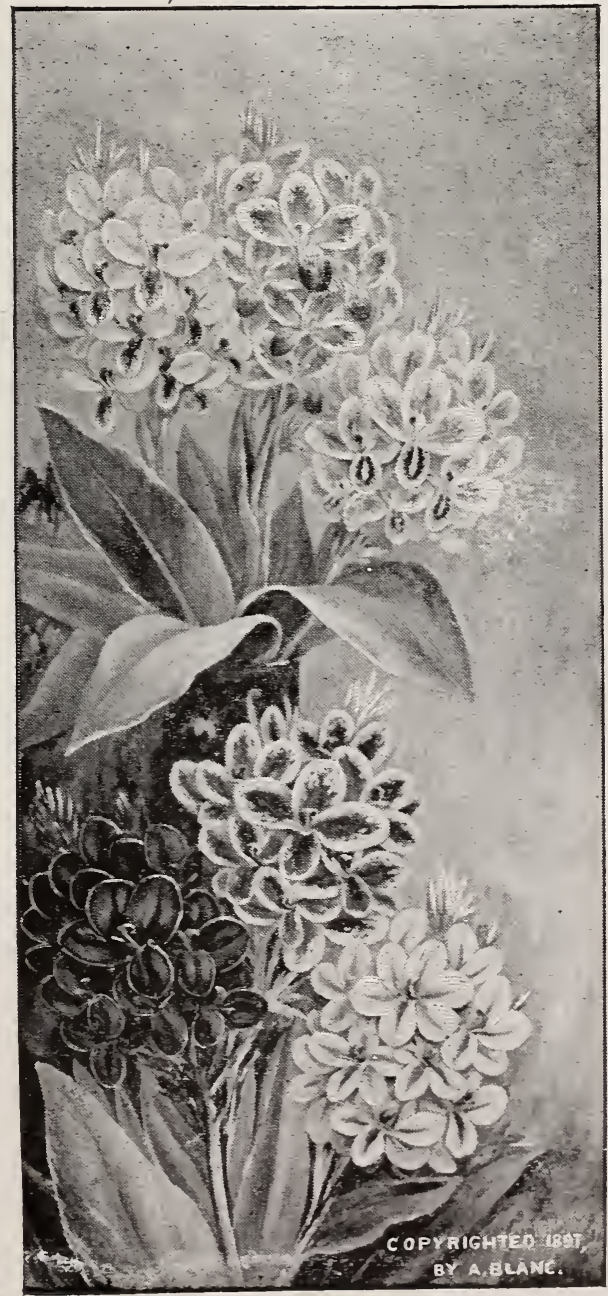

New American Cannas. fiery scarlet running almost to edge of petals. Distinct.

All the above $15 \mathrm{c}$. each. ROSEMAWR 25c.

NEW AMERICAN CANNAS FOR 1900.

Alberta.-Bright, flashing crimson flowers, shading deeper towards edges; broadly bordered, mottled yellow. 25c.

Abraham Lincoln.-Enormous growers, flowers large and fully expanded, thick velvety petals, fiery crimson. $25 \mathrm{c}$

Annie Laurie.-Dainty sort. Exquisite spikes of gladiolus-like flowers, silvery rose with white throat. $25 \mathrm{c}$. Baltimore.-Rich bright cherry red, with golden yellow throat. Very vigorous grower, free bloomer. 20c. Black Prince.-Darker and richer color than our Duke of Marlboro. Velvety maroon, almost black. $25 \mathrm{c}$. Buttercup. - L a rge, handsomely formed flowers, of a rich buttercup yellow. Extra good sort. 30c. George Washington.-Noble variety; superb form and color; flowers are deep velvety crimson and borne in bold erect massive trusses. $50 \mathrm{c}$. Luray.-Bright shining rose, deepening as flower expands to rich cherry red. Large full heads. 30c. Lighthouse.-Elegant shaped flowers, with broad petals; color clear lemon-rellow, spotted red; heads often measure a foot across. We refused $\$ 50$ for our first plant. $50 \mathrm{c}$. Starljght.-Very pale lemon-yellow fading to creamy white. Larger clusters than our Alsace. 30c.

Martha Washington.-One of the very best, if not the best, rose canna in existence. The trusses are large and full; plant dwarf. 40c. Virginia.-A nother grand and strikingly beautiful sort, with bright rose-pink flowers. 25 c.

We offer 10 Cannas, our choice, all named sorts, for $\$ 1$, 5 for $50 \mathrm{c}$, or 15 unnamed for $\$ 1$, 7 for 50c.. a! I postpaid. 


\section{NOVELTIES IN DAHLIAS.}

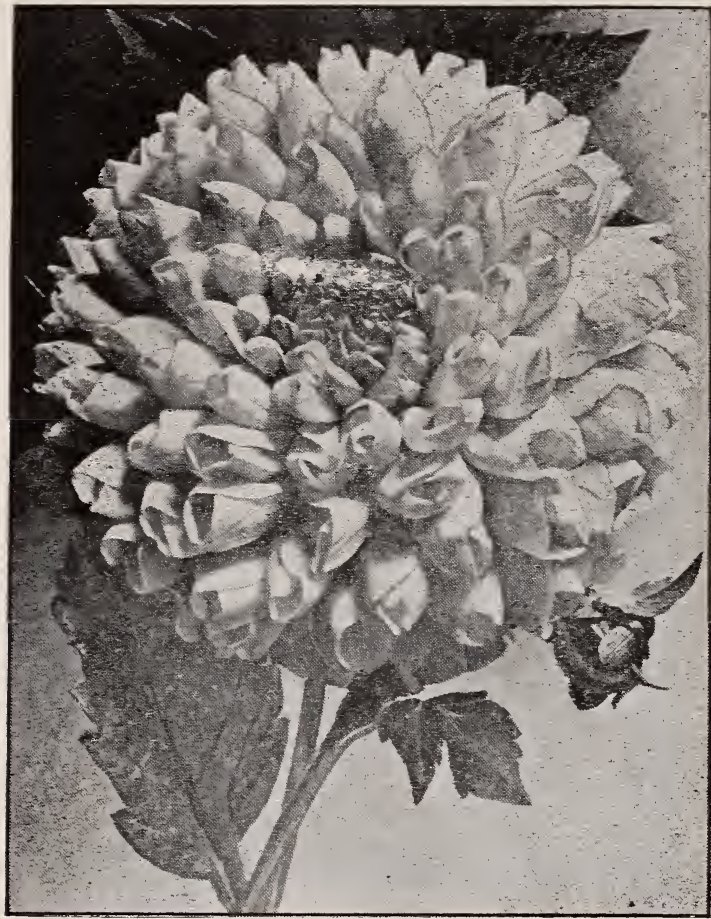

Grand Duke Alexis.

The Most Beautiful Dahlia, "GRAND DUKE ALEXIS." Won first prize as best novelty in 1897 . This is now considered the grandest Dahlia in cultivation. Whenever oivinis it attracts great crowds. It al ways wins first prizes, because there is no other Dahlia like it. Flowers measure 20 inches around. The color is a rich ivory-white, tipped with pink, especially towards the center. Petals peculiarly quilled. Most exquisite new type. 25c.; plants 13 c. Our Grand New Show Dahlia, "GILT EDGE."-Won first prize as the best new Dahlia. The petals are recurved like a chrysanthemum; the color is i vory-white, deeply edged with rich golden yellow; entirely unique and most beautiful. 25c., plants $15 \mathrm{c}$.

The Giant of Dahlias, "CoLossus."-First prize as largest Dahlia. Flowers measuring 20 to 24 inches around, perfect in form; a clear, deep wine color; long stems, good for cutting. $25 \mathrm{c}$., plants $20 \mathrm{c}$.

New Cactus Dahlia, "LILACINA." - A new English rariety. A pure delicate lzlac is a new feature which will be appreeiated. Excellent for cutting. Roots 35c., plants 10c. New Dahlia, PERLE de la TETE d'OR.-Pearl of the Park of the Golden Head is a grand new French Dahlia, entirely distinct in form from any other. The color is white, faintly shaded to lilac. The form is more like a Chrysanthemum. We were awarded a first prize when we first exhibited it. $25 \mathrm{c}$., plants $15 \mathrm{c}$.

New Cactus Dahlia, HOHENZOLLERN.-Voted second best in Germany. Grand cactus form. The color is a fine old gold, glistening as if gilded. Plants only $30 \mathrm{c}$.

New Miniature Cactus Dahlia, AURORA.-New English sort which has been awarded certificates wherever exhibited. It grows into a nice dwarf bush $2 \frac{1}{2}$ to 3 feet high. The flowers are small, very freely produced. As many as 50 to 75 flowers can be cut at one time. They are elegant for cutting. The color is a lovely shade of salmon orange with a sheen orlustre of bluish tint; petals are twisted, showing a reverse of old rose. 50c.; plants only.
New Dahlia, HENRY F. MICHEL.-A colossal Dahlia often measuring 8 inches across. Good cactus form. A combination of golden yellow, orange ana red. 广Iost glorious. $25 \mathrm{c}$, plants $15 \mathrm{c}$.

Grand New Ccatus Dahlia, "LORELEY."-Was roted in Germany as the best Cactus Dahlia in existence. The color is a bright pink, with white centre: petals beautifully twisted and incurved; excellent form and exceedingly free bloomer. Roots 50c., plants 30c.

Finest Now Show Dahlia, "STORM KING."-This is absolutely the best white show Dahlia even grown in this country Its form is perfection; the flowers are white, beautifully quilled and carried on long erect stems. It is the most profuse bloomer of all Dahlias as well as the earliest; the d warfest for such a free grower. As many as 60 open flowers have been counted on one plant. Roots $50 \mathrm{c}$., plants $25 \mathrm{c}$.

\section{OF THE BEST CACTUS DAHLIAS.}

\author{
Note-F. C. C. means First-class Certificates.
}

Gloriosa.-We put this at the head of the list as one of the best of the Cactus Dahlias. Its grand form, immt... size, and brilliant crimson color have not been approached by any other. $25 \mathrm{c}$., plants $15 \mathrm{c}$.

Baron Schrœder.-Imperial purple, grand color, large size. Beauty of Brentwood.-Purple magenta ; extra.

Bertha Mawley.-Like a chrysanthemum; florets long and tapering; a rich cochineal, shaded viotet. 2 F. C. C. Black Prince.-Intense velvety maroon; large and fine. Blanche Keith.-Pure yellow; petals long and twisted, full and even; true Cactus; free bloomer. $3 \mathrm{~F}$. C. C. Bronze Cactus.-Buff, yellow and bronze ; unique. Countess of Gosford.-Of singular appearance. Color a rich cinnamon, shaded toward gold. $3 \mathrm{~F}$. C. C.

Countess of Radnor.-A combination of delicate shades of orange, bronze yellow and intermediate shades. 3 F.C. C. Delicate.-The pink water lily Dahlia. One of the most popular at English shows. Quite distinct. 4 F. C. C. John Bragg. - Very dark maroon ; fine form.

H. Cannell.-Rich velvety crimson; extra fine.

Kaiserin.-Flowers large, rich sulphur yellow, outer florets tinged lemon. Highly praised. 3 F. C. C.

King of Cactus. -Immense dazzling scarlet.

Kynereith.-Brightest of all vermilions.

Lancelot.-A peculiar shade of striking reddish salmon; rich and effective; one of the very best. $3 \mathrm{~F}$. C. C.

Matchless.-Has been awarded 18 first-class certificates. Intense velvety-maroon; 6 to $7 \mathrm{in}$. across Free bloomer. Maid of Kent.-Ground color rich crimson, overlaid with intense cherry red; tips of petals pure white.

Mrs. Peart. - The first real white Cactus Dahlia ever raised. Petals beautifully quilled, borne on long stems. Professor Baldwin.-Deep orange-scarlet ; fine.

Wл. Pierce.-Exquisite and pure golden yellow. Extra. Violet Morgan.-Base of florets cream or fawn, shaded toward edge with delicate pink; extra fine sort. Zulu.-Darkest maroon, really almost black.

Price of the above Dahlias, 20 cents each for roots, 6 for $\$ 1$; plants, 15 cents, 4 for 50 cents, 9 plants for $\$ 1$. After May 1 we can only supply plants.

\section{NEW DECORATIVE DAHLIAS.}

Clifford W. Bruton.-Finest yellow decorative Dahlia. Exceedingly free bloomer ; flowers large and full.

Wm. Agnew.-Grand; more than 7 inches across; rich shade of dazzling red. One of the best for cut flowers. Red and Black.-A gorgeous combination. Petals rich velvety red, edged with bla:ck ; flowers large, well formed.

Roots 20 cents. One plant of each for 45 cents. 
I5 SELECTED DECORATIVE DAHLIAS.

Annie Harvey.-Very rich crimson; grand Constancy.-Orange, shaded bronze, tipped white.

Countess of Pembroke.-Extra-fine lilac. Electric.-Dazzling red; very profuse. Empress of India.-Deep crimson-black Henry Patrick.-Best white; extra fine. Lady Montague.-Rich salmon, striped white.

Miss Barry.-Beautiful imperial purple. Mrs. A. Newell.-Mahogany red; beautiful. Mrs. Geo. Reed.-White, edged rosy lake. Nymphea.-Pink and white; floriferous. Oriental.-Pale salmon; fine form.

Oban.-Silvery fawn; one of the very largest. Rayon d'Or.-Bright orange, banded white. Wiltshire Lass. - French white; long stems.

\section{SELECTION OF BEST LARGE SHOW AND FANCY DAHLIAS.}

A. D. Livoni.-Soft pink; quilled petals. Arabella.-Primrose, tipped lavender. Bird of Passage. - White, tipped pink. Burgundy.-Rich, dark puce; very fine form. Colibri.-Deep scarlet; good bedder.

Earl of Ravensworth.-Lilac; grand sort. Eclipse.-Bright orange-scarlet; fine form. Ethe1 Britton.-Blush white, edged purple. Elegans.-Rosy purple, striped white; fine. Fern Leaf Beauty. - White, margined crimson. Flag of Truce. - White, tipped purple; large. George Smith.-Bright magenta; splendid, James Vick.-Intense purple maroon; dwarf. James Stephens.-Bright orange-scarlet. James Cocker.-Large, purple; fine form. John Walker.-White; large flower. John Standish.-Bright red; constant. Keystone.-Pink, striped crimson; fine. Lemon Giant.-Very large; golden yellow. Lucy Fawcett.-Pale straw; pencilled rose. Marguerite.-Very beautiful lilac; pretty color Miss Browning.-Yellow, tipped white : grand Miss Florence Shearer.-New; clear lilac. Miss May Iomas.-New; white, suffused rose. Miss Thatcher.-Rich pale yellow; free. Miss Cannell.-White, tipped rose; extra. Mrs. Gladstone.-First prize; soft blush.

Mrs. Langtry.-Cream color, tipped carmine. $01 \mathrm{~m}$ Pere.-Deep" saffron; quilled; dwarf.

Paul's Scarlet.-Extra bright Penelope. - White, flaked lavender; prize-taker. Pluton.-The finest of all the yellows.

President.-White, shaded lavender; fine sort. Royal Queen.-Creamy ground; edged purple. Ruby Queen.-Clear ruby-red; shaded.

S. Sickman.-Beautiful peach color.

Snow.-Pure white; extra fine; good form.

Solfaterre.-Bright sulphur-yellow; rich color.

Souvenir de Mme. Moreau.-Deep red-pink.

Sunbeam,-Pinkish white, tipped pnrple.

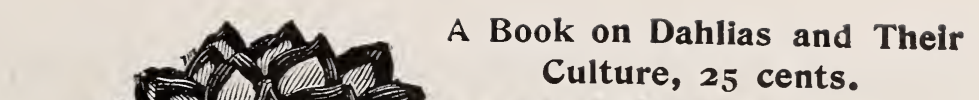
Culture, 25 cents.

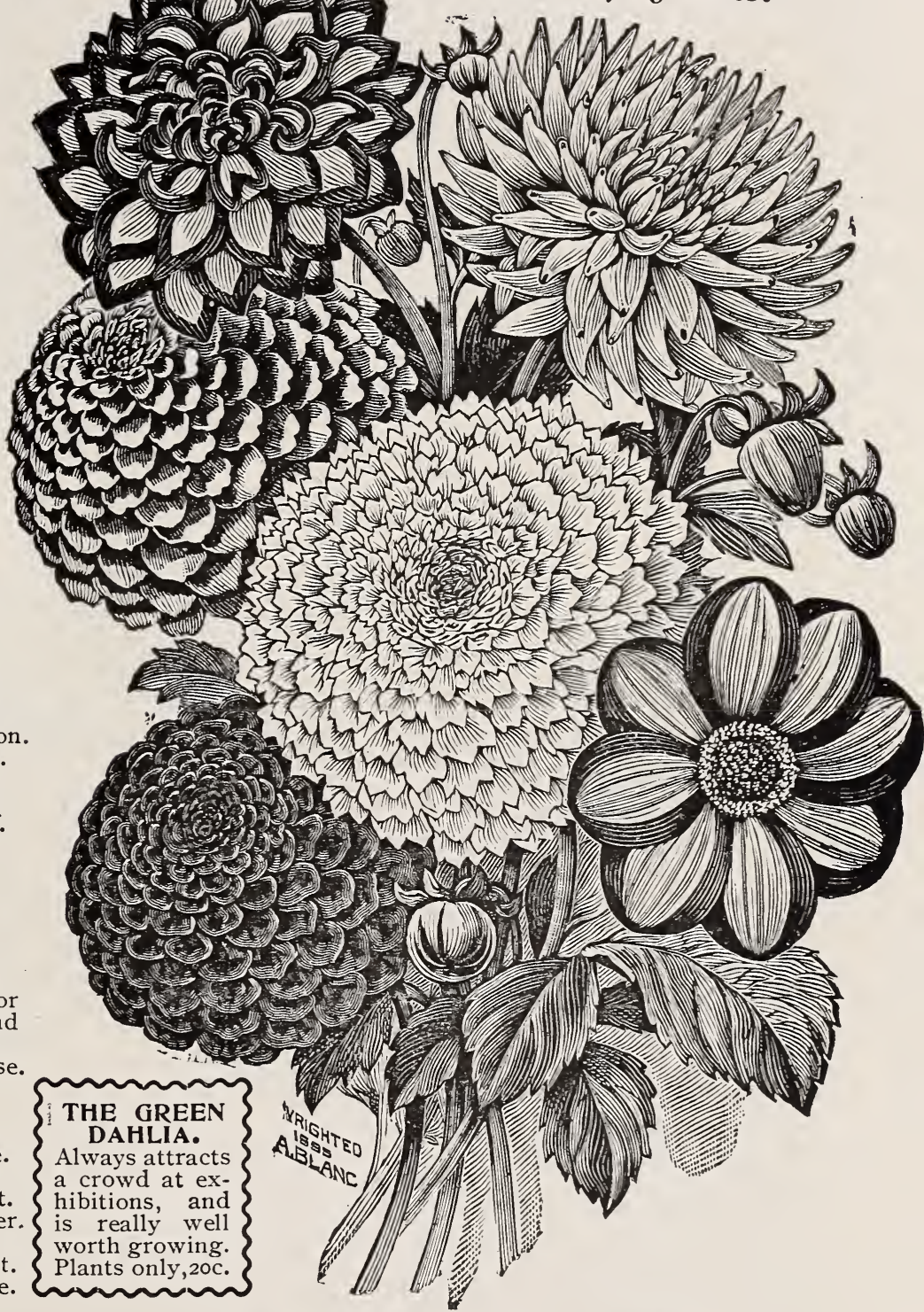

Triomphe de Solferino.-Red; immense size. Village Maid.-New; primrose, shaded red.

Willie Garratt.-Bright cardinal; good form.

Wacht am Rhein.-Peculiar shade of lilac.

\section{EXTRA-FINE BOUQUET DAHLIAS.}

F. T. Jungker.-Finest shade of golden amber

Dr. Webb. - Very dark crimson; effective.

Guiding Star.-Quilled petals, pure white.

Kleine Domatia.-Salmon-buff; excellent.

Little Jack.-Rich crimson-maroon.

Little Frank.-Light amber, shaded salmon.

Little Prince.-Red, tipped white; earliest.

Price, of all Dahlias on this page: Roots, 20 cents each, 3 for 50 cents, 6 for $\$ 1,12$ for $\$ 1.75$; plants, after May, I5 cents each, 4 for 50 cents, 9 for $\$ 1,20$ for $\$ 2$.

Dahlias without names: Roots, I5c. ea., 4 for $50 c$., 9 for $\$ 1,20$ for $\$ 2$; plants, I2c. ea., 5 for $50 c$., I2 for $\$ I$. Plants will in all cases bloom earlier and even more profusely than roots.
Little Valentine.-Bright purple-maroon.

Loveliness.-White, tipped pink and purple.

Marguerite Bruant.-Pure white; extra good.

Sunshine.-Brilliant scarlet-orange.

Scarlet Gem.-Exquisite shade of scarlet.

Vivid.-Bright crimson-scarlet; first prize.

Sappho.-Dark maroon, tipped blush. 


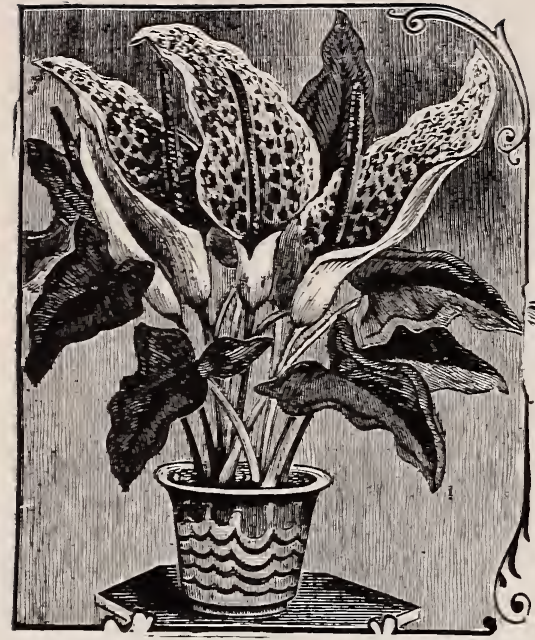

$\star$ THE LEOPARD CALLA.

This is the true Arum Dioscoride decribed by Dioscorides and recently rediscovered in Asia Minor. The flower often measure $15 \mathrm{in}$. in length. The color is yellow and green, spotted with dark purple; a most extraordinary flower indeed, as easily grown and bloomed as any Calla. Very scarce. 50c. each.

CALLA HASTATA-The old "Yellow Calla," which scarcely deserves the title since the "Golden Callas" have appeared. However, pretty and easily grown. 25c. and 50c.

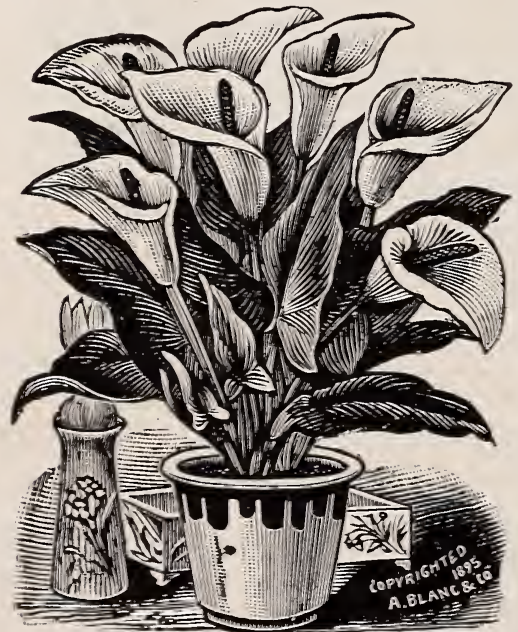

THE FRAGRANT CALLA.

One of $Y$ r Burbant's wonderf creations, the original price of which $\$ 1,500$ ! Unusually dwarf, early and prolific bloomer, small bulbs, blooming freely the whole summer and autumn, flowers large, pure white, fragrance of violets and lilies. Direct from Mr. Burbank. 25c. and 50c.
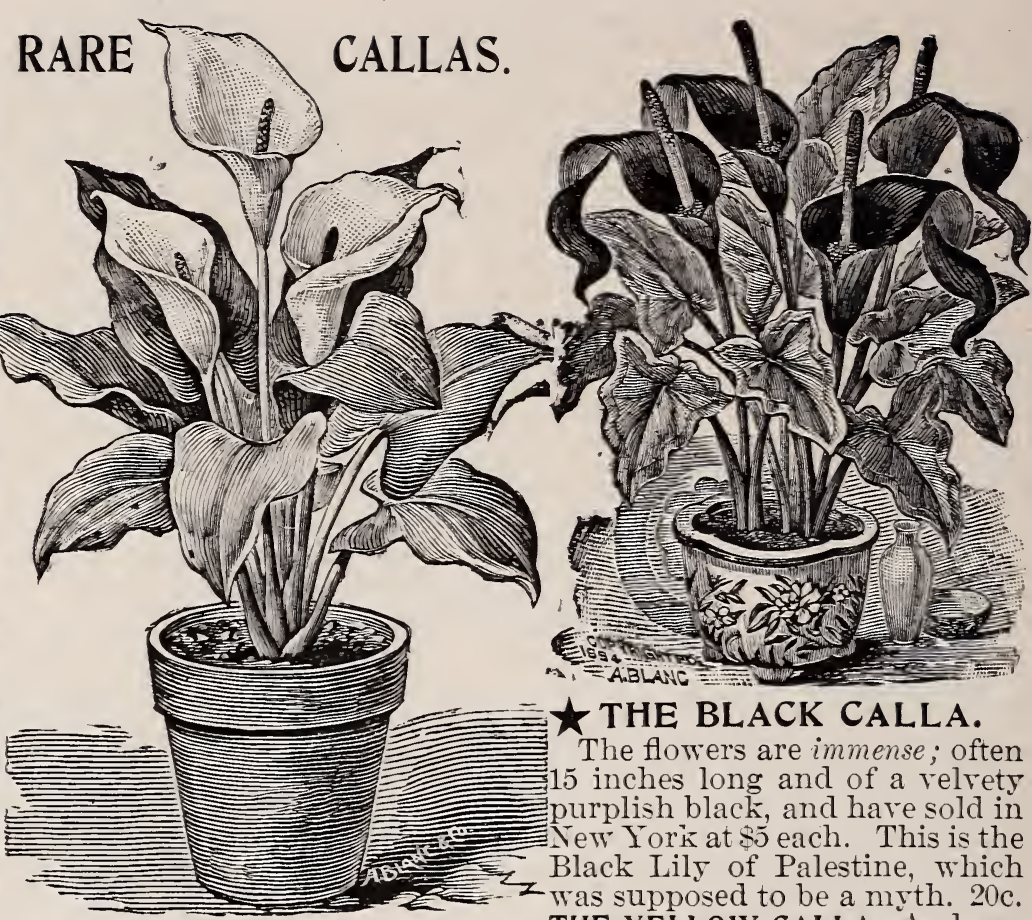

The flowers are immense; often 15 inches long and of a velrety purplish black, and have sold in New York at $\$ 5$ each. This is the Black Lily of Palestine, which THE YELLOW CALLA$\downarrow$ THE GOLDEN CALLA. as the Lily of the Nile; sulphur yelR. Elliotiana. First offered by low, with purple throat; nearly us in 1893 at $\$ 10$ per plant, is now equal to the Golden Lily. 30c. more plentiful, but not common by CALLA $A$ ETHIOPICA - The old any means. The flowers are bright Lily of the Nile. $15 \mathrm{c}$. butter yellow, grand in every re-
spect and a valuable treasure. $75 \mathrm{c}$. to $\$ 3$ each, according to size.

$\$ 500$ were refused some years ago for three plants like this Calla.

t CALla REHMANNI-Usually sold as the "Pink Calla." Bulbs received direct from the Transvaal only show a faint pink edge. Thes are, however, very beautiful, thick and waxlike. Very rare $\$ 1.50$.

† Calla devoniensis-An English sort, praised on account of free blooming and snow whitness. $50 \mathrm{c}$. ‡ THE GODFREY CALLA-Tery prolific and dwarf. Pure white. $50 \mathrm{c}$ $\uparrow$ CALLA NELSONI-One of the new yellow sort. $50 \mathrm{c}$.

THE SPOTTED CALLA-A neglected beauty which should find a place in every window for its beautiful leares. Grow it by the dozen. $10 \mathrm{c}$, 3 for $25 \mathrm{c}$., 15 for $\$ 1$.

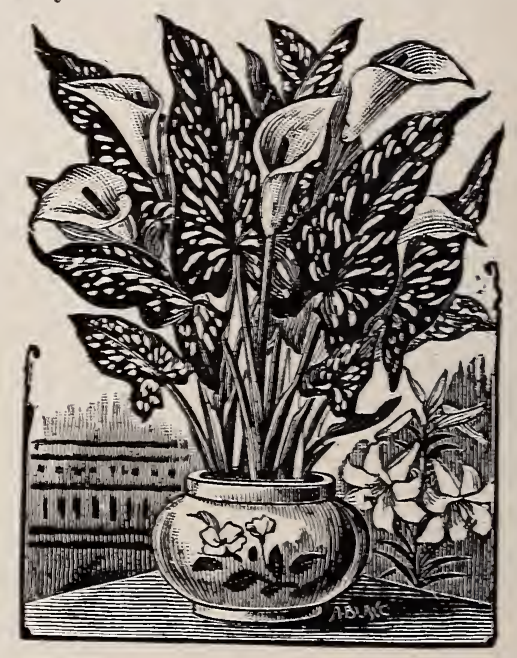

THE LEMON GIANT.

Another Burbank wonder. ^ LiTtLeaEM-Very dwarf, cute Leaves beautifully spotted, frelittle waxy white flowers. Nice pot quently $18 \mathrm{in}$. long, $1 \mathrm{ft}$. wide; an plant. A large pan full of these is a mazing sight. Flowers large, pure beautiful. $10 \mathrm{c}$, 3 for $25 \mathrm{c}$., 15 for $\$ 1$. lemon rellow. Unlike the Golden Note-Callas marked $\boldsymbol{t}$ were potato and makes bulbs 2 feet in first, offered by us in this country. circumstances. $50 \mathrm{c}$., $75 \mathrm{c}$. and $\$ 1.50$. 


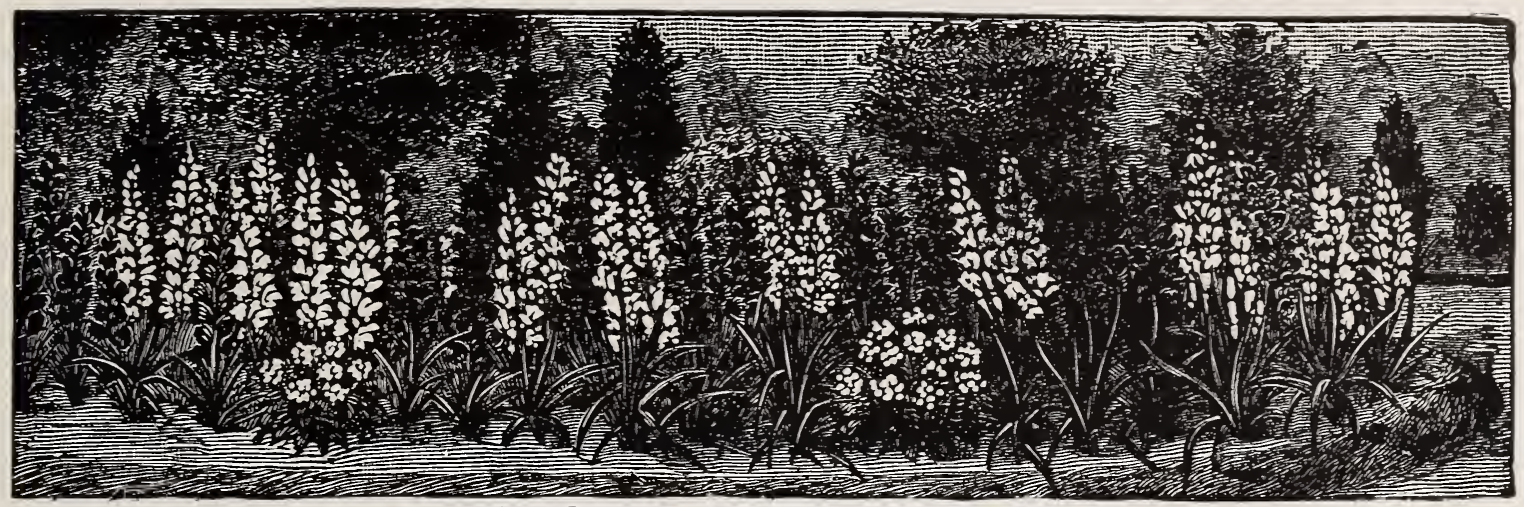

\section{HIGH=CLASS AMERICAN GLADIOLI.}

Our special strain of Gladioli was originated by Doctor W. Van Fleet. editor of the Rural New Yorker, who is one of the ablest authorities on Gladioli in this country, having grown all the known species and varieties. We offer these Gladioli with the assurance that they will prove equal or superior to most of the lighest priced named sorts, most of which have degenerated considerably of late years. These Gladioli have new blood in them. They are healthy, strong, and vigorous, and even small bulbs bloom surely the first year. They combine all colors of the rainbow. The spikes are large and well filled with flowers, and nothing could be more gorgeous than a large bed of them when in bloom. Price of Bulbs, sure to bloom, Io for 25c.; 20 for $50 \mathrm{c}$; 50 for $\$ \mathbf{I . 0 0 ;} 100$ for $\$ \mathbf{I . 7 5}$. Postpaid.

A GOOD GLADIOLUS MIXTURE. Such as offered by the trade in general. Nice bulbs of blooming size, 10 for 15 c.; 25 for 30c.; 50 for $60 c$.; 100 for $\$ 1.00$. Postpaid.

$\$ 5000$ A YEAR !! GLADIOLUS BRENCHLEYENSIS. These frequently multiply at the rate of 200 bulbs per bulb in one year!! Just think of this and calculate the enormous quantities of bulbs you could have in a few years-even at the rate of 25 bulbs per bulb the increase in six years would amount to nearly seven million bulbs. The color is the brightest and purest of all the reds-fine, full spike always in great demand by florists. Price, 10 for $15 \mathrm{c}$.; 25 for $30 \mathrm{c}$.; 50 for $60 \mathrm{coc}$; 100 for $\$ 1.00 ; 500$ for $\$ 4.50 ; 1000$ for $\$ 8.00$. By mail or express prepaid.

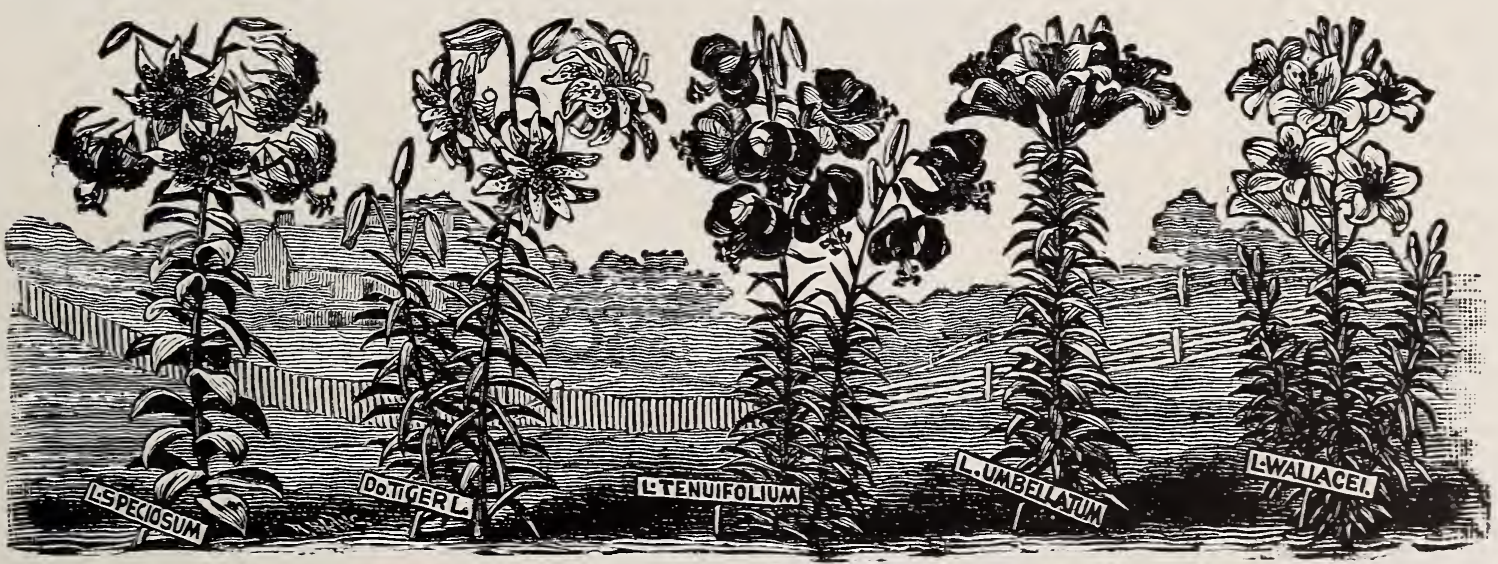

AMERICAN, JAPANESE AND HIMALAYAN LILIES.

\section{Lilium Auratum (Golden Banded Lily).-} Flowers, often one foot across. Spotted with pink and gold.

Lilium Candidum.-Beautiful, large, purest white flowors. One of the easiest to grow and bloom. Lilium Elegans.-Fine, bell-shaped flowers, in dense clusters, of a deep crimson-scarlet color.

'Lilium Longiflorum (Easter Lily).-A profuse and early bloomer. Pure white, sweet flowers.

Lilium Pardalinum.-Combination of red and golden yellow, petals being tipped with crimson.
Lilium Splendens (Leopoldi) - A most magnificent flower of large size. Pure scarlet. Very distinct. Lilium Speciosum Roseum.-White, shaded, and spotted with deep rose and carmine. Very sweet. Lilium Tigrinum.-Perfectly hardy. Certainly a very fine garden plant. Flowers, orange yellow.

Lilium Tigrinum, fi. pl.-The double-flowered sort of the Tiger Lily. Very beautiful. Quite distinct. Lilium Úmbellatum.-Produced in dense clusters or umbels. Colors-yellow, pink and orange. All lilies at 10 cents each; 12 , of our choice, for $\$ 1$. 


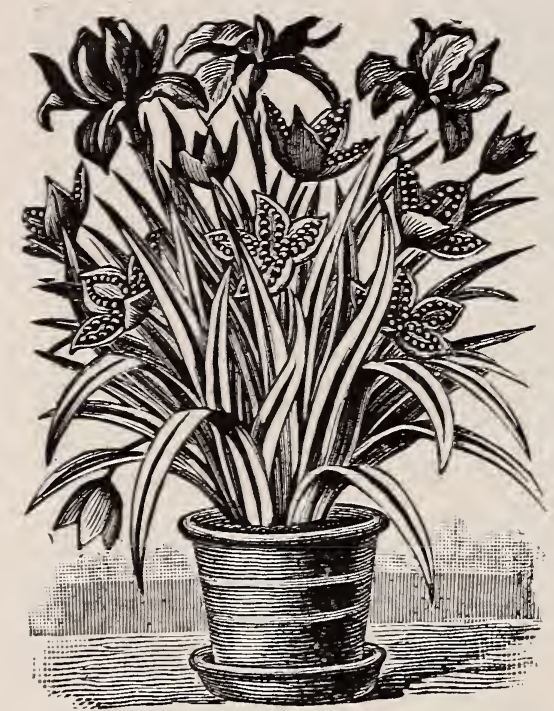

VARIEGATED GLADWIN.
EUCOMIS REGIA.

Royal Crown.
A bulb of noble growth. Foliage large a nd highly ornamental. brown; crowded with hundreds of 235 .

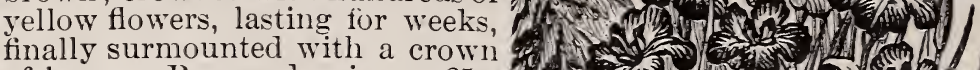
of leaves. Rare and unique. $25 \mathrm{c}$.

\section{THE FLEUR=DE=LIS.}

The Florentine Iris or Fragrant Orris root bears large pure white flowers in great abundance. This is the true Fleur-de-Lis. 15c., 3 for $25 \mathrm{c}$.

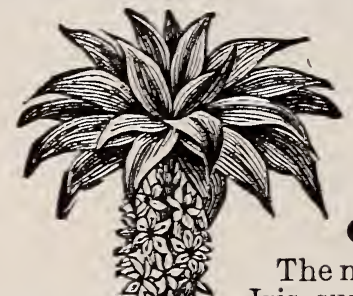

GERMAN and JAPANESE IRIS.

The magnificence of the German and Japanese flowers are enormous -6 in. to $1 \mathrm{ft}$. across. Hundreds upon hundreds of colors and combinations of colors are to be found among them. Any one having a garden should plant them in quantity. Are hardy and need plenty water.

JAPANESE IRIS.

Immense and gorgeous flowers : indescribable array of colors; produced in immense profusion. Clumps of either sort, sure to bloom, 10c., 3 for $25 \mathrm{c}$.

BUTTERFLY LILY.

Hedychuim Coronarium.

Made popular by us some years ago is now admitted one of the finest sweet scented white flowers in existence. See cut below. 15c.

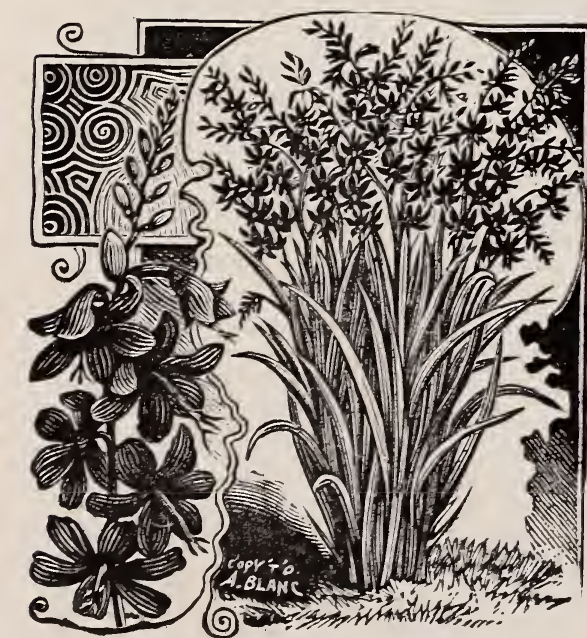

Montbretias-Blazing Stars.

Eucomis Regia. (Royal Crown.)

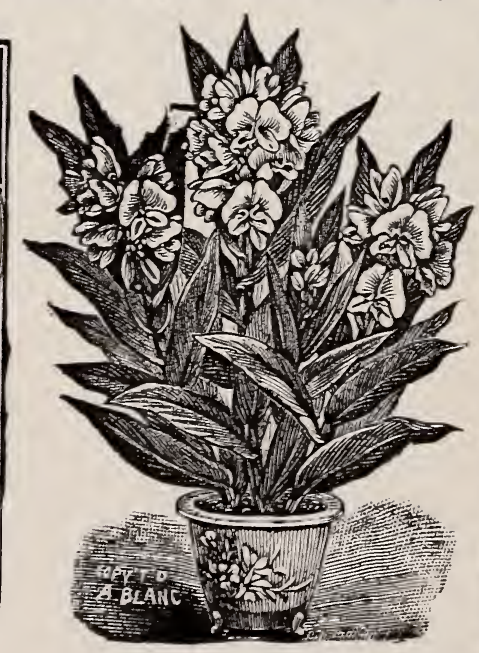

Butterfly Lily.

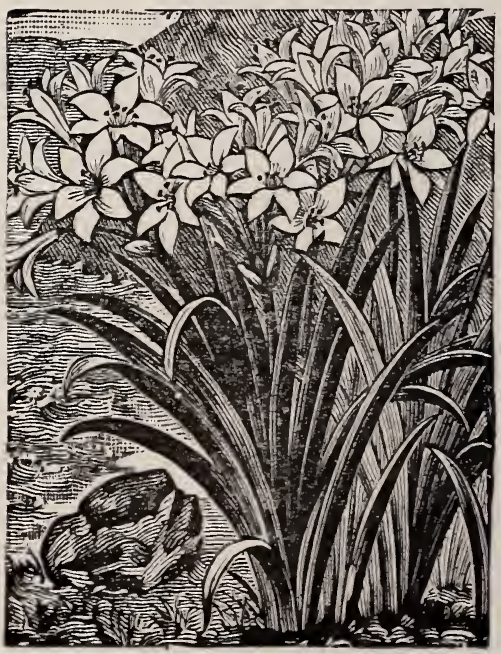

Sea Daffodil. 


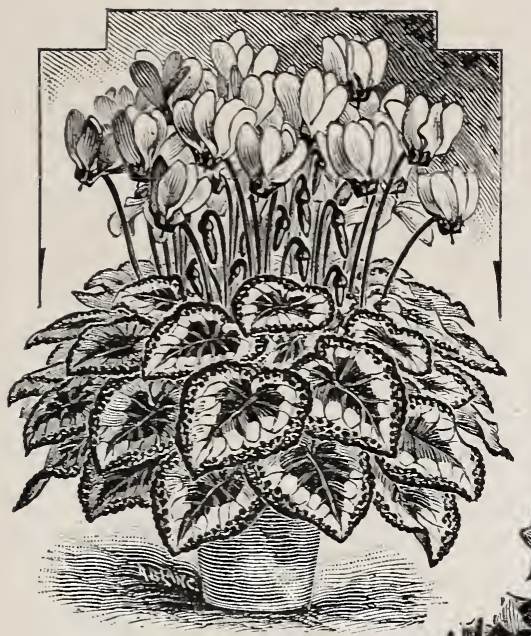

GIANT GLOXINIAS.

These gorgeous flowers are becoming more popular from year to rear. Specimens laden with dozens of immense waxlike flowers of all shades and combinations of colors imaginable are very easily raised from our improved strain of Belgian bulbs. You will really be surprised at their beauty. 10 cts. ; 3 for 25 cts. ; very large bulbs, 20 cts. An excellent flower. SCILLA CLUSI. - Forms large panicles of lilac and blue flowers.

Persian Cyclamen.

\section{PERSIAN CYCLAMEN.}

Our engraving may appear like an exaggeration, not so, however, we've seen finer specimens than this, completely covered with orchidlike flowers airily poised above the beautifully marbled leathery leaves. The colors range from pearly white to darkest crimson, some tipped with red; finest room plants. Very pretty. $15 \mathrm{cts}$. to $50 \mathrm{cts}$.
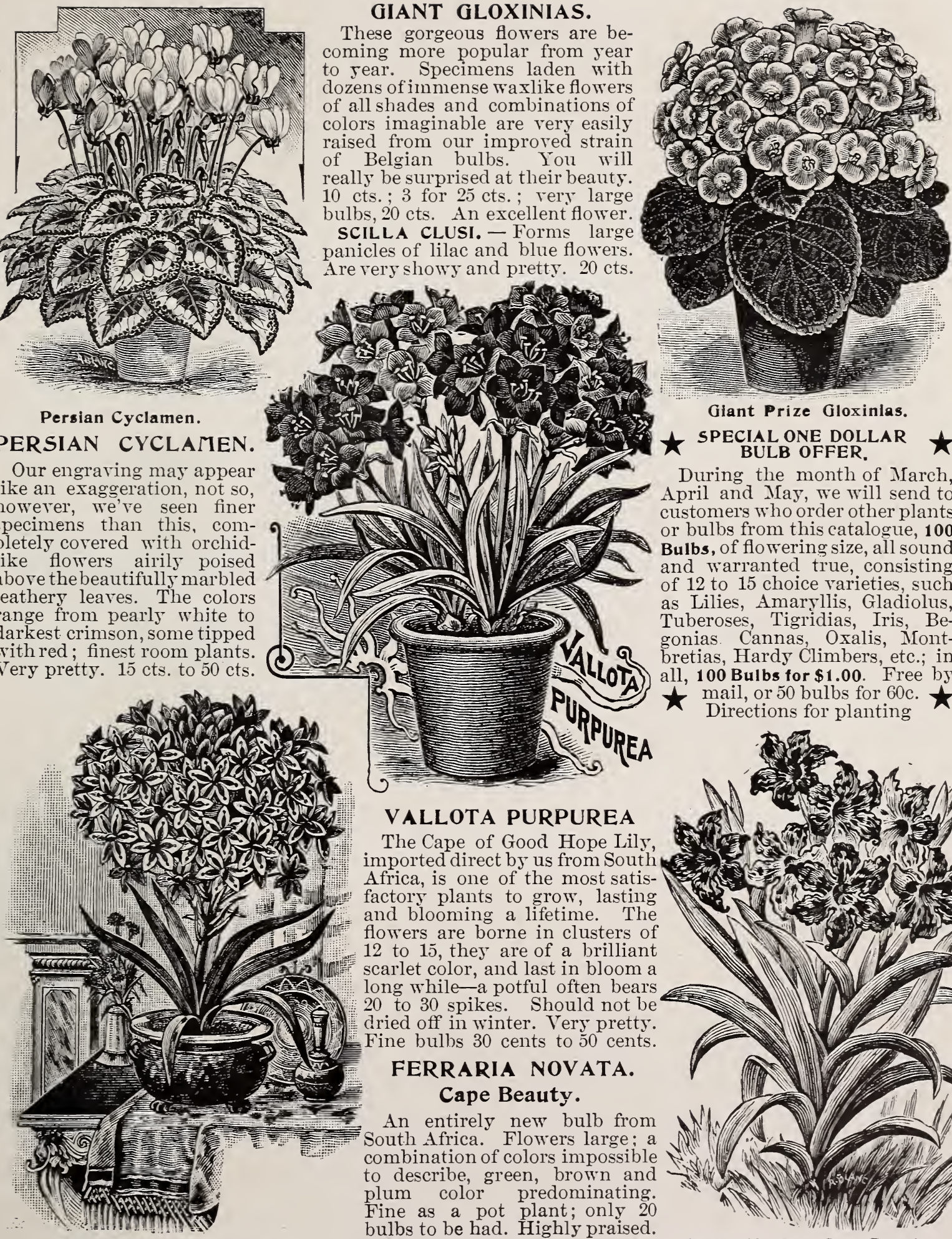

Giant Prize Gloxinlas.

\section{† SPECIAL ONE DOLLAR}

During the month of March, April and May, we will send to customers who order other plants or bulbs from this catalogue, 100

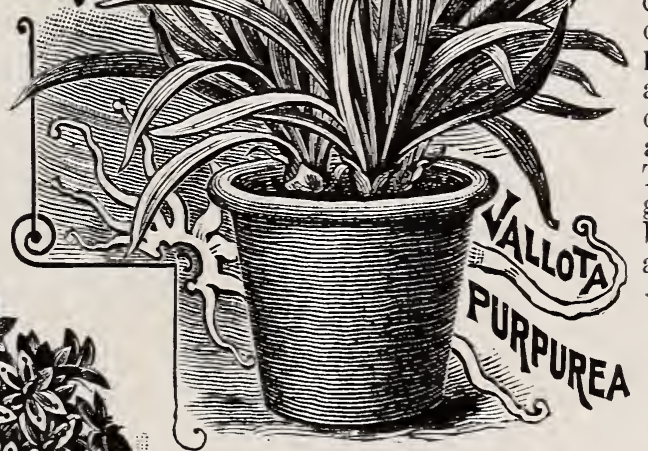

VALLOTA PURPUREA

The Cape of Good Hope Lily, imported direct by us from South Africa, is one of the most satisfactory plants to grow, lasting and blooming a lifetime. The flowers are borne in clusters of 12 to 15 , they are of a brilliant scarlet color, and last in bloom a long while-a potful often bears 20 to 30 spikes. Should not be Fine bulbs 30 cents to 50 cents.

\section{FERRARIA NOVATA. Cape Beauty.}

An entirely new bulb from South Africa. Flowers large; a combination of colors impossible to describe, green, brown and plum color predominating. Fine as a pot plant; only 20 bulbs to be had. Highly praised. Scilla Clusi (Peruvian Lily). An excellent flower. 30 cents.

and warranted true, consisting of 12 to 15 choice varieties, such as Lilies, Amaryllis, Gladiolus, Tuberoses, Tigridias, Iris, Begonias. Cannas, Oxalis, Montbretias, Hardy Climbers, etc.; in all, 100 Bulbs for $\$ 1.00$. Free by $\star$ mail, or 50 bulbs for $60 \mathrm{c}$. $九$

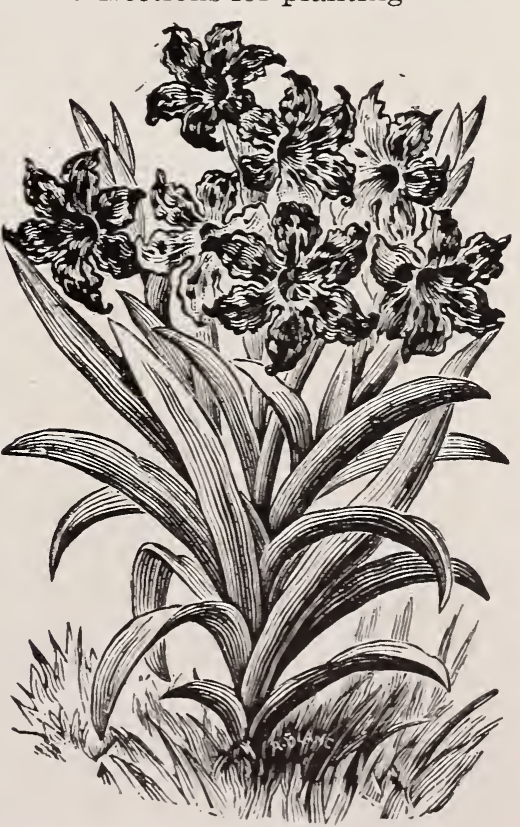

Ferrari Novata-Cape Beauty. 

culture, producing a more vigorous and rapid root action-just what is wanted in plant culture. Nearly all plants do well in Jadoo. Transplanted in Jadoo plants do not flag. It increases size, brilliancy and intensity of color in flowers. It enlarges the leaves, and keeps them a bright green. Seeds germinate in it more quickly than in earth. Cuttings of all kinds root in half the time. Exhausted plants revive in it. Jadoo is cleaner to handle than soil. It is only half as heavy It requires much less watering. quently. It is proof against the inleast, slugs, worms and insects can-

Above are the broad claims

\section{JADOO}

A Magic Plant Grower. as soil. Smaller pots can be used. Plants require repotting less fretroduction of weeds. Last, but not not live in it.

made for Jadoo by the originators. We have used three tons of it within the last three months, and have found it of great value. We can recommend it. Mixed with one-half its bulk of soil, it is very efficacious.

Price of Jadoo.-As the postage on Jadoo is 16 cents per pound, mailing is too expensive; yet we will mail one pound with any plant or bulb order for 25 cents, or we will send hy freight or express, 5 pounds for 30 cents, 10 pounds for 50 cents, 25 pounds for $\$ 1.10$, at purchasers expense.

SPECIAL OFFER.-Five pounds of Jadoo,
enough for Ioo pots, I2 three=inch paper flower
pots, I2 wooden plant labels, all in one box, by
express, for 50 cents. Have your plants sent at
same time, and save 20 per cent. express charges. OUR OWN PLANT FOOD. - We put this up for some of the largest houses in the United States. for plants that need a tonic. Clean is excellent for mixing with the soil, or used as a top dressing 50 cents. If by mail, 16 cents per pound must be added.

PAPER' FLOWER POTS._These are light, clean and useful-last for many months, being made of water-proof paper; excellent for Jadoo. Price, $2 \frac{1}{2}$-inch, at 25 cents per 12 , or $\$ 1.00$ per 100 ; 3-inch, 30 cents per 12 , or $\$ 1.25$ per 100 , mailed.

\section{$\$ 5000$ A YEAR CAN BE MADE WITHOUT TROUBLE.}

\section{0 to 1 Made on Your Investment.}

Do you know that a certain kind of Gladiolus multiplies at the rate of 200 Bulbs to every single bulb every year, and this for every 2 or 3 years in succession! If you will make your own calculations you will easily be convinced of the enormous number of bulbs that can be accumulated in 2, 3 or 4 years! It runs into millions, and you can grow millions on a small piece of ground. This sear the price of common Gladioli runs from $\$ 6$ to $\$ 10$ per 1000 according to size, and large ones are hard to get at any price. The largest growers of the country have none left to sell!

YOU can grow them without experience and derive much pleasure and profit from your investment.

We will mail you 100 of these money=making Gladioli to start with for $\$$ I or $\mathbf{5 0}$ for 60c., 25 for 30c., with full particulars. A. BLANC \& Co., Philadelphia.

\section{)UR ONE DOLLAR "MAY SURPRISE" COLLECTION}

\section{A GREAT SURPRISE IN STORE FOR YOU.}

It is impossible to estimate accurately how many plants of any kind will be sold during a season. In order to be able to fill all orders promptly, we grow a large surplus to meet unexpected demands. At the end of the busy season this surplus must be disposed of, or the plants would become too large for mailing purposes. We give our customers the benefit of this extra stock. Many wait for it every year, knowing that they receive much for little. Towards the 1st and bulbs in a number of one heard-of liberality. You may safetimes the value of your money. get plants worth 50 cents to $\$ 1$ MUCH FOR LITTLE! of May we make up these plants ly expect to receive two or three and need not be surprised if you $\in a c h$. These surprise collections are an advertisement for us. They consist of plants, bulbs, seeds, etc., for the house and garden-many that cannot be had elsewhere. We cannot, however, afford to send them during the rush of business ; but all orders will be filled about the ist of May, or later if desired, and will be postpaid. All orders will be duly acknowledged by return mail, numbered and registered. Orders for $\$ 2,3$, $\$ 5$ or $\$ 10$ filled on the same liberal terms. Be sure to state that you wish a Surprise Collection. 


\section{Curious Japanese Fern Balls}

When we first offeled these Japanese curiosities eren florists rere skeptical about them. They wouldn't take - they wouldn't last-was what they said. To-day, they are fighting for them. One great house who thought they would sell only a hundredordered one thousand more of us. And a large department house in New York is said to have ordered 10,000 ! As to their lasting greatly, look at the fine specimen shown here. It is 3 rears old and improring in beauty erely day. These balls are

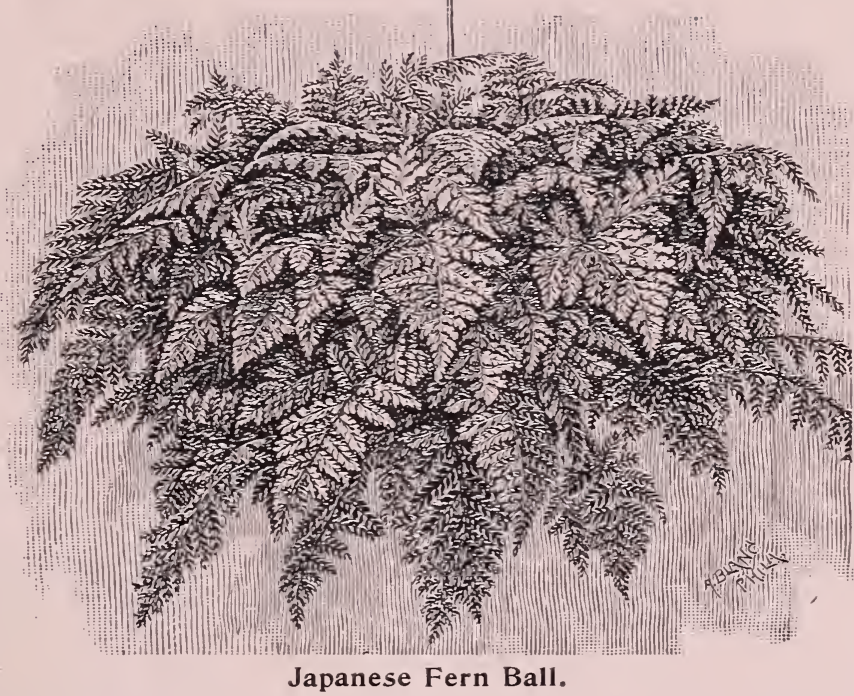

bright green fronds. They look beautiful suspended from chancleliers, in window: doors, or on rerandas, and can be used in very many ways. They are very hardy and will stand drought for many weeks, but to have them at their best, sliould be kept moist at all timesthen the whole surface becomes corered with fresh green live moss, lichens and other little gems. Never have we introduced anvtling which has been so m uch admired. To stale the balls in growth quickly, it is best to keep them for formed of a mass of roots of the hardy Japanese a while in a bowl or dish half filled with water in a fern called Darallia, tied around peat and moss: light place. When well filled with green fronds with age the roots rum in every direction over they can be hung where wanted. Prices, $\mathbf{7 5 c}$. $\mathbf{\$ 1 .}$ the moss, their soung growth producing the and up to $\$ \mathbf{5}$. By mail or expiess, pieprirl.

\section{$\downarrow$ APERA ARUNDINACEA} " Silver Fountain Grass."

Ah, now! There is something pretty. That's the general exclamation. And so it is, indeed. so entirely new that you won't eren find it in the latest dictionary of gardening. We re had a time to get the seed, fresh from the dense forest of New Zealand, after 3 years' waiting. The only plant we ever heard of, was exhibited at a meeting of the Royal Horticultural Society and illustrated in the Gardeners' Chronicle as shown herewith. While it is hardy and would produce a fine effect on rockeries, one can see how much more beautiful it is as a pot plant, the long silvery flower spikes drooping way below the pot in sparkling featherr sprars, 3 feet across. It will no doubt rival Asparagus Sprengeri, which we made so popular that a million plants were grown last year. As our seed came late we can at present offer only small tufts at $30 \mathrm{c}$., but it comes up so quickly that rou can get a lot from a packet of seed at $15 \mathrm{c}$. It is very choice.

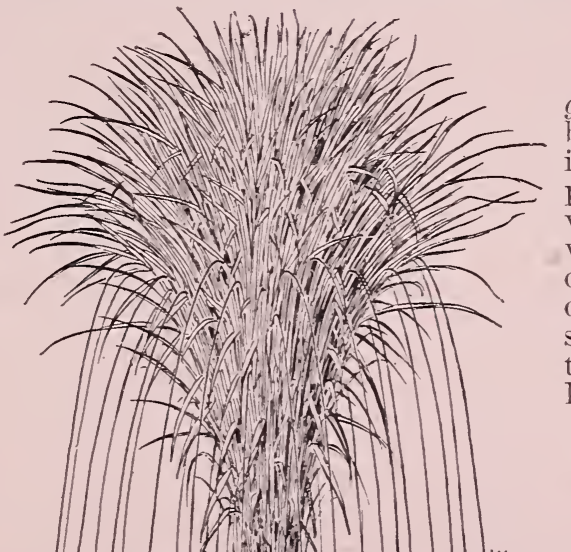

\$100 FOR ONE PLANT!

Seedlings of Asparagus sprengeri vary considerably and many beautiful new forms are now being multiplied. We raised one plant which was almost pure white and sold it for $\$ 100$ to a well-known English firm. One of our customers raised a very dwarf compact sort, for the stock of which he declines $\$ 200$ to-day. You may be just as lucky. Try it. Seed $10 \mathrm{c}$. per pkt.

\section{$\$ 50$ FOR YOU!}

$\downarrow$ THE NEW FRINGED ZINNIA

A Grand Novelty.

The seed of this great novelty is sent out this year at the price of $\$ \mathbf{5 0}$ per ounce! The flowers are an entire departure from anrthing known heretofore in Zimmins, the flowers being scalloped, fringed and laciniated. The only color su far produced is a pure wlite, but the originators claim that some new colors will surely be produced, and we offer a prize of $\$ 50$ for the plant showng the brightest color with fringed petals; 820 for $2 \mathrm{~d}$ best; 310 for $3 \mathrm{~d}$ best; 85 for th best. Pri plit. 1.5. 


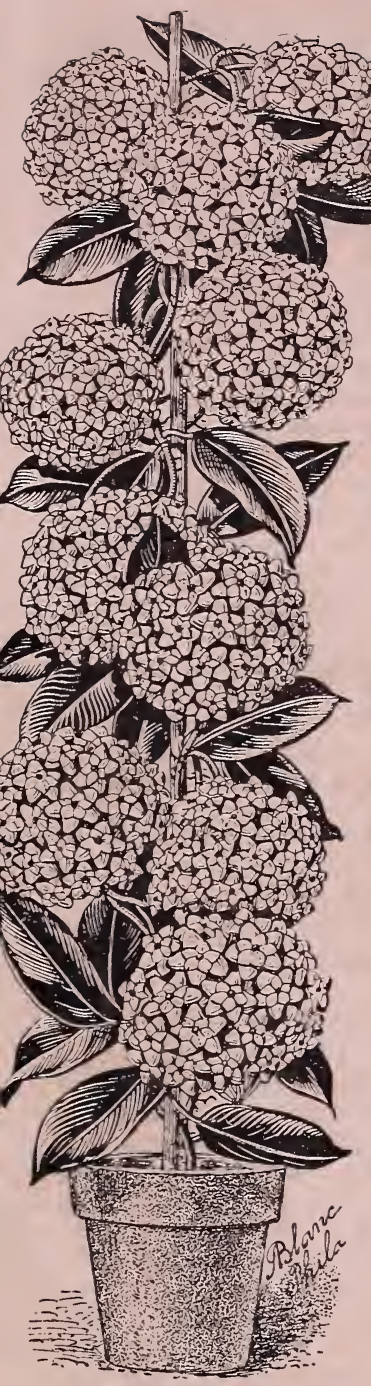

A NEW WAX PLANT HOYA GLOBULOSA.

Every one admires the old Wax Plant, and why not, it is one of the Wonders of nature. new sort is far superior in every way. Note the immense balls of flowers, so perfect as to appear artificial, even drops of honey nestle on their star-shaped form, and, although their profusing seems to be beyond belief, we've seen specimens even finer. Unlike the old wax plant this blooms continuously. Lasts a life time. Young plants $50 \mathrm{c}$; the old Hoya Carnosa $25 \mathrm{c}$.

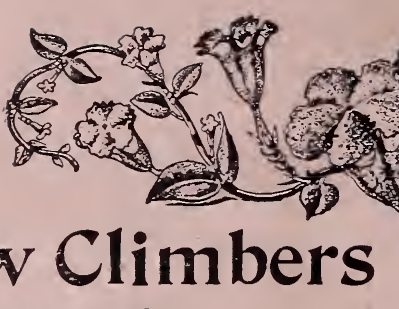

\section{THE NEW TREASURE VINE.}

An entirely new plant recently discovered in the mountains of Costa Rica and named Childsia Werckleyi. As may be seen from our illustration, the flowers are most beautiful in form, and it might well be called an Orange Flowered Clematis. There is in fact not another climbing plant in existence approaching it in color, which is a clear orange scarlet. It can be grown indoors or in the garden and will prove a great source of delight. Price 25c.

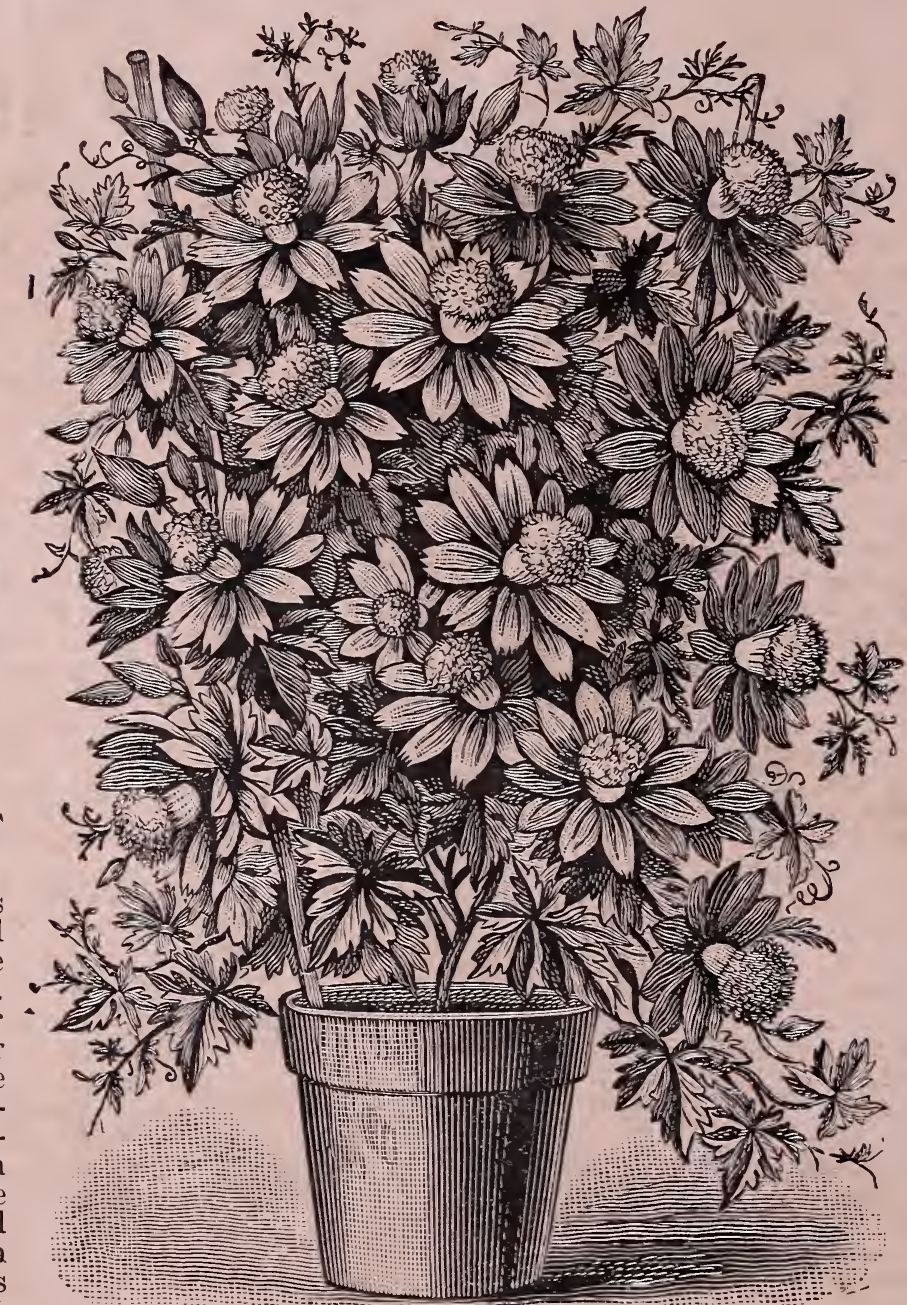

Childsia Werckleyi. (Treasure Vine.)

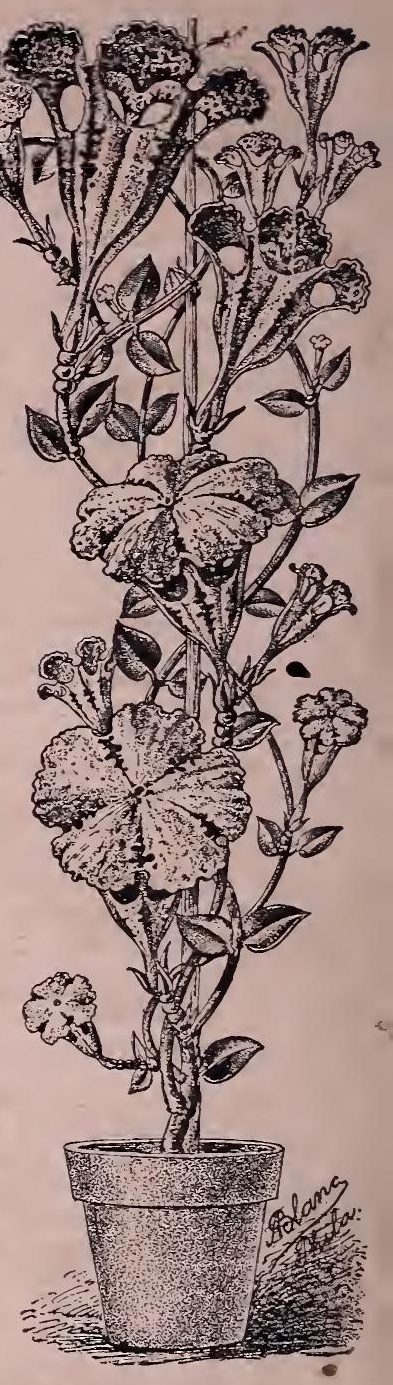

Parachute Flower. (New)

Look at it. Isn't it odd and beautiful; something the flower crank raves over and of which he scarcely credits the accuracy of the picture. We've been 5 years trying to get a few plants of this and have but few indeed. They'll go off quickly, too, though the price nay seem high. It is a slender Hleshy climber, growing the whole year. Needs rich peaty soil, lots of water. Flowers are a curious buff, spotted and splashed with yellow: maroon and blood-red. $60 \mathrm{c}$. 